\title{
Looking back, looking forward: a review of the new literature on diatom teratological forms (2010-2020)
}

\author{
Elisa Falasco 1 - Luc Ector • Carlos E. Wetzel • Guido Badino • \\ Francesca Bona
}

Received: 7 August 2020/Revised: 4 November 2020/Accepted: 2 February 2021 / Published online: 4 March 2021

(C) The Author(s) 2021

\begin{abstract}
Over the last years, issues concerning diatom teratological forms and environmental stress have received growing interest within the scientific community. Publications on this topic dated back to 1890 and were summarized in a review published in 2009 by the journal Hydrobiologia, accounting for high citation rates (i.e. 117 citations Scopus and 232 citations Google Scholar, October 2020). This wide interest stimulates the authors to further unravel teratological forms significance in the light of the most recent publications (2010-2020). Diatom teratological forms are one of the best individual-level biomarkers since they provide a rapid response to several environmental stressors, including new
\end{abstract}

Handling editor: Judit Padisák

Supplementary Information The online version of this article (https://doi.org/10.1007/s10750-021-04540-x) contains supplementary material, which is available to authorized users.

E. Falasco $(\bowtie) \cdot$ G. Badino · F. Bona

DBIOS, University of Turin, Via Accademia Albertina 13,

10123 Turin, Italy

e-mail: elisa.falasco@unito.it

E. Falasco - F. Bona

ALPSTREAM, Alpine Stream Research Center,

12030 Ostana, Italy

L. Ector · C. E. Wetzel

Environmental Research and Innovation Department (ERIN), LIST, 41 rue du Brill, 4422 Belvaux,

Luxembourg emerging pollutants. The mechanisms involved in teratological valve likely involve both cytoskeleton and silicon metabolic pathway impairments. However, teratologies do not seem to weaken the reproduction capacity and viability of the affected individuals. We recognized eight types of teratologies as involving different parts of the valve, depending on genus. In order to summarize the information obtained by several years of research, we suggest a four-step procedure aimed at providing a theoretical pathway that researchers should follow to better explain results obtained in next-future studies and representing a starting point for the development of an environmental index based on teratological forms.

Keywords Bacillariophyceae - Biomarkers · Environmental index · Freshwater diatoms · Trace metal contamination - Teratology

\section{Introduction}

In recent years, diatomists have been more and more involved in the research of reliable and easily applicable tools for the environmental contamination assessment in freshwater ecosystems (Morin et al., 2012a). Indeed, due to their short generation times and fast growth, diatoms allow the detection of complex phenomena on a small-scale time, if compared to higher organization levels (Morin et al., 2015). 
Among biomarkers, the responses at the individual level are known to be the most effective early warning systems. In this context, diatom teratologies reflect the sub-lethal responses to the environmental stresses and represent an important compromise between response sensitivity and ecosystem relevance, since alterations at the individual level of organization still represent an early end-point. The rapid response to the contamination (generally 1 week) allows recovery in the ecosystem health status, before the following organization levels (such as population, community and food chain) will be affected. Moreover, the record of the teratologies can be easily included in the routine diatom sample analysis with no further efforts, fulfilling the requests of limiting time and resources during the biomonitoring procedure (Lavoie et al., 2017).

Starting from these considerations and strongly believing in diatom teratological form potential in 2009, we published a literature review on this topic, with the aim to shed light on the enormous amount of literature concerning teratological form production and environmental stresses (Falasco et al., 2009a). In that work, 222 papers were cited and, in turn, our paper stimulated the scientific community to improve its knowledge on this topic and received great attention, as underlined by the high number of citations, i.e. 117 (source Scopus, October 2020) and 232 (Google Scholar, October 2020).

Why it is still important to study teratological forms for monitoring purposes?

Presently, there is still a wide debate about the most appropriate indicators of response to environmental stress in aquatic environments. Recent studies have highlighted the limitations of some metrics commonly used for detecting the effects of pollutants.

In the framework of the river ecosystem assessment, biomass metrics such as chlorophyll $a$ or diatom density often display confusing patterns and their responses frequently result unrelated to the contamination levels. In some cases, chlorophyll $a$ decreased after trace metal exposure (Pandey \& Bergey, 2018; Pandey, 2020), in other cases no variation was recorded (Licursi \& Gómez, 2013), in others fluctuations were observed (Mu et al., 2018), sometimes chlorophyll $a$ even increased after a contamination event (Mu et al., 2017). Diatom density and chlorophyll $a$ are strictly dependent on many biotic and abiotic interactions and, for this reason, they have been often criticized when used for contamination assessments (Pandey et al., 2017). Indeed, as these two metrics are easily influenced by the presence of tolerant species [such as Eolimna minima (Grunow) Lange-Bertalot], a disproportional growth of small adnate taxa with high reproductive rates after a contamination is often observed, with a consequent cell density increase and community biovolume decrease (Arini et al., 2012a, c). For this reason, in many cases biovolume would be a more reliable metric to consider than cell density; however, its estimation is time consuming (Pandey et al., 2017). Moreover, Kim Tiam et al. (2018) also observed that chlorophyll fluorescence could be affected by the presence of certain contaminants (such as herbicides or zinc), leading to misrepresented results.

In the same way, diversity-related metrics do not always show consistent responses to the contamination, in part due to the Intermediate Disturbance Hypothesis (Wilkinson, 1999), in part because different diversity indices provide different types of information (Pandey et al., 2017). Notwithstanding, some authors detected a decrease in species richness and Shannon diversity after trace metal exposure with stronger effects of copper $(\mathrm{Cu})$ than zinc $(\mathrm{Zn}$; Pandey \& Bergey, 2018).

At cellular level, antioxidant enzyme activity measured in the biofilm, and in particular ascorbate peroxidase, demonstrated to be an early toxicity biomarker for $\mathrm{Zn}$, responding even few hours after the contamination event (Bonet et al., 2012). However, changes in the antioxidant enzyme activity have been recently observed also in non-contaminated sites, and associated to the community succession process, calling into question the reliability of this metric in the framework of the pollution assessment (Bonet et al., 2012). Also, the production of lipid bodies in live frustules can be considered as a good marker of trace metal toxicity and recovery. In this context, Pandey \& Bergey (2018) found significantly higher percentages of lipid droplets in diatoms exposed to trace metal contamination, with $\mathrm{Cu}$ resulting more toxic than $\mathrm{Zn}$. The same results were recently obtained by Park et al. (2020) who observed a significant increase in lipid bodies volume in the genera Amphora Ehrenberg ex Kützing and Nitzschia Hassall, as response to $\mathrm{Cu}$ contamination. Another study statistically confirmed a 
positive correlation between trace metal contamination (especially $\mathrm{Pb}$ and $\mathrm{Se}$ ) and lipid bodies production in Gomphonema pseudoaugur Lange-Bertalot, which also resulted as one of the most resistant species in communities exposed to such impairment (Gautam et al., 2017). Again, Antoni et al. (2020) observed bigger lipid bodies in cells treated with $\mathrm{Zn}$ than control ones. Pham (2019) found that silver nanoparticles (AgNPs) increased the total lipid production in Thalassiosira sp. However, the results in literature are not always consistent, as highlighted for instance by Pandey (2020), who recently observed no lipid bodies increase in diatom communities after $\mathrm{Pb}$ exposure.

The present review aims at analysing the progress made on diatom teratological forms during the last 10 years, offering new insights and confirming or denying previously advanced hypotheses. Based on the most recent research literature, we will analyse all those environmental impacts, which lead to the formation of abnormal diatom forms, with a focus on new emerging pollutants. We propose new insights on the mechanisms involved in the normal and abnormal valve cell formation and we will examine new results obtained on the reproduction capacity and viability of the teratological individuals. We will explore the functional responses at community level, taking in consideration diatom class sizes, life forms and ecological guilds. Finally, we propose a four-step procedure that could be used in future research to better interpret the ecological meaning of diatom teratological form's presence in the biofilm.

\section{Methods}

The present paper and the elaborations herein contained focus on research dealing with diatom teratological forms, published from 1890 up to date.

All the information concerning literature published from 1890 to 2009 were mostly contained in our previous research published in Hydrobiologia (Falasco et al., 2009a). From Table 1 of that paper, we extracted data on diatom species, type of deformations and possible causes inducing the production of teratological forms.
In a similar way, we treated data extracted from the most recent literature (i.e. part of 2009 up to present). To do this, we performed a bibliographic research using search engines such as Scopus ${ }^{\circledR}$, Web of Science $^{\mathrm{TM}}$ and Google Scholar. We used the software Publish or Perish ${ }^{\odot}$ (version 7.0, Tarma Software Research Ltd.). All papers containing "diatom*", "terato*", "deform*" and "alter*" in their title/ abstract/full text from 2009 and 2020 were selected and downloaded. The articles were then carefully screened and included if judged relevant. In particular, we excluded (i) papers with no relation whatsoever with diatoms; (ii) papers including the aforementioned words only in the introduction and discussion, but not providing new results. We excluded from the present paper all the information derived from grey literature, as required in the author's guideline of the journal. In particular, during the literature review, we found, but were not included in the analysis: technical reports $(n=39)$; articles on very local journal/in original languages $(n=19)$; bachelor/master theses $(n=17)$; PhD theses $(n=15)$; posters $(n=3)$; power point presentations $(n=3)$; abstracts in book of conferences $(n=1)$.

All the data obtained from this second research were summarized in a table containing a list of the diatom species subject to deformation, the type of teratology and the possible causes inducing it.

These two tables, the first contained in Falasco et al. (2009a) and the second produced in the present paper, were merged. After that, for each species, we added information concerning class size, life form and ecological guilds following Rimet \& Bouchez (2012).

\section{Results and discussion}

In total, we analysed 409 papers, 222 already contained in Falasco et al. (2009a), 187 in the present paper. Of these 409 articles: 185 cited in their text at least one diatom species showing teratologies (about $45 \%$ of the total analysed literature); 154 hypothesized one or more causes leading to the deformations (about $38 \%$ ). In total, from this literature review we were able to obtain a list of 298 taxa, which showed some kind of deformation and the corresponding hypothesized cause. Table 1 summarizes all these information. 


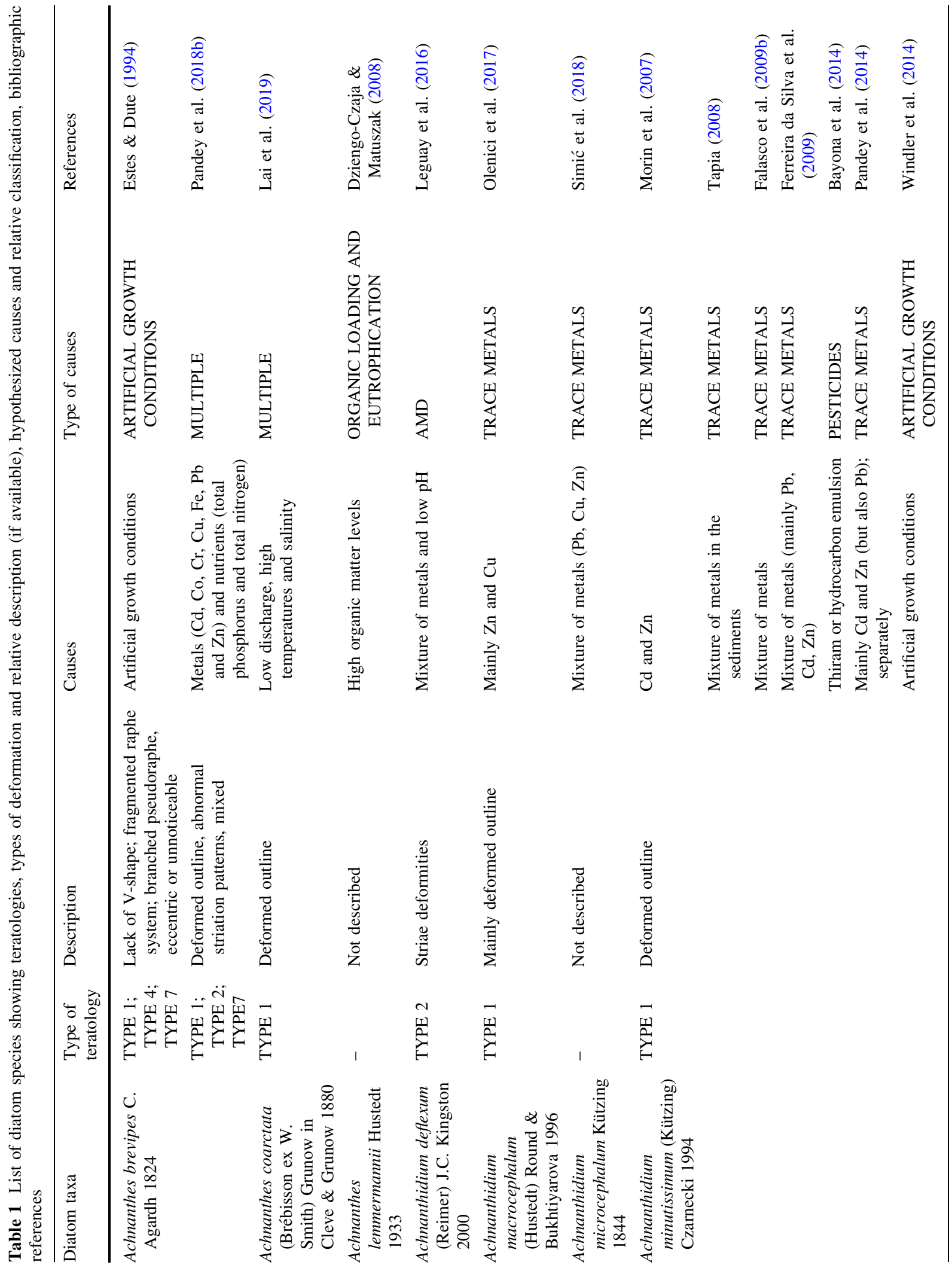




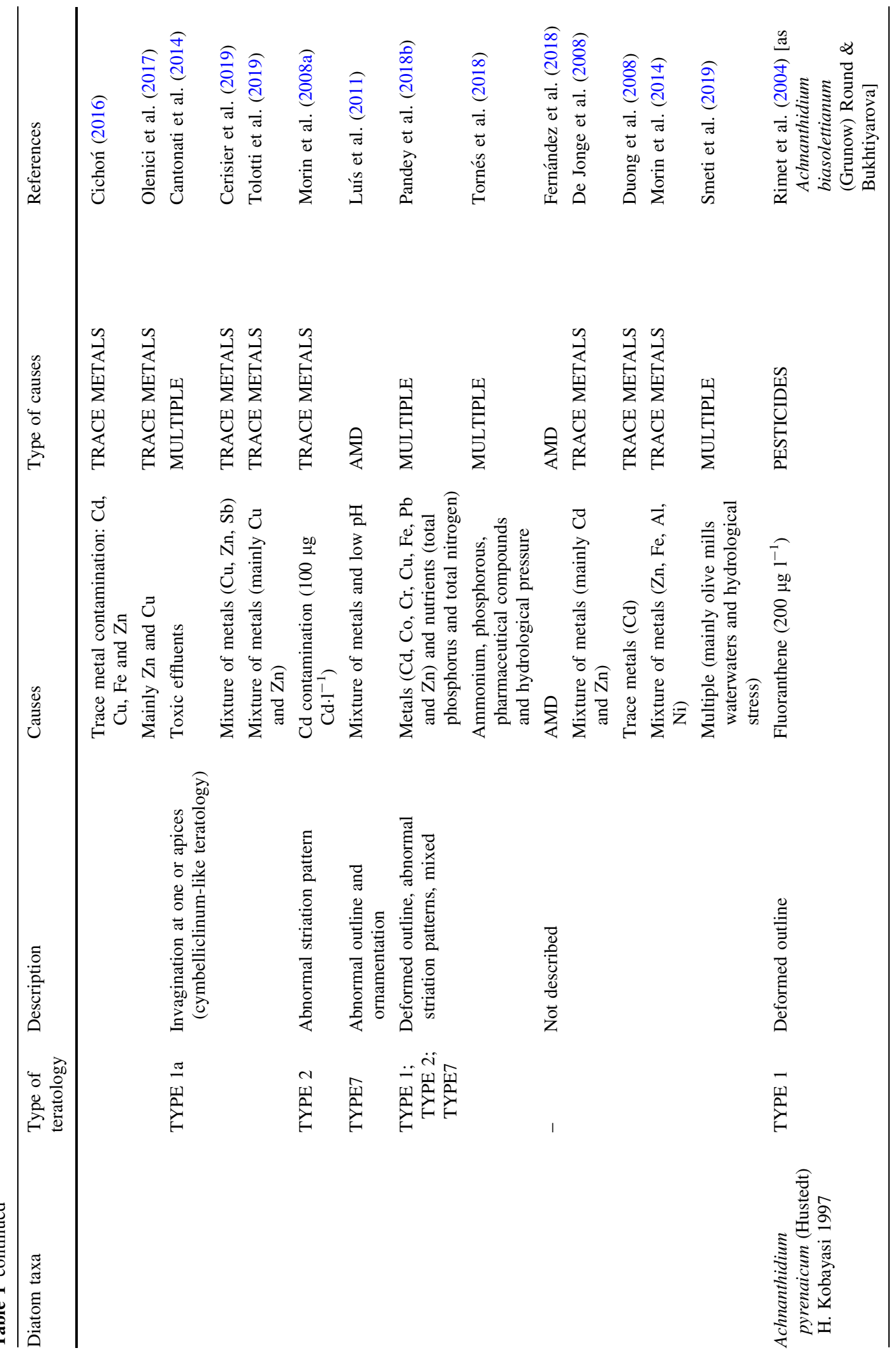




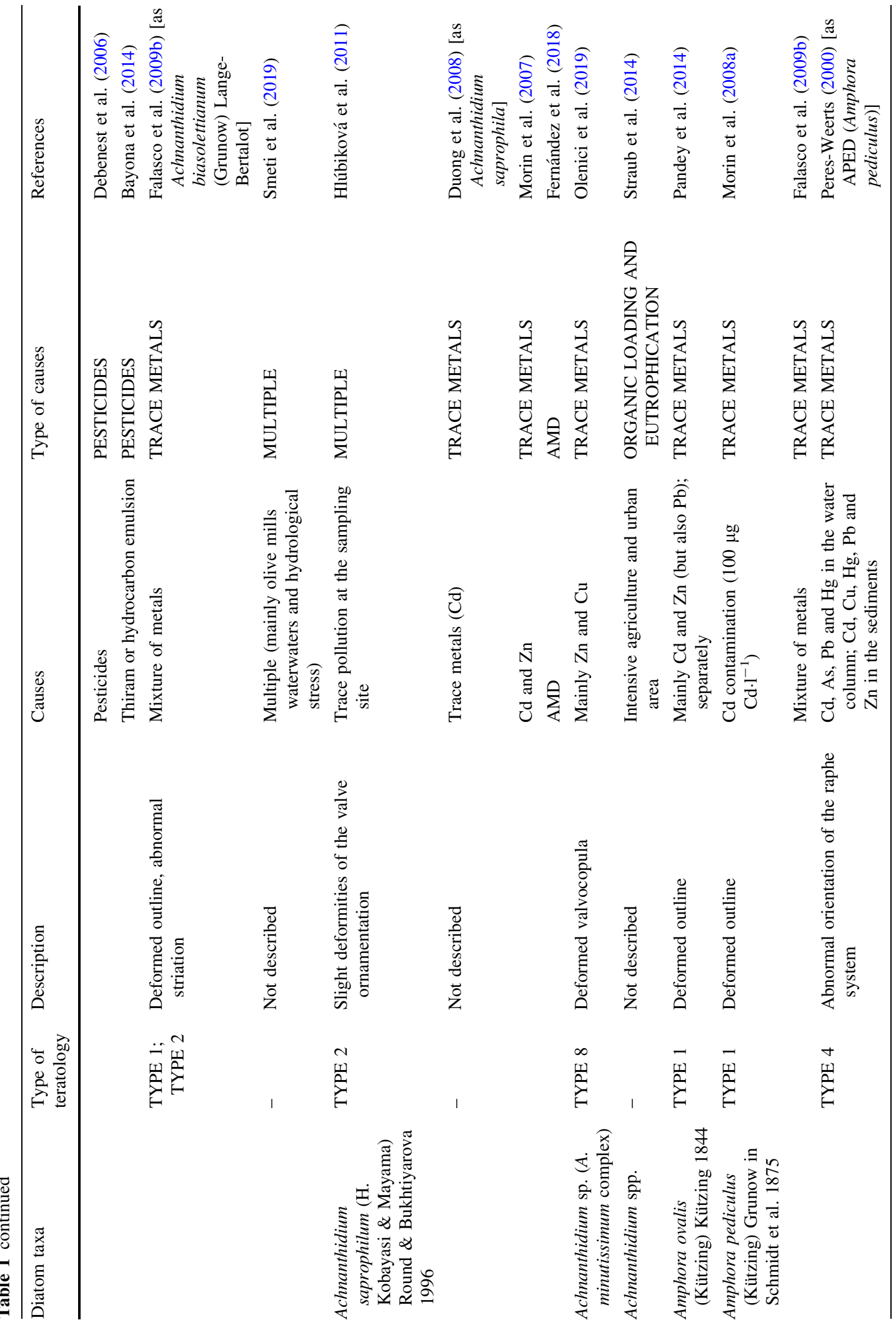




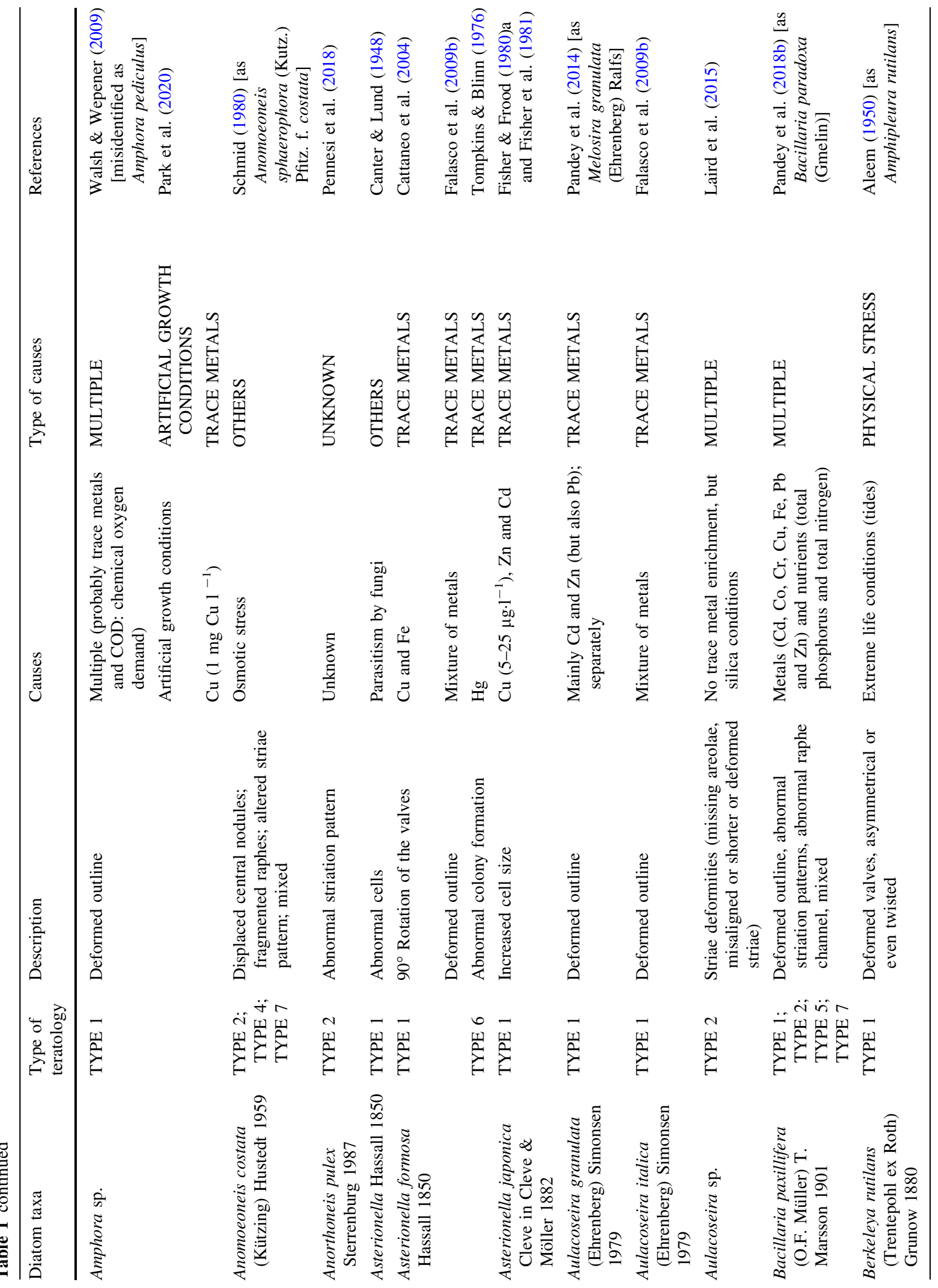




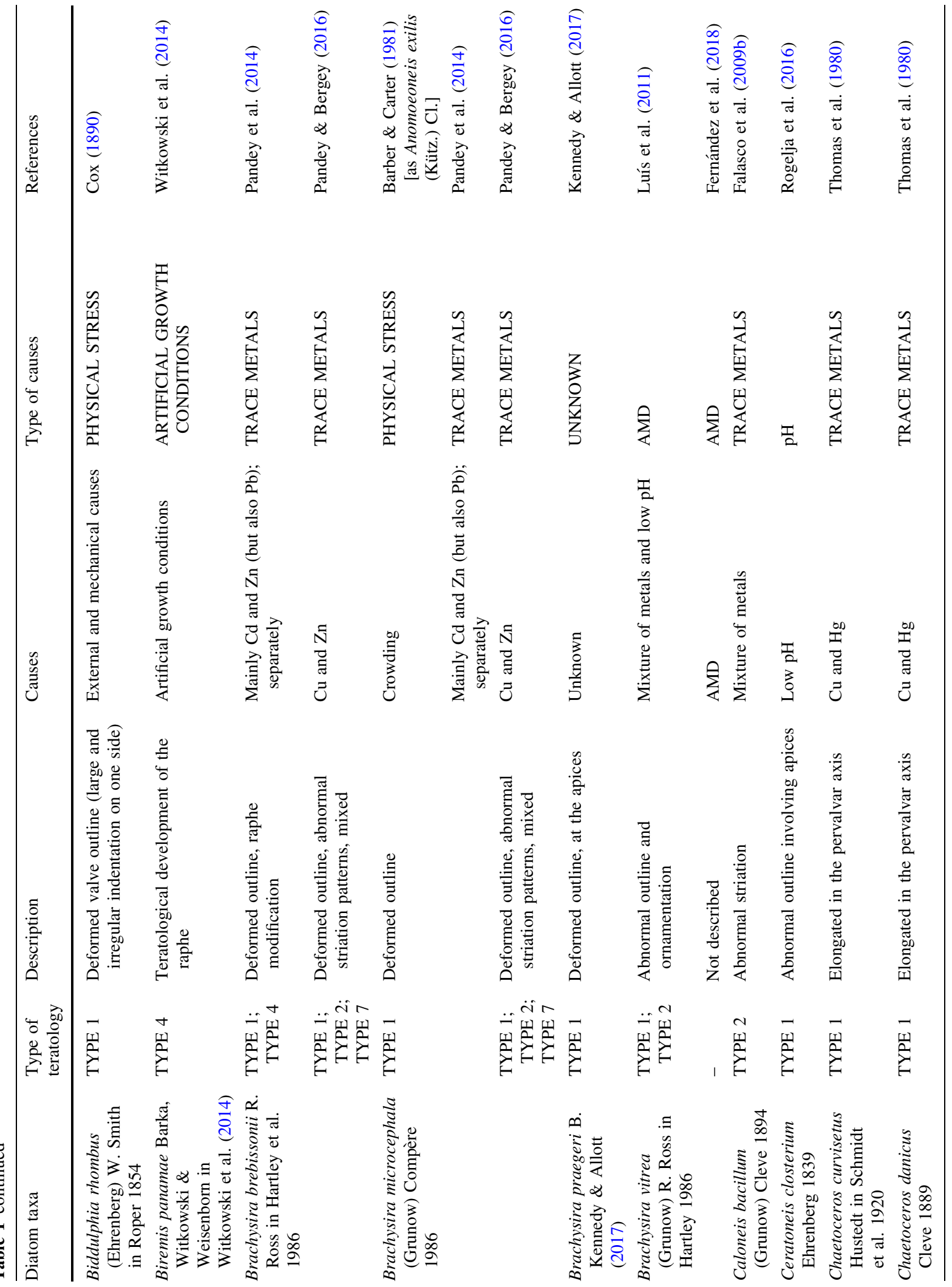




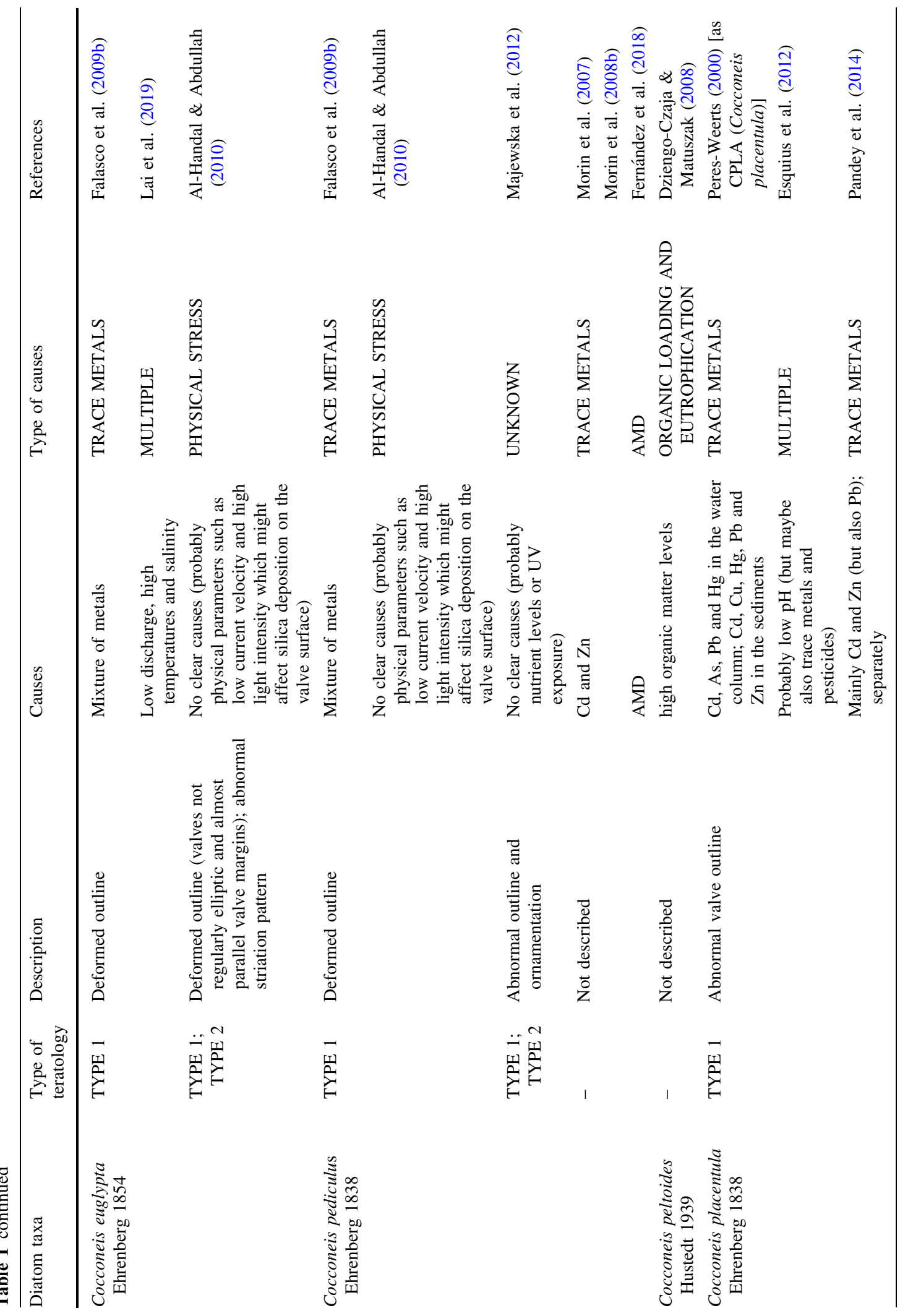




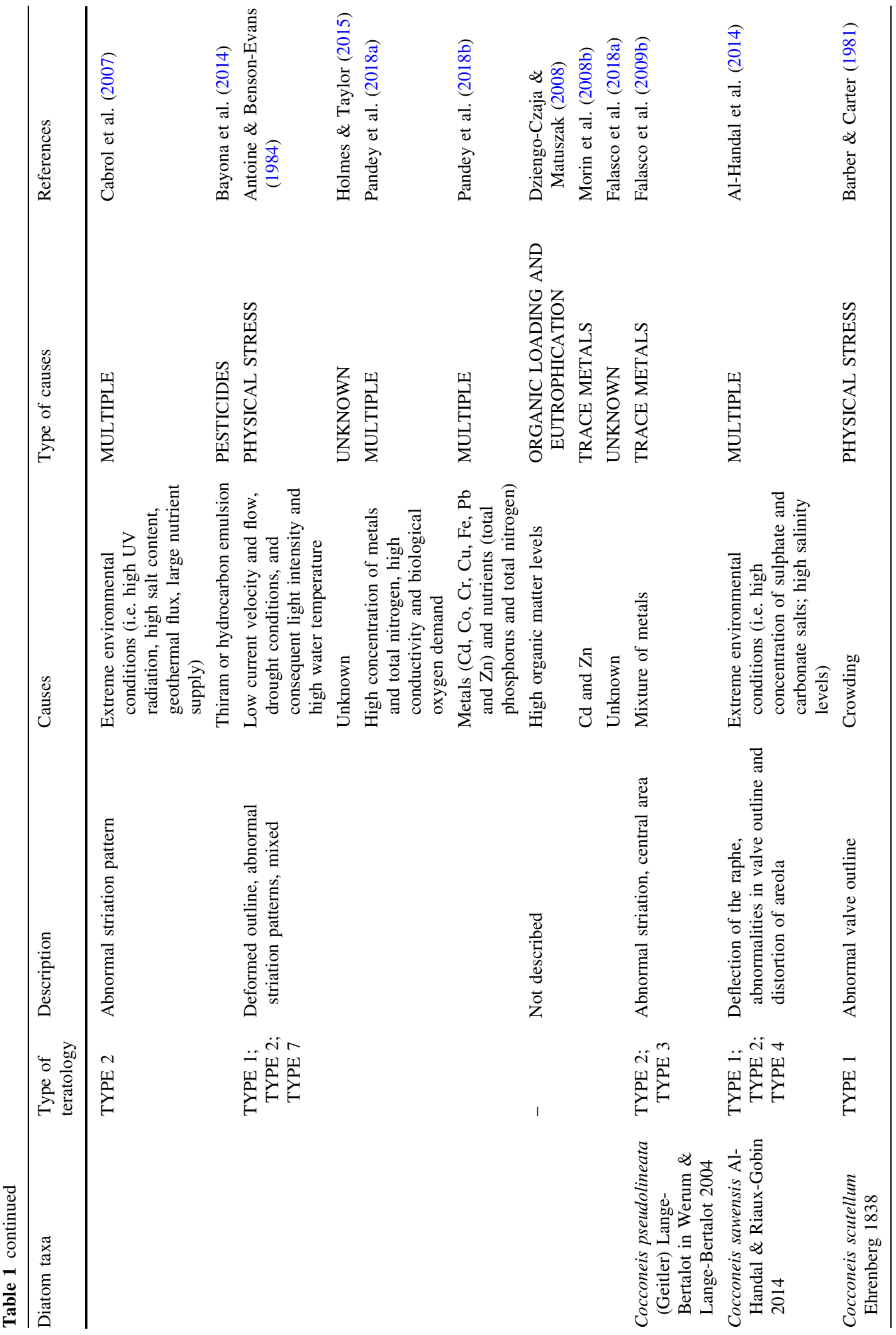




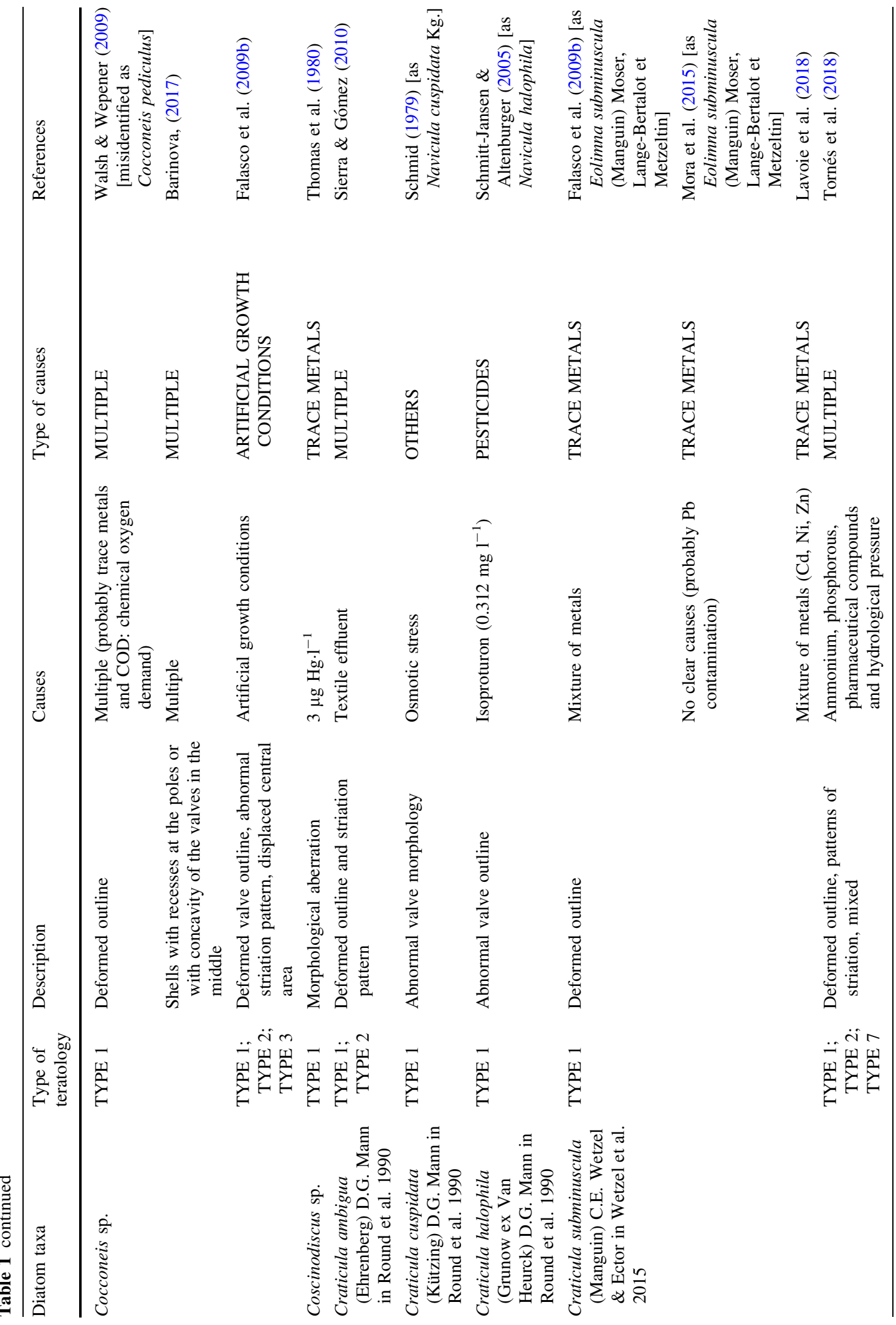




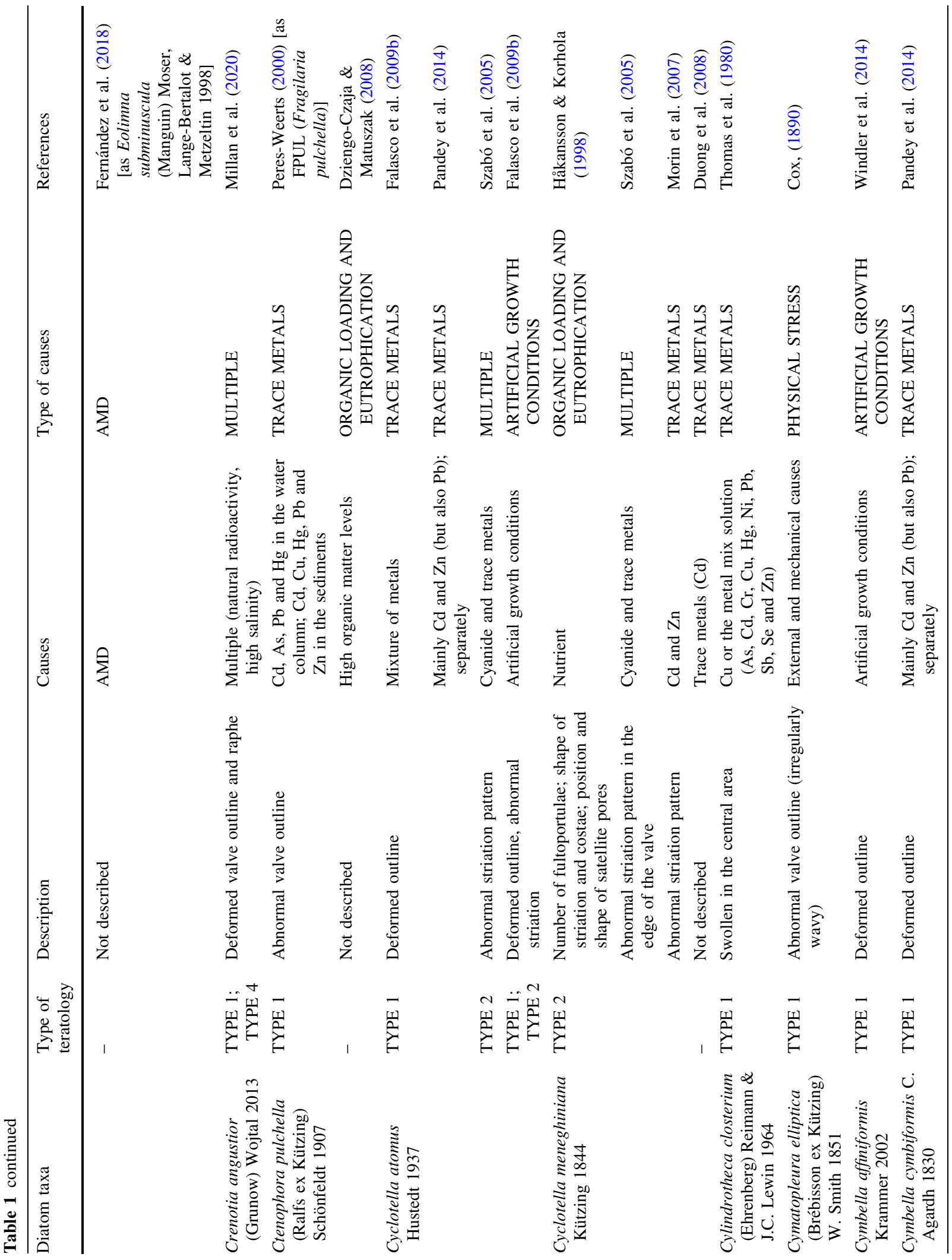




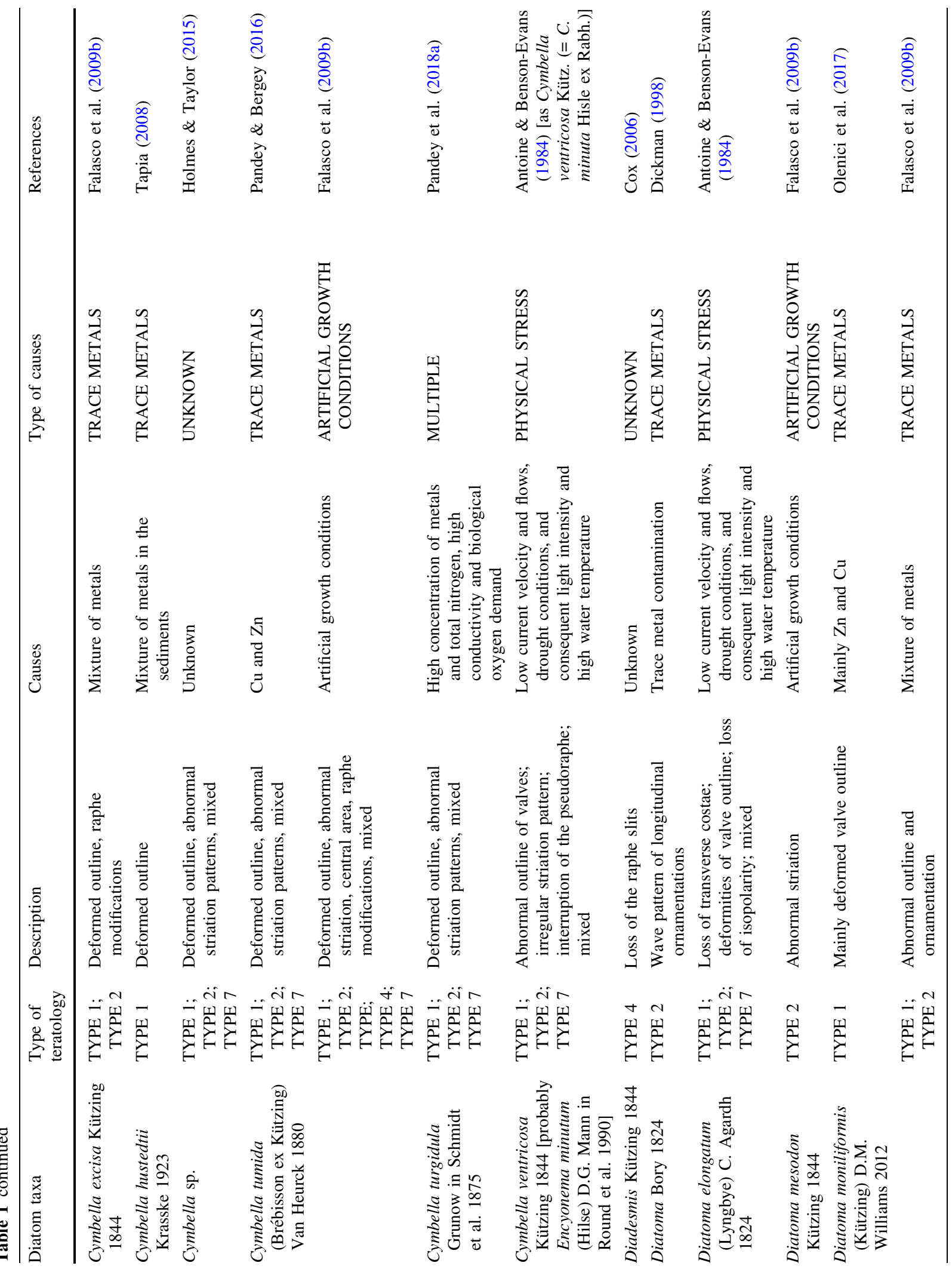




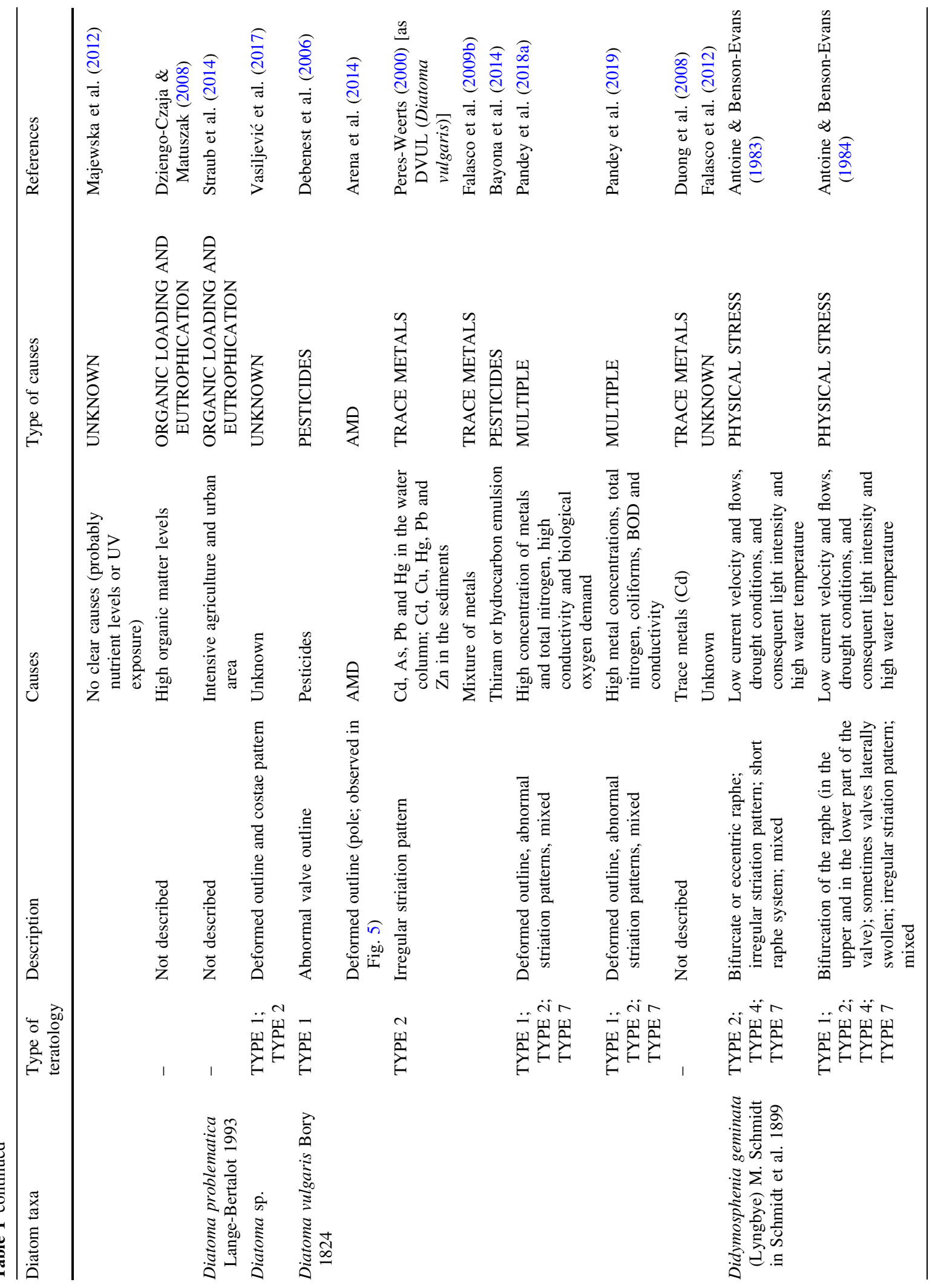




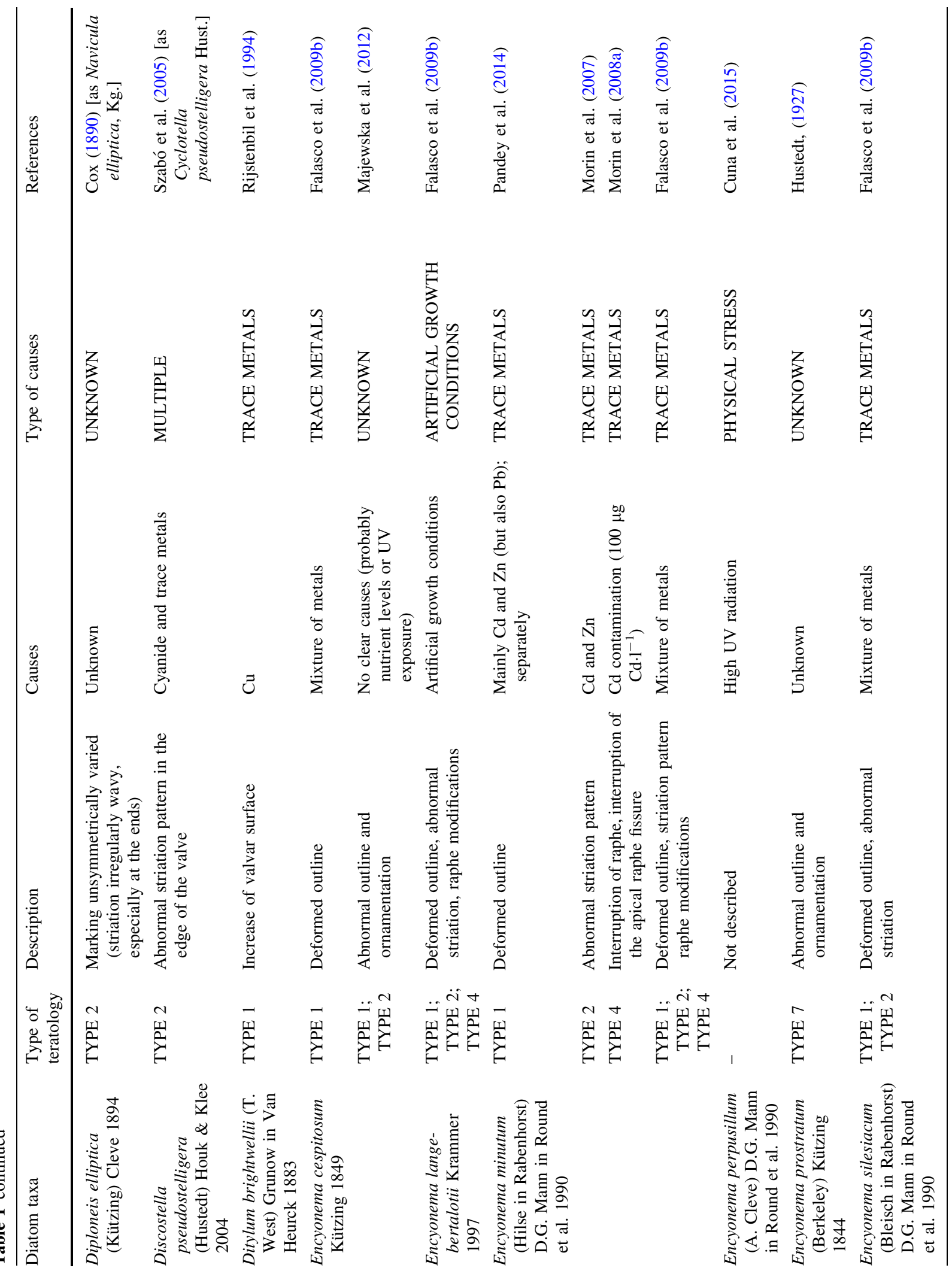




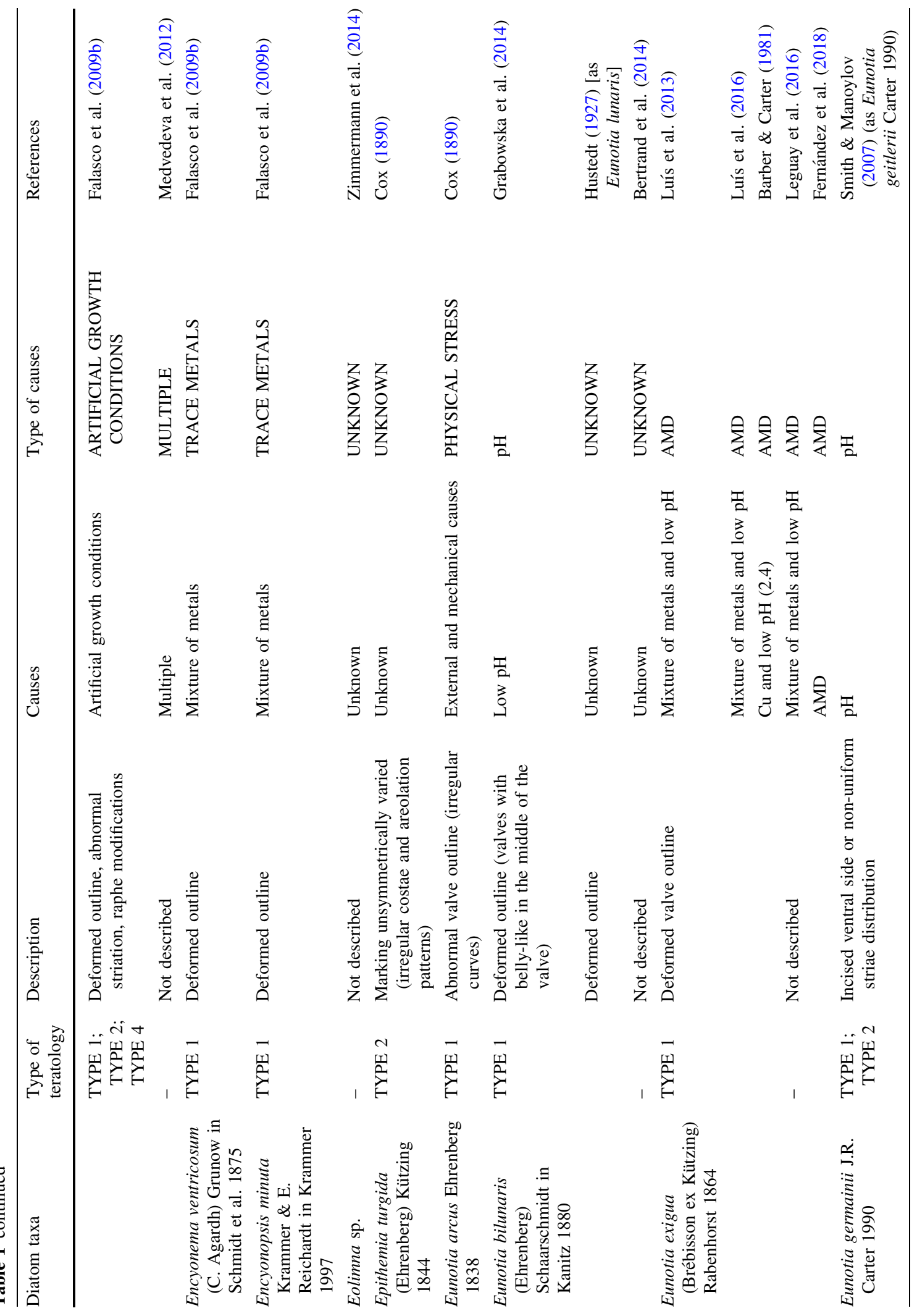




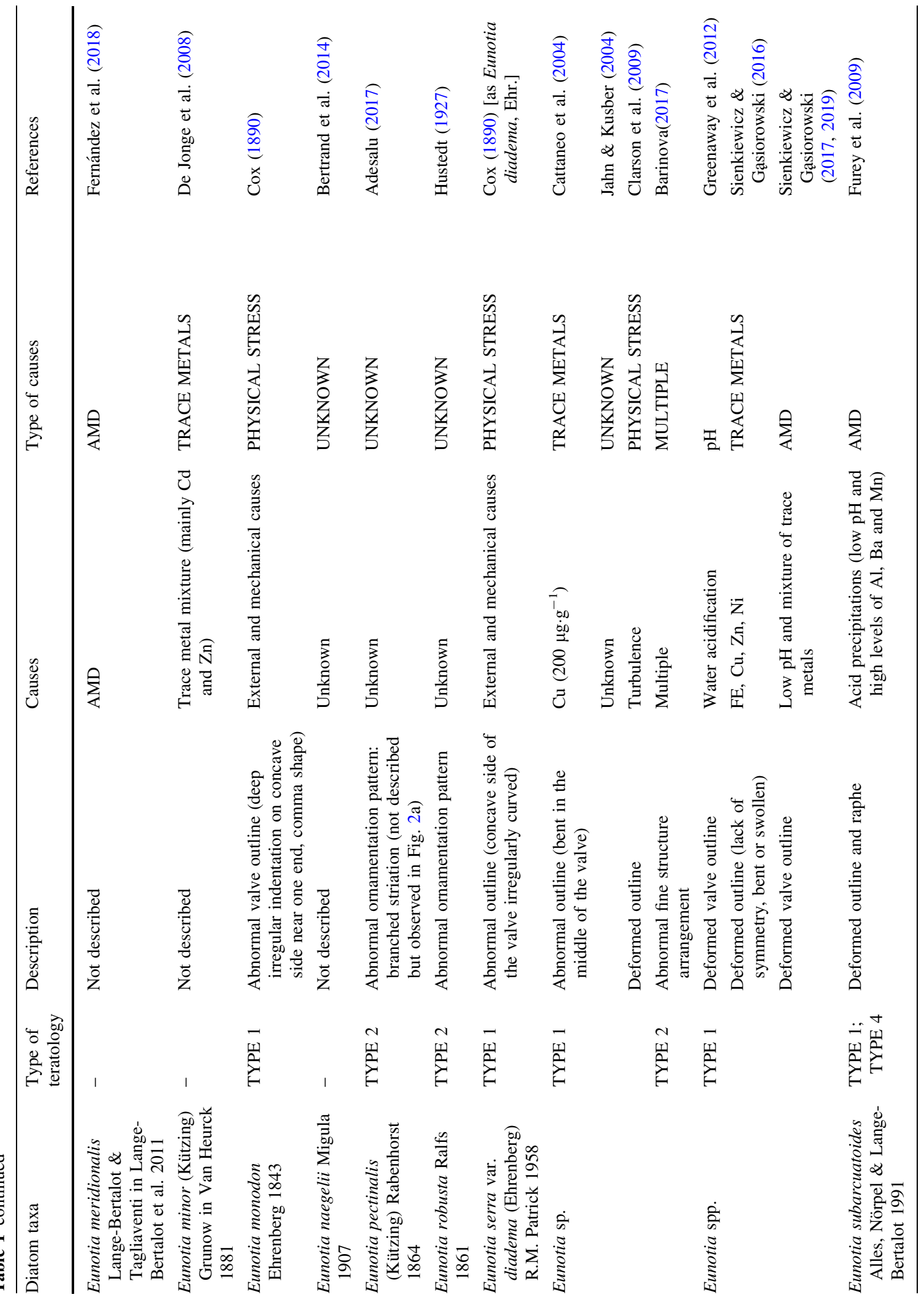




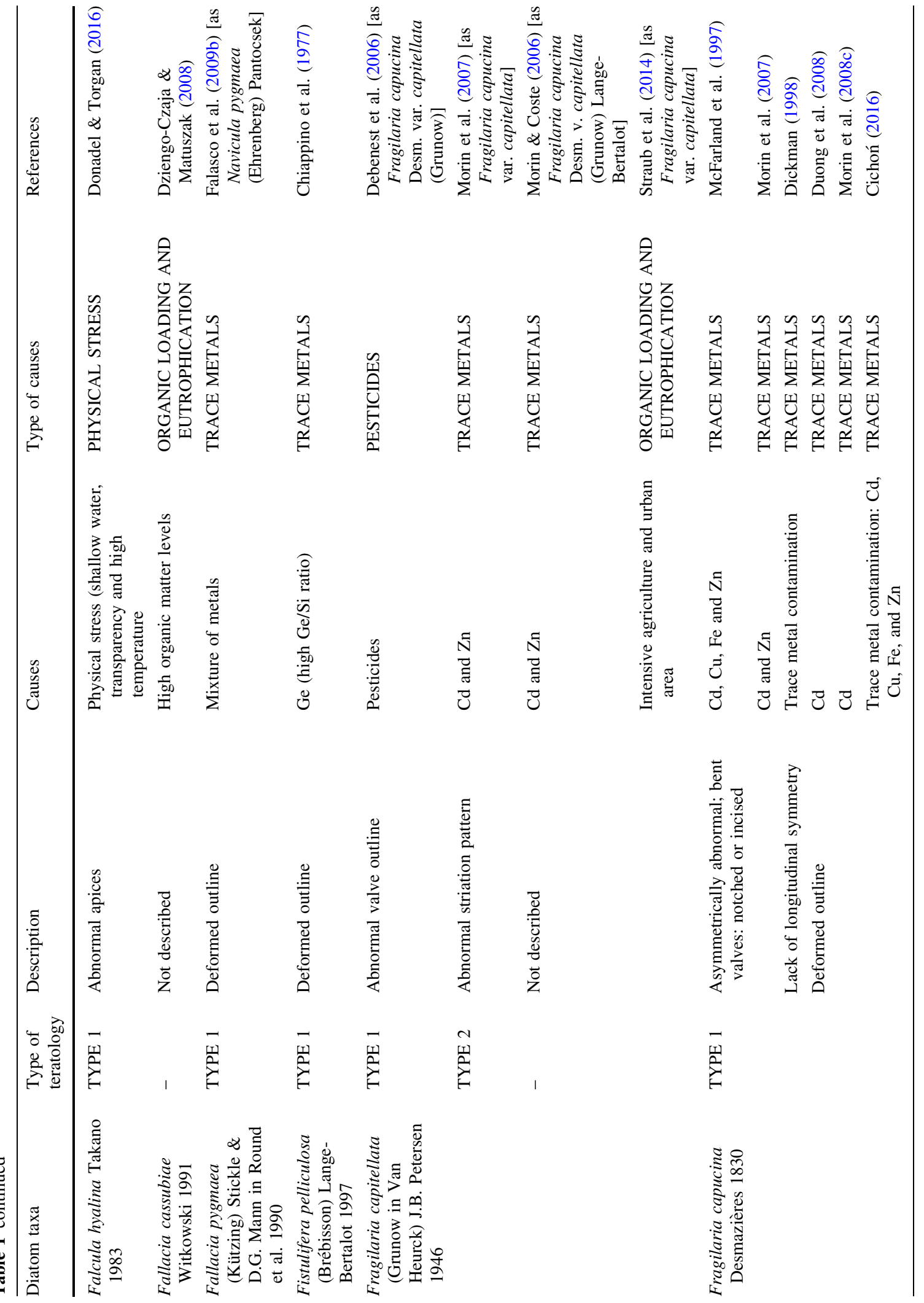




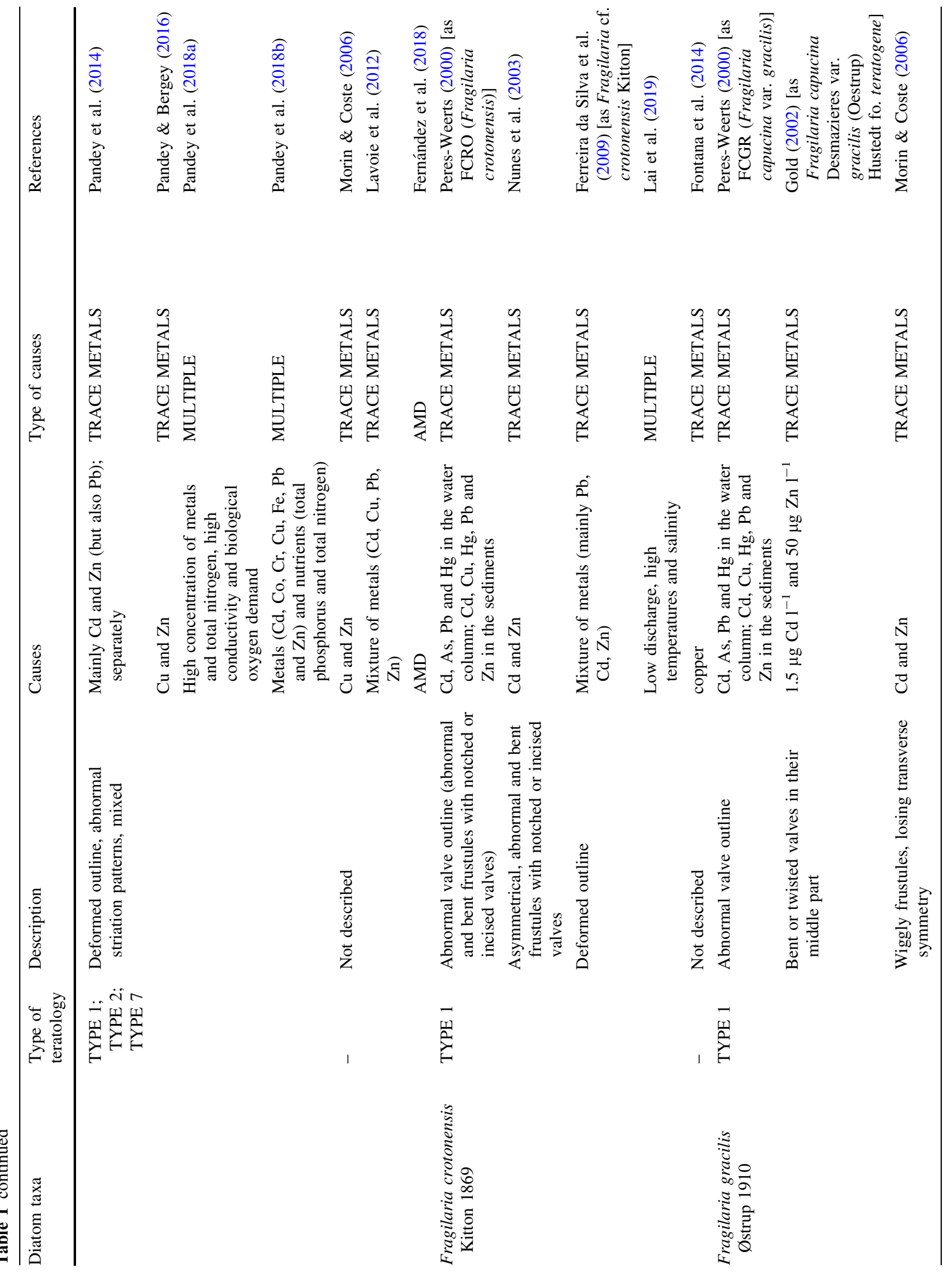




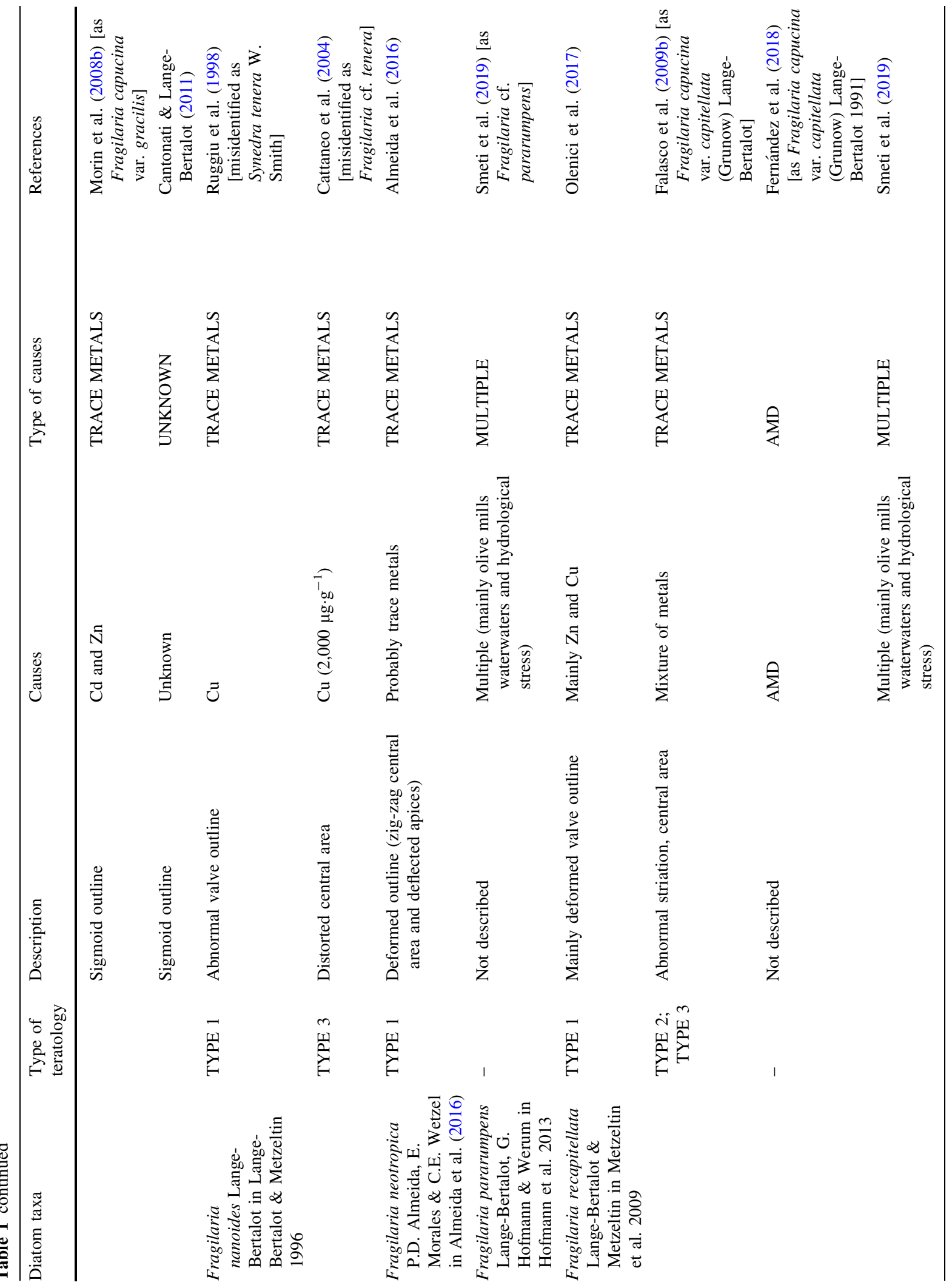




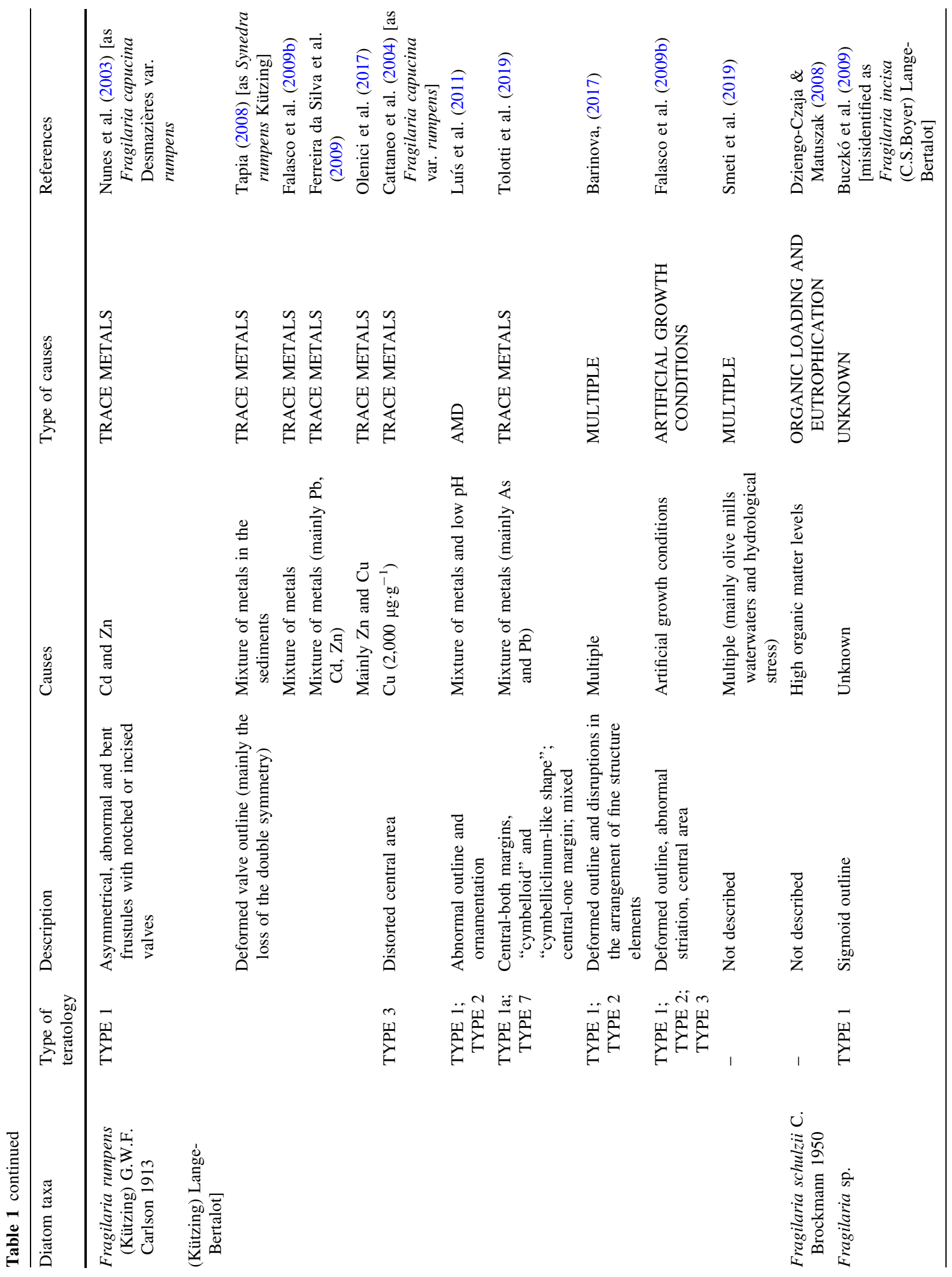




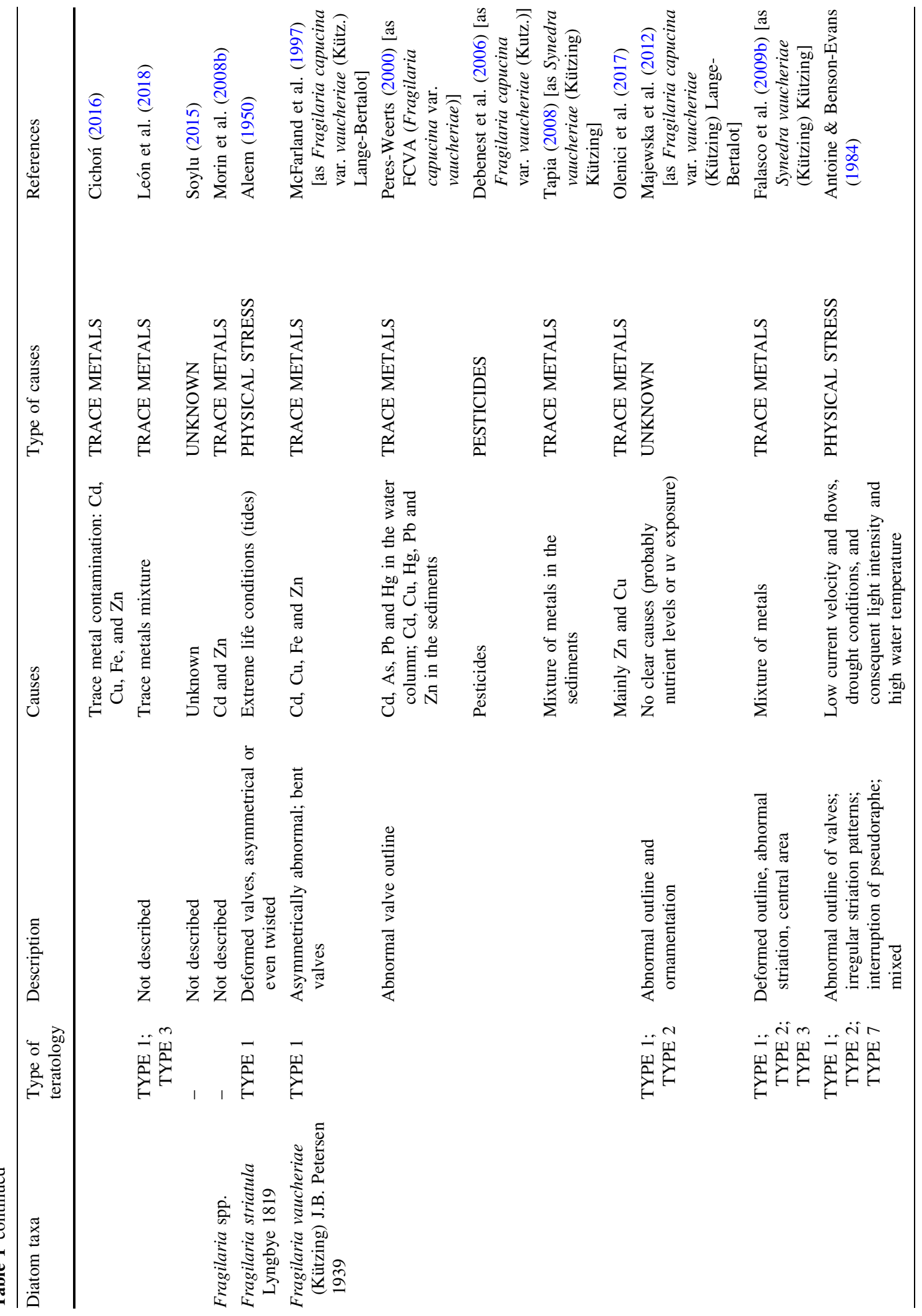




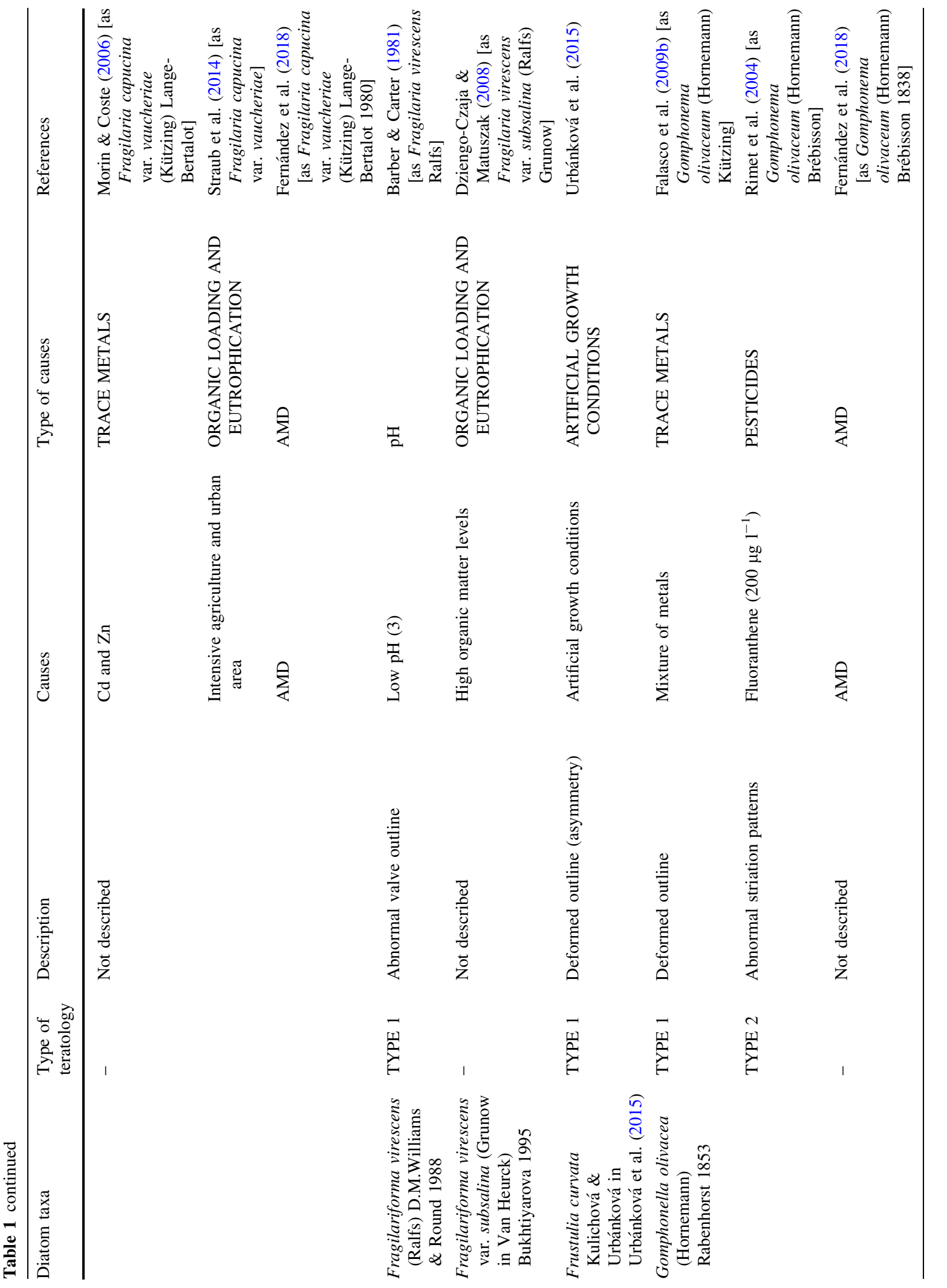




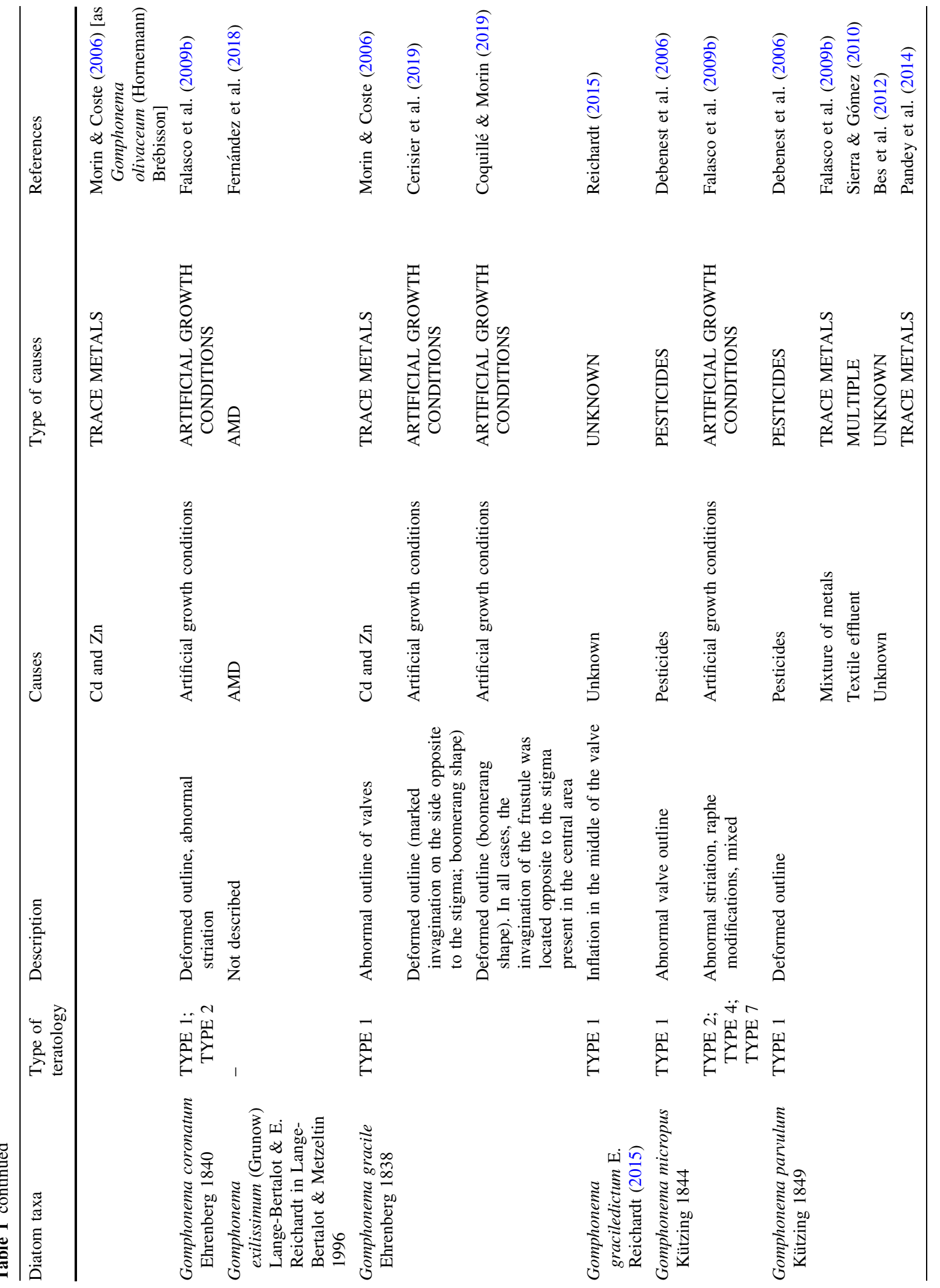




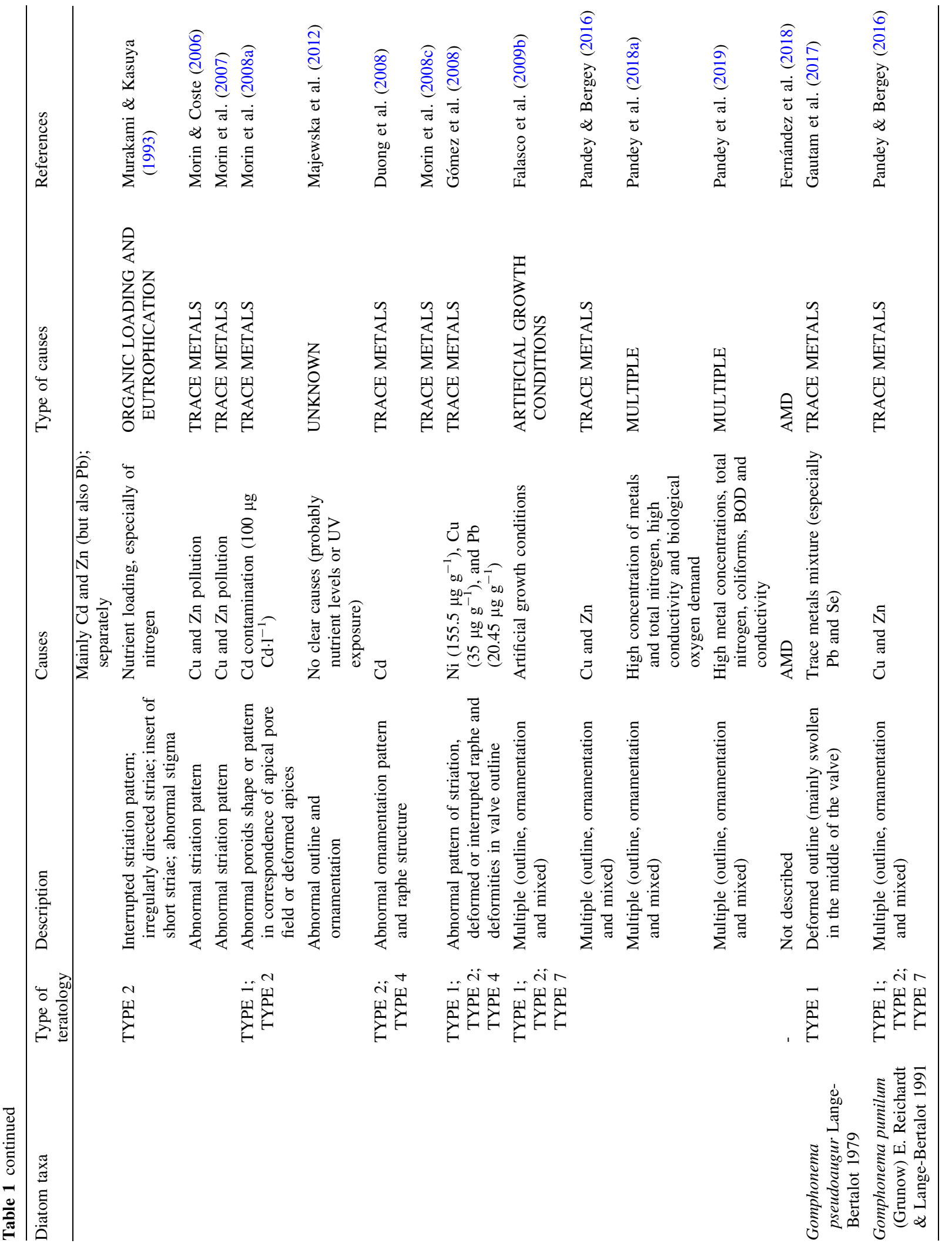




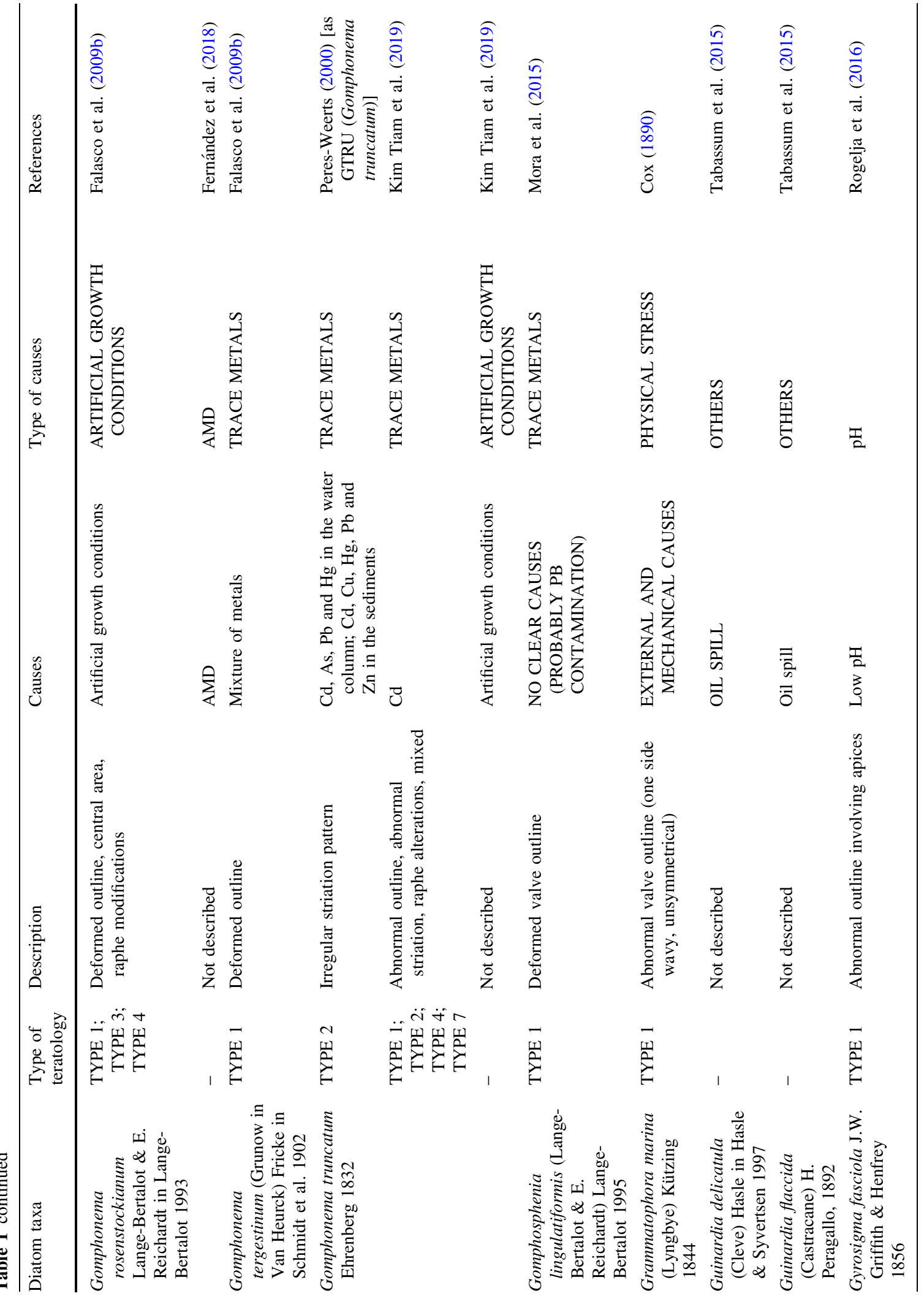




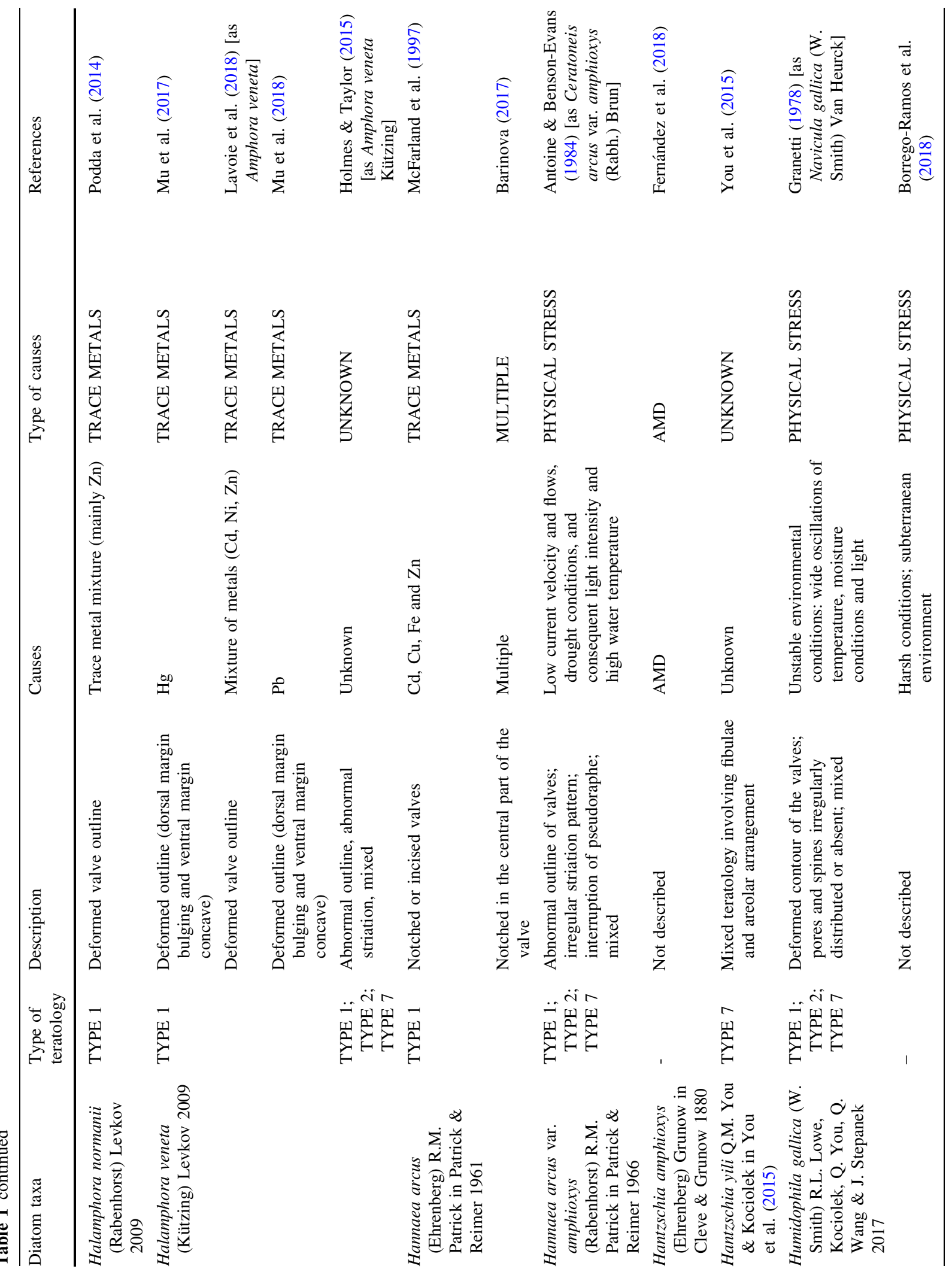




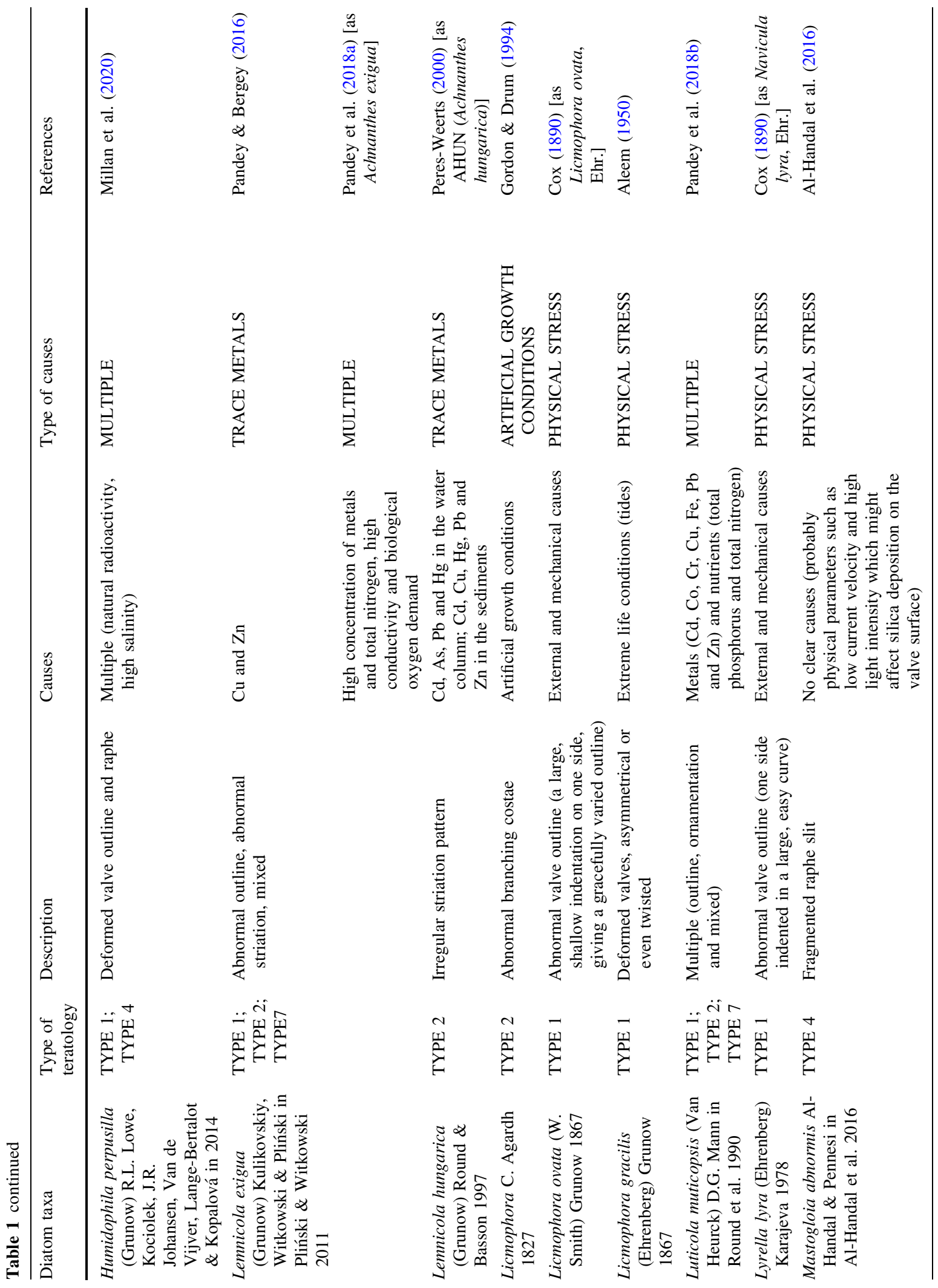




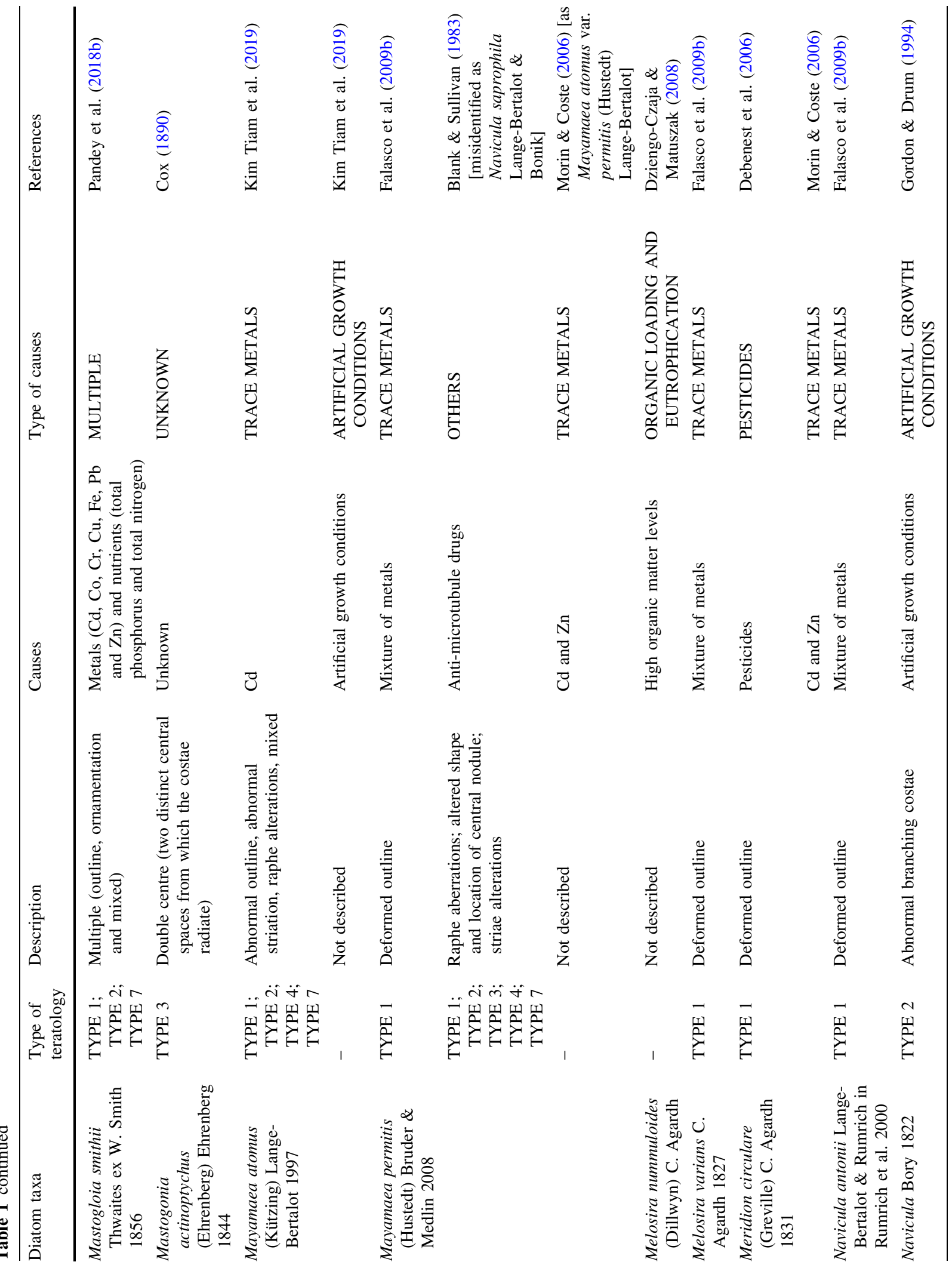




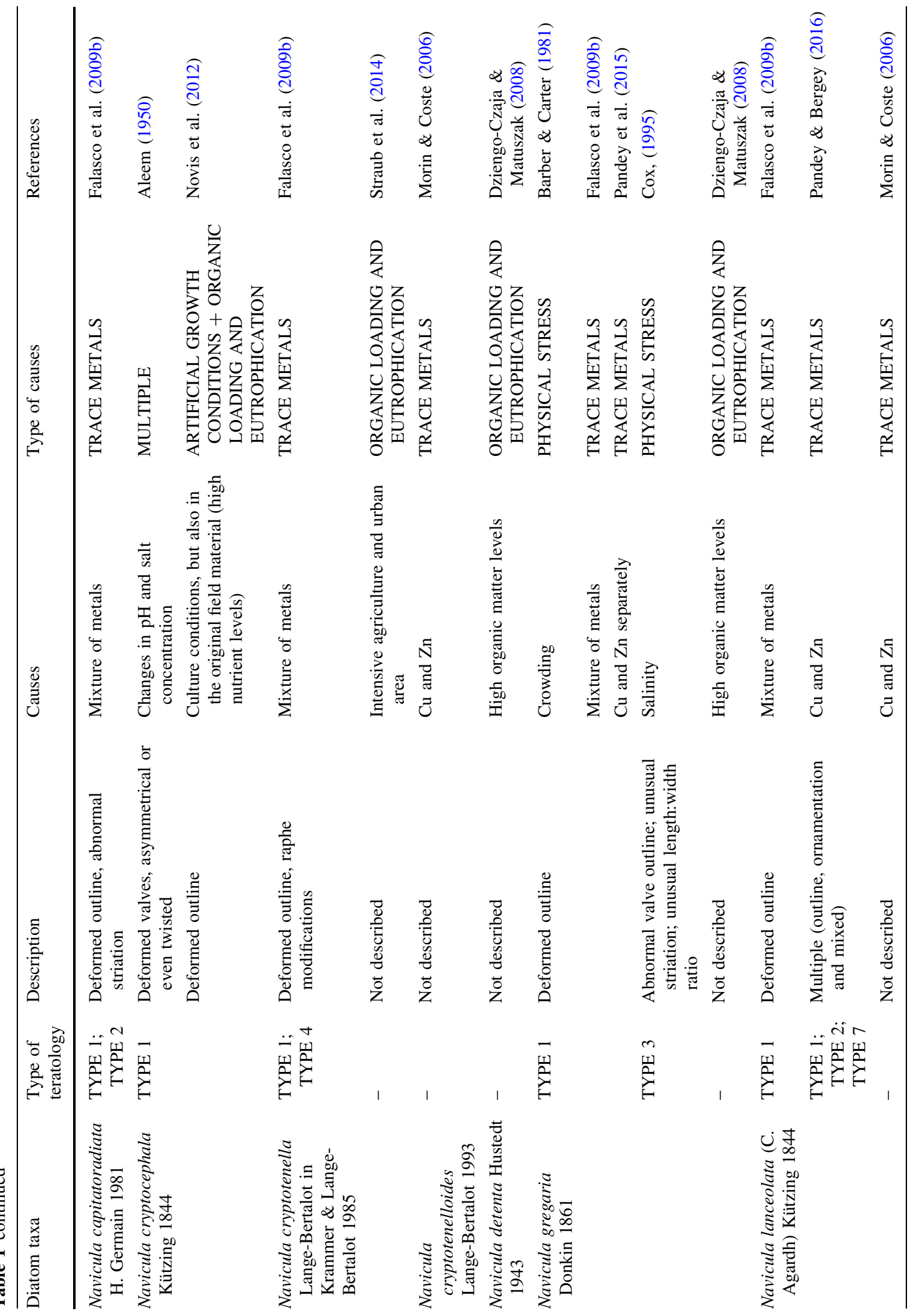




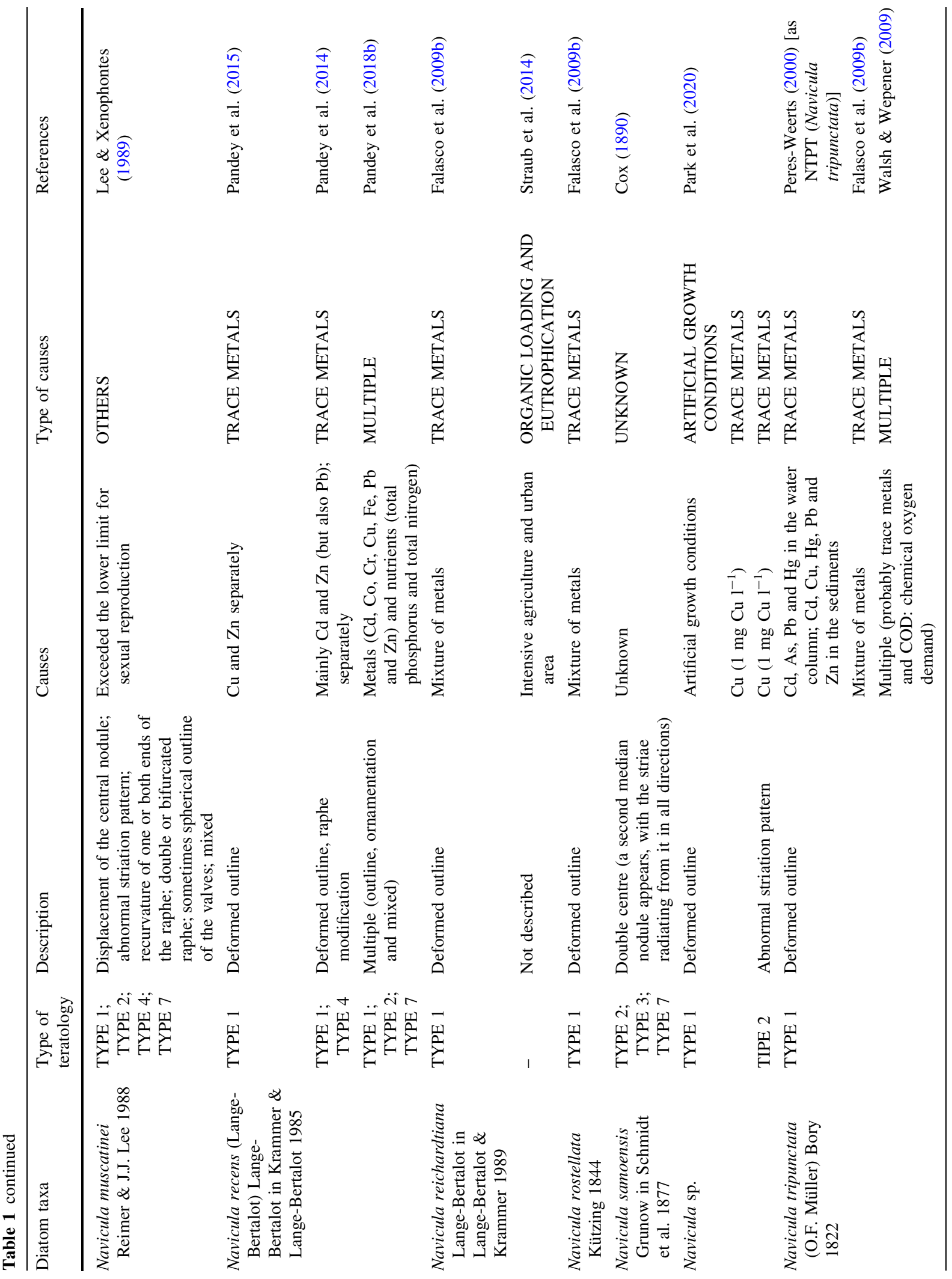




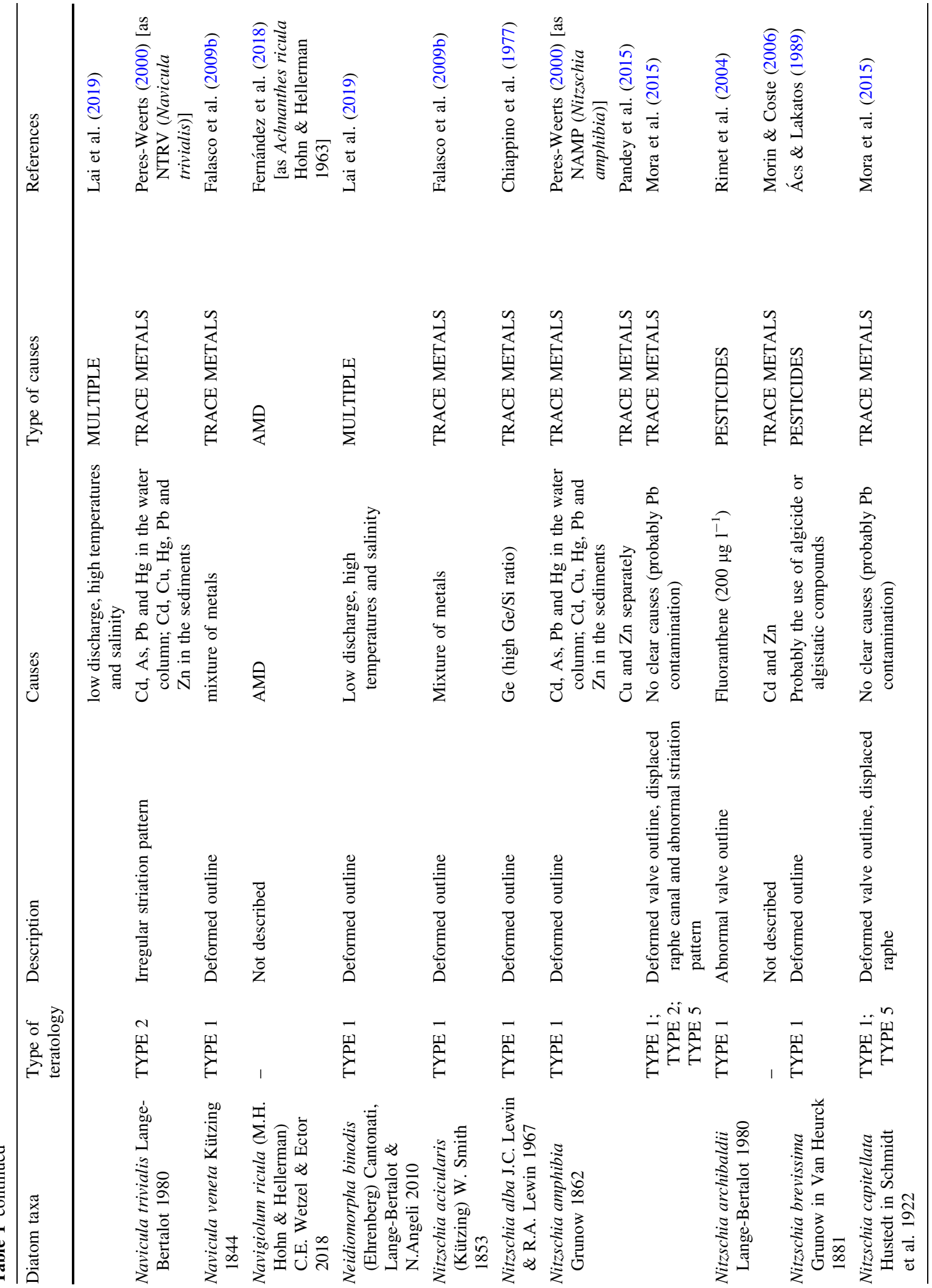




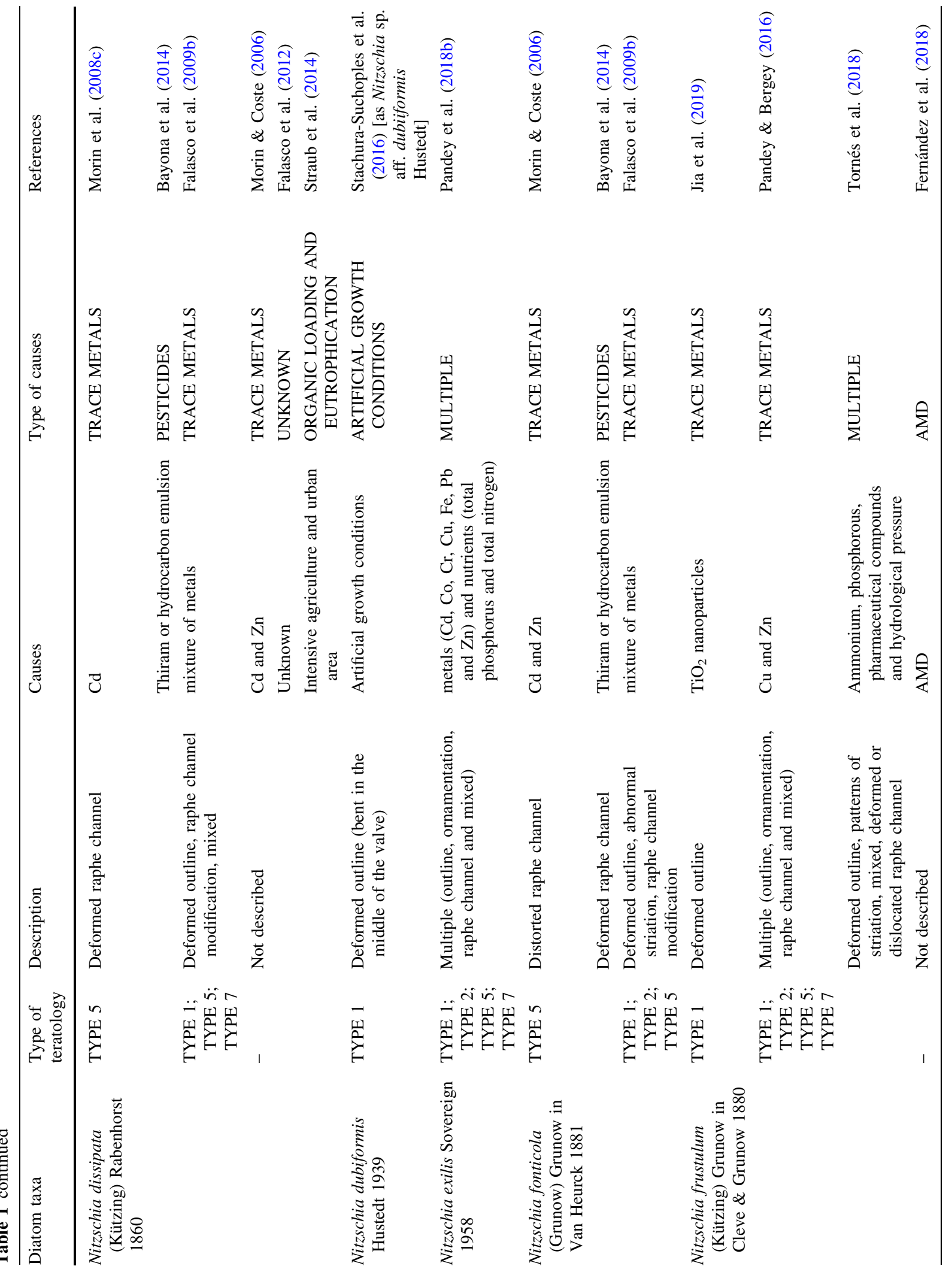




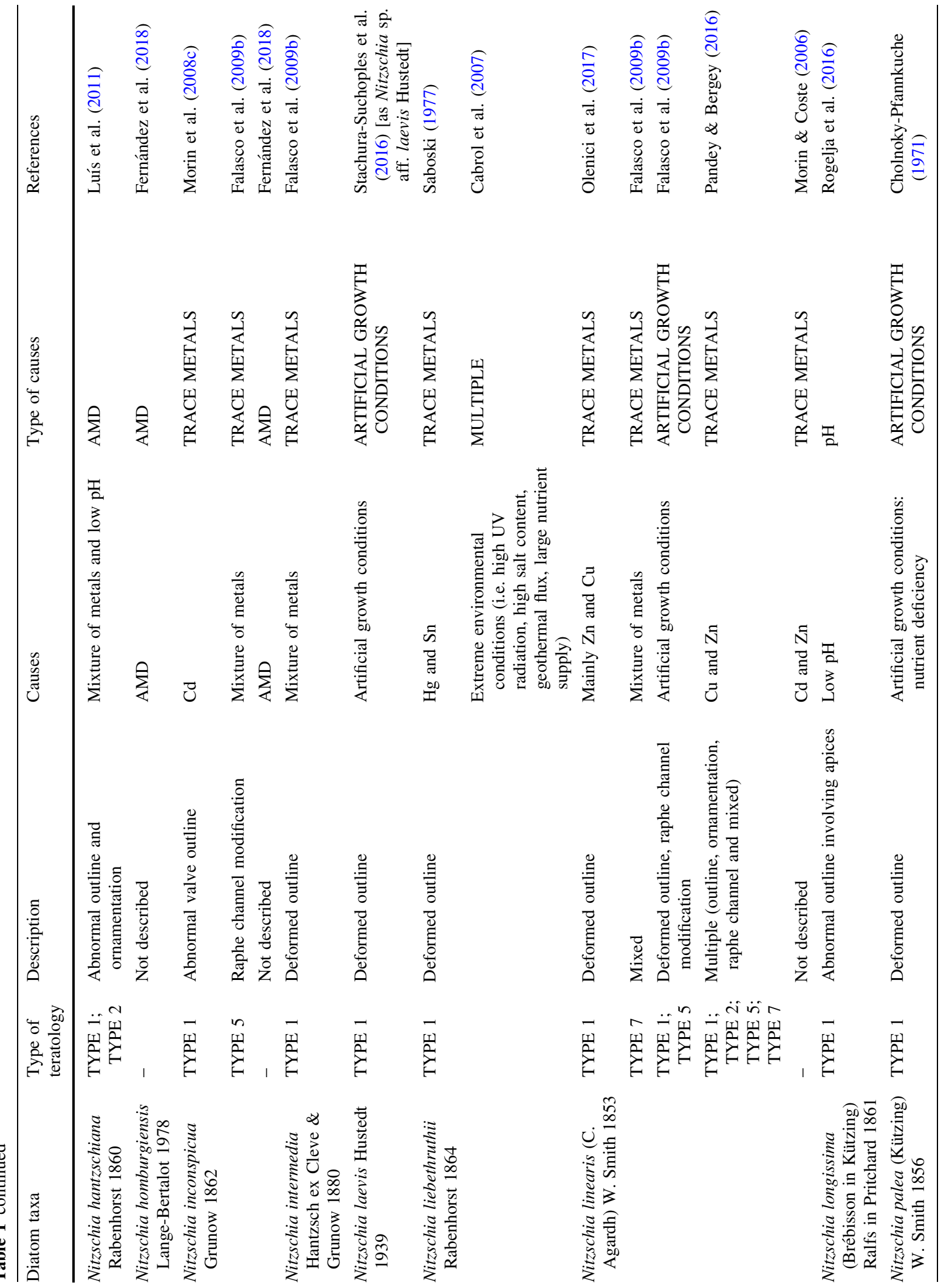




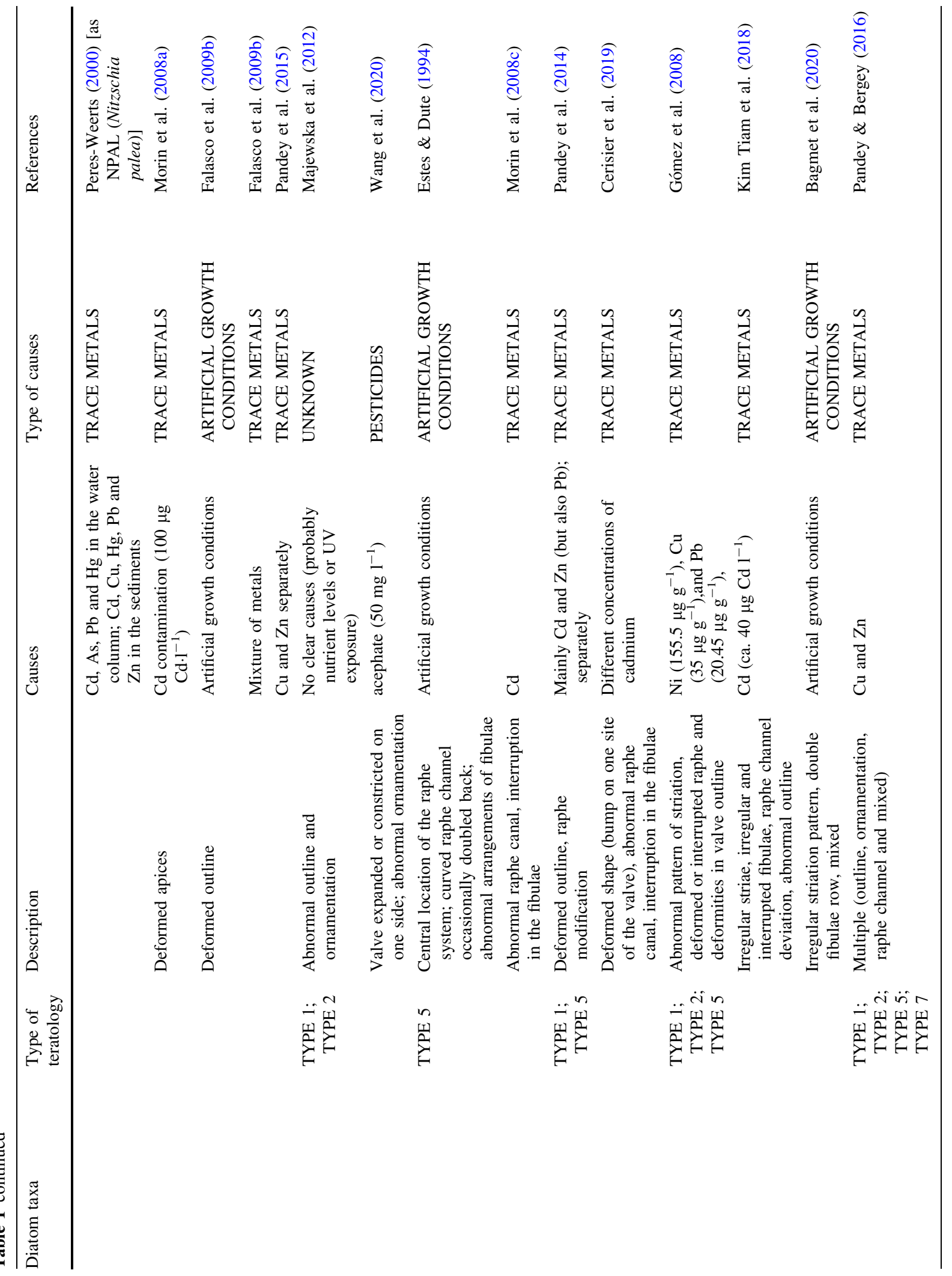




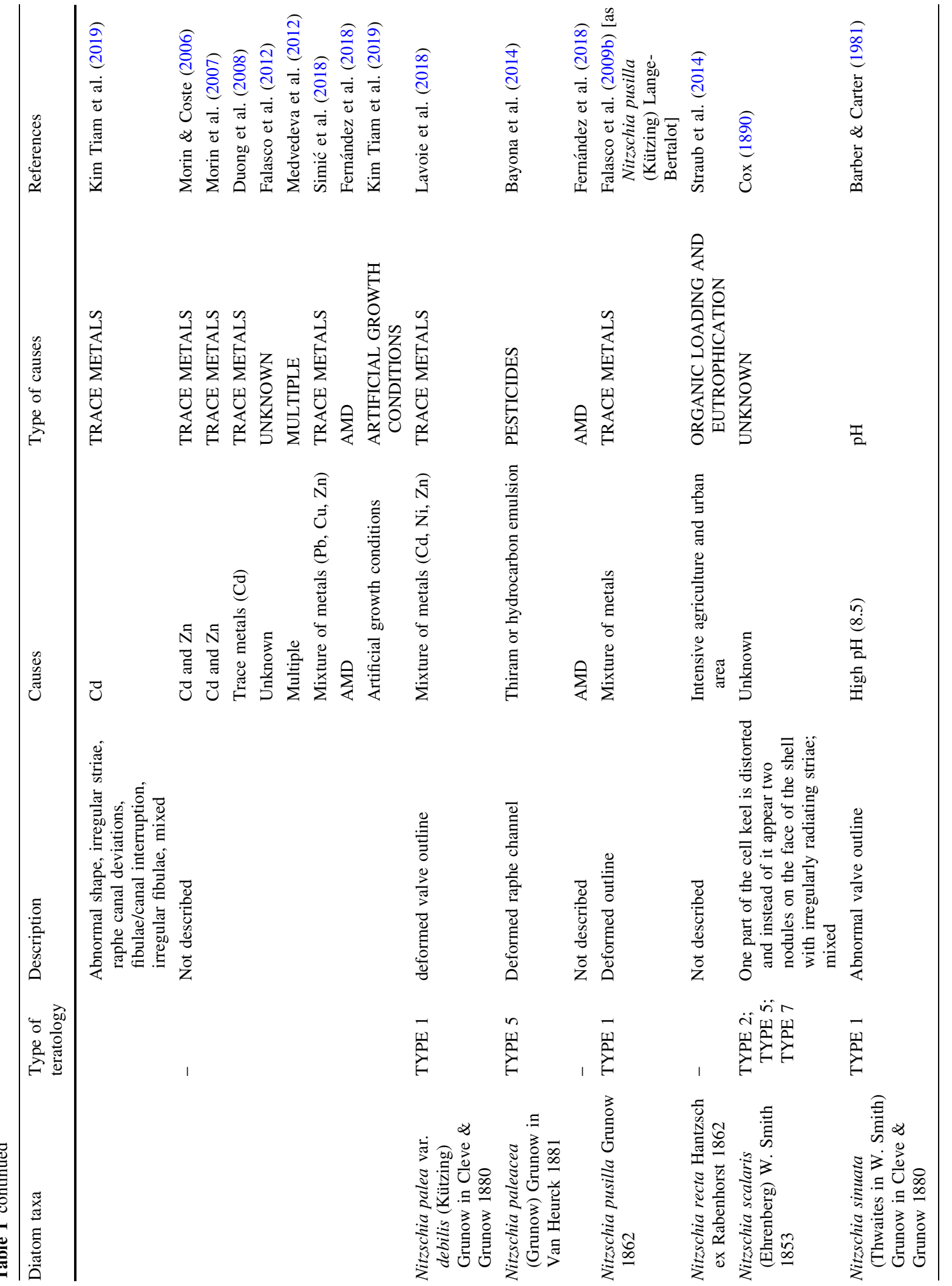




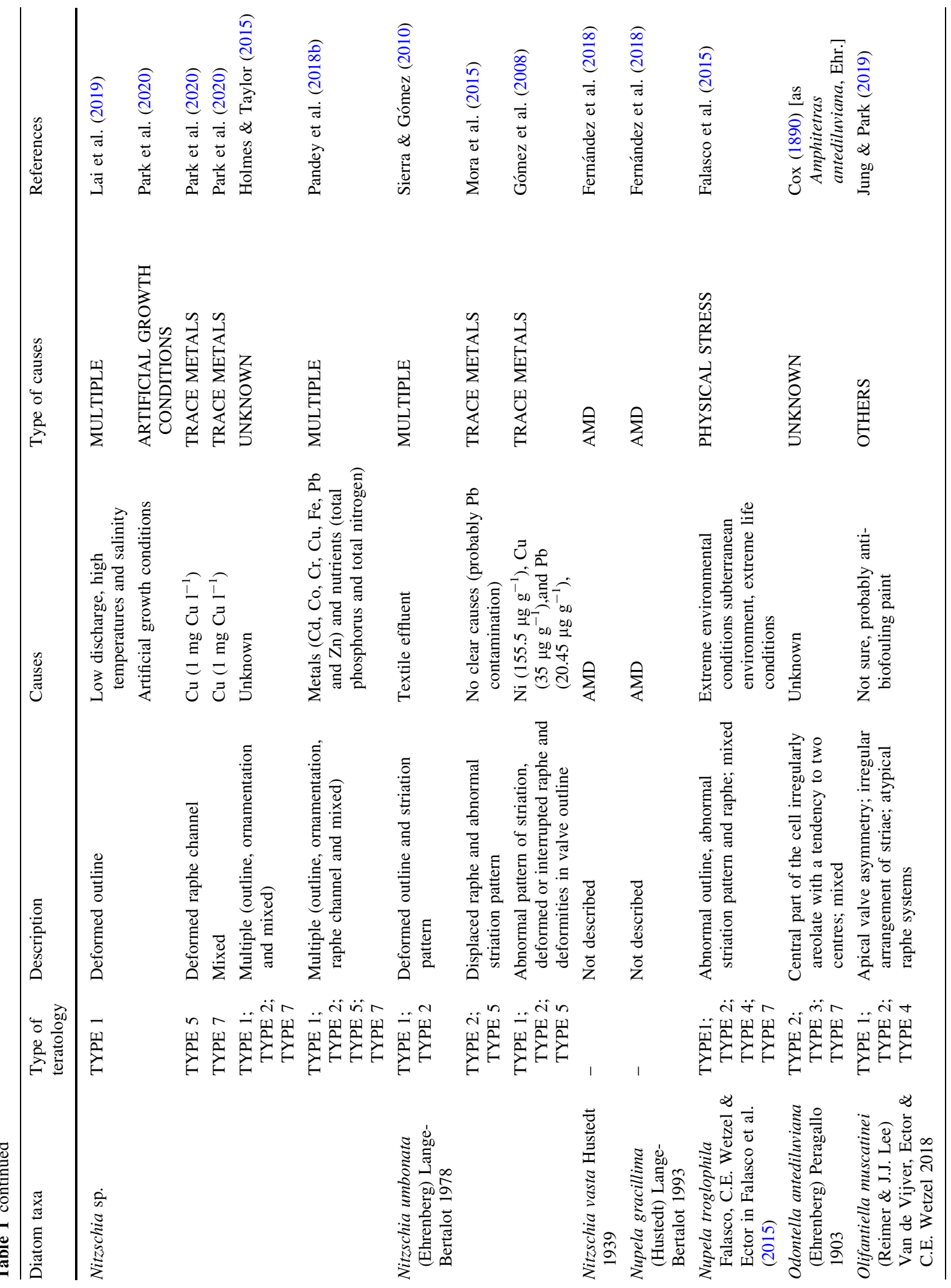




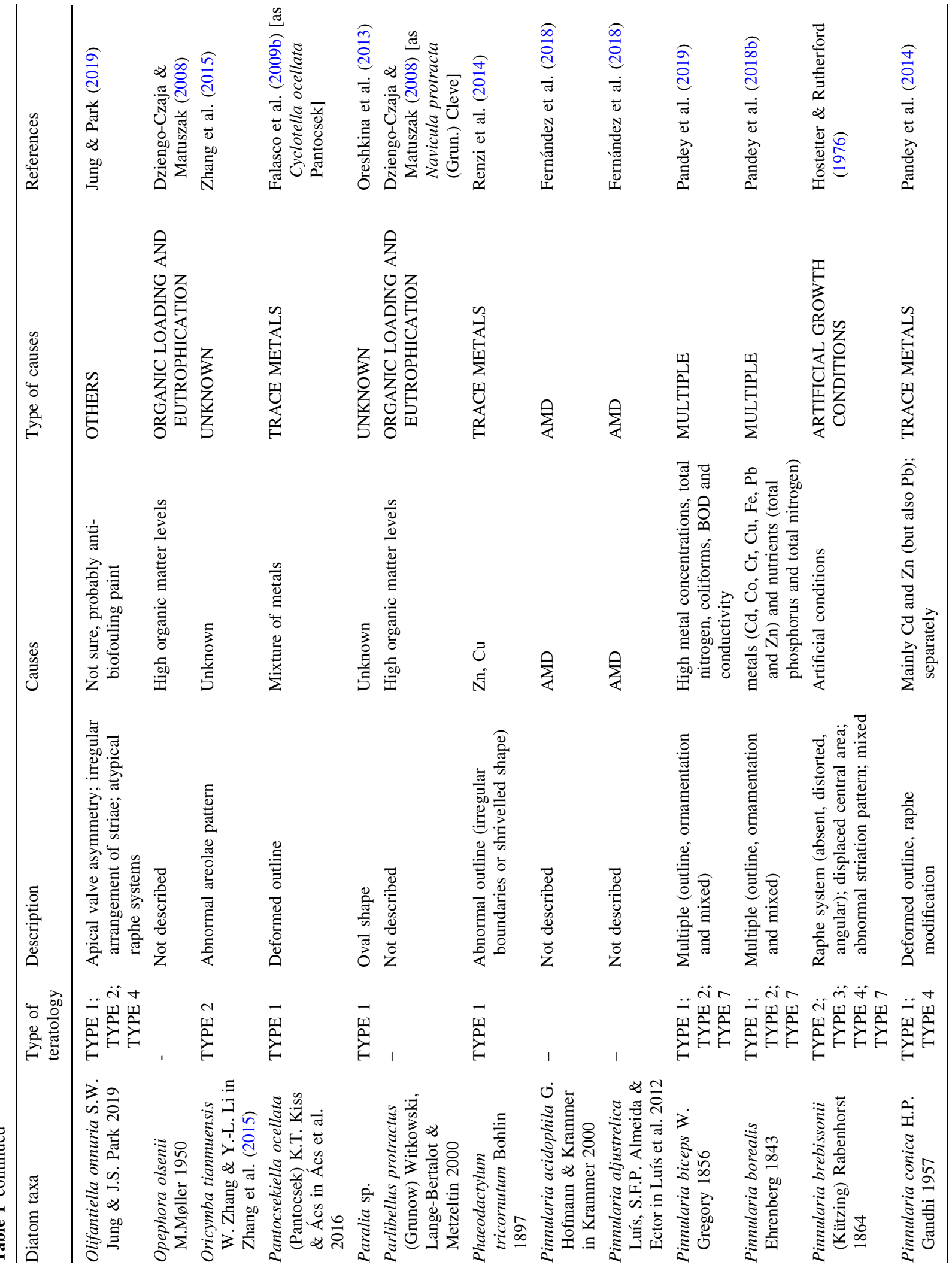




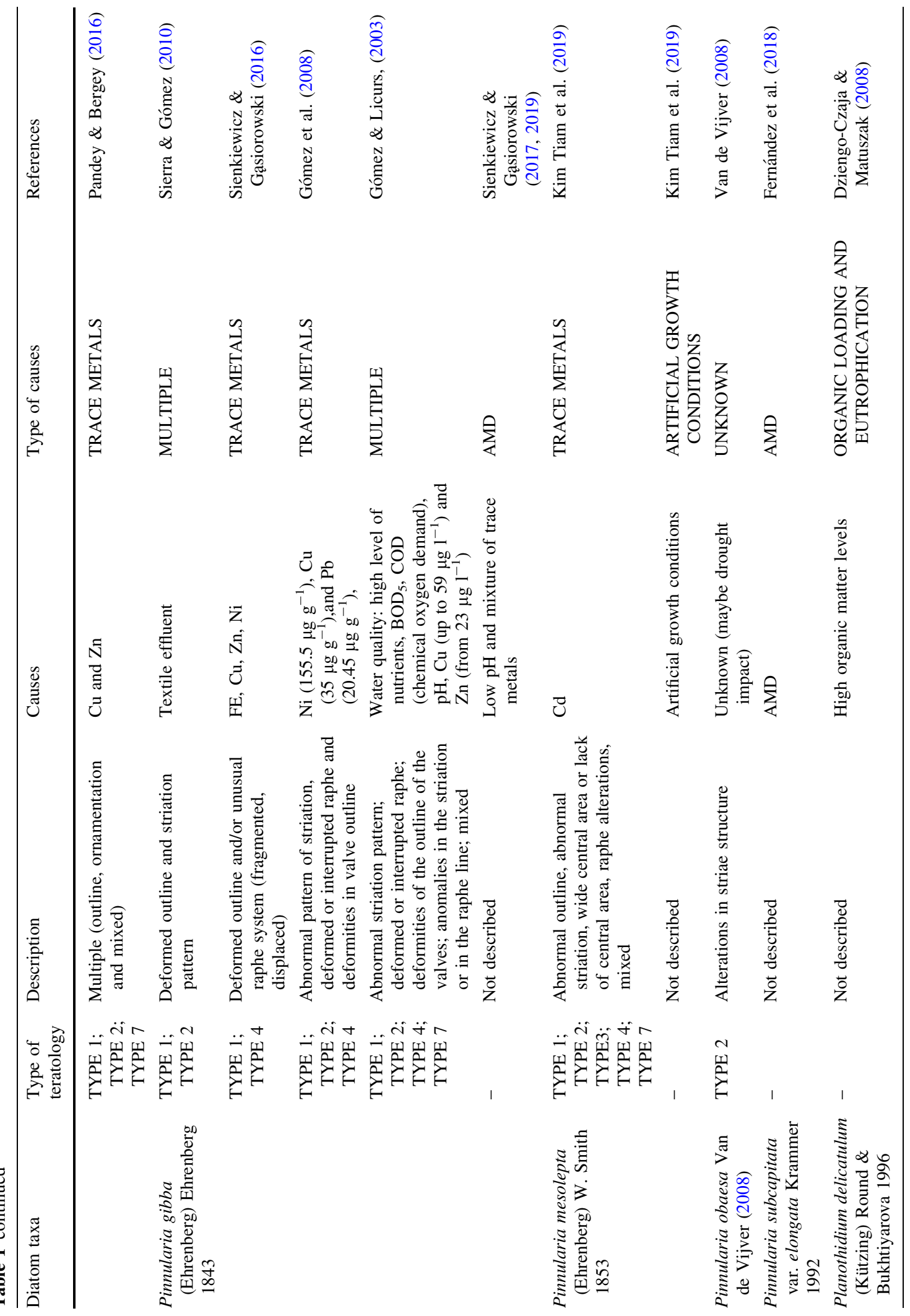




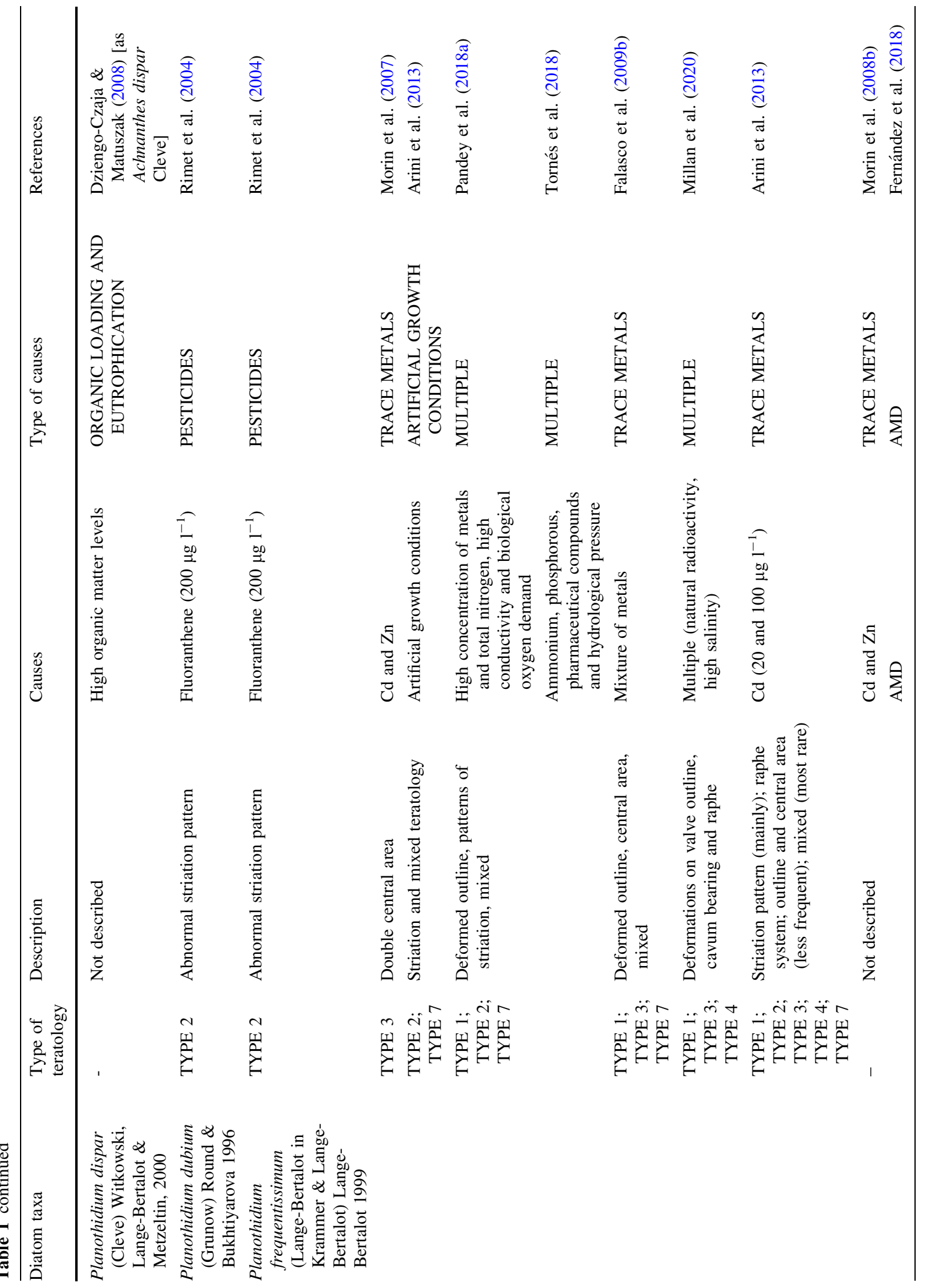




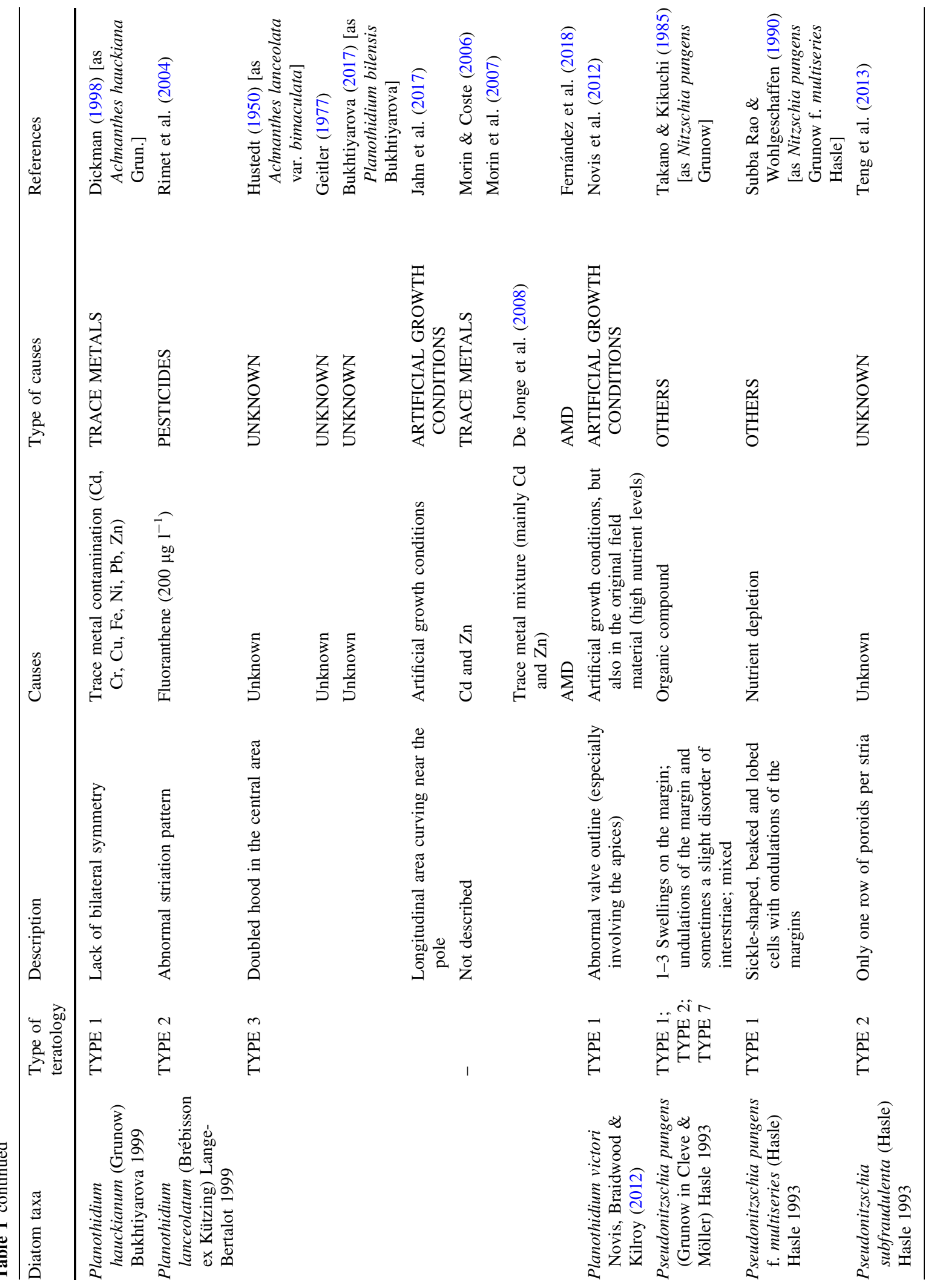




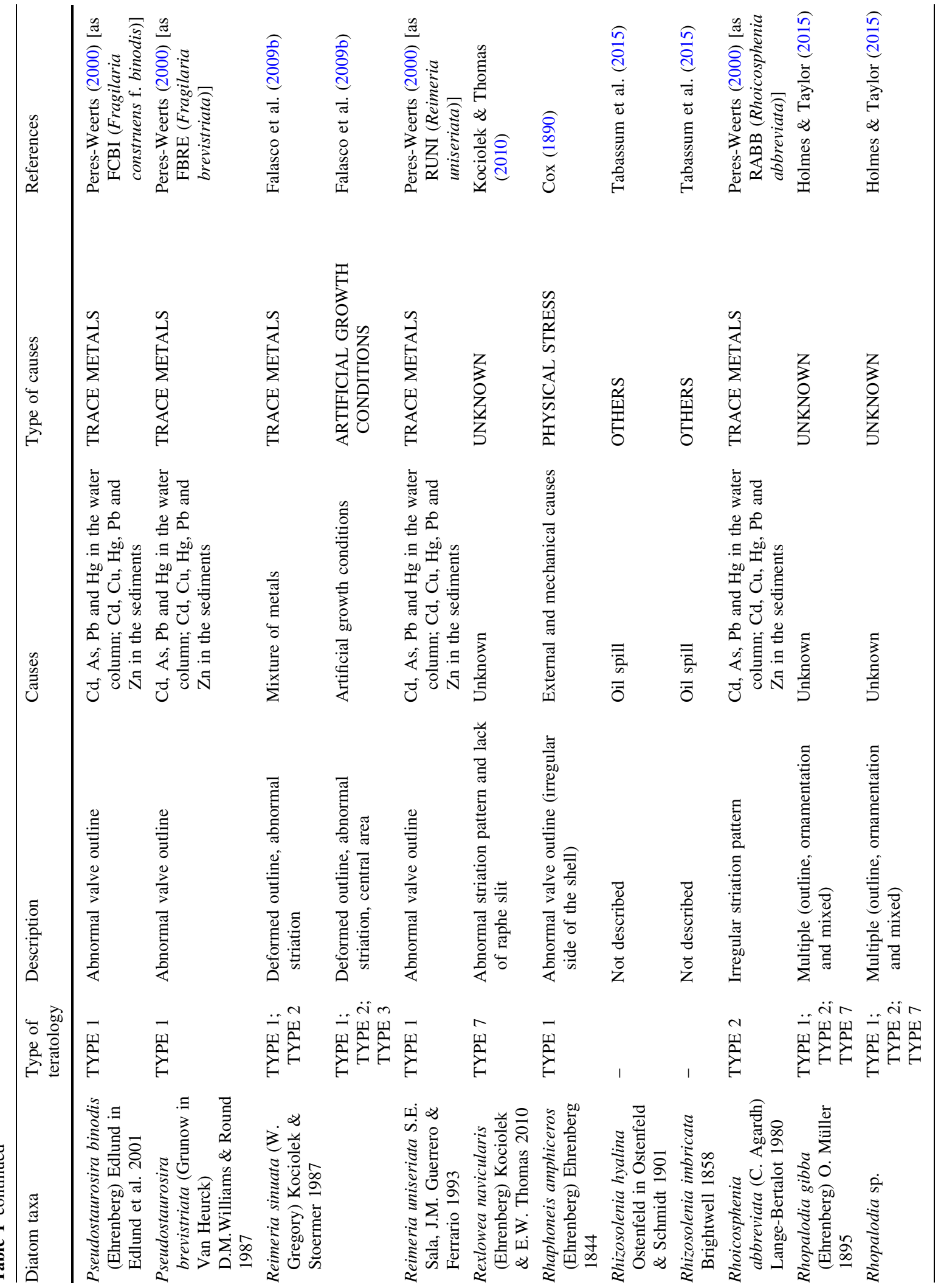




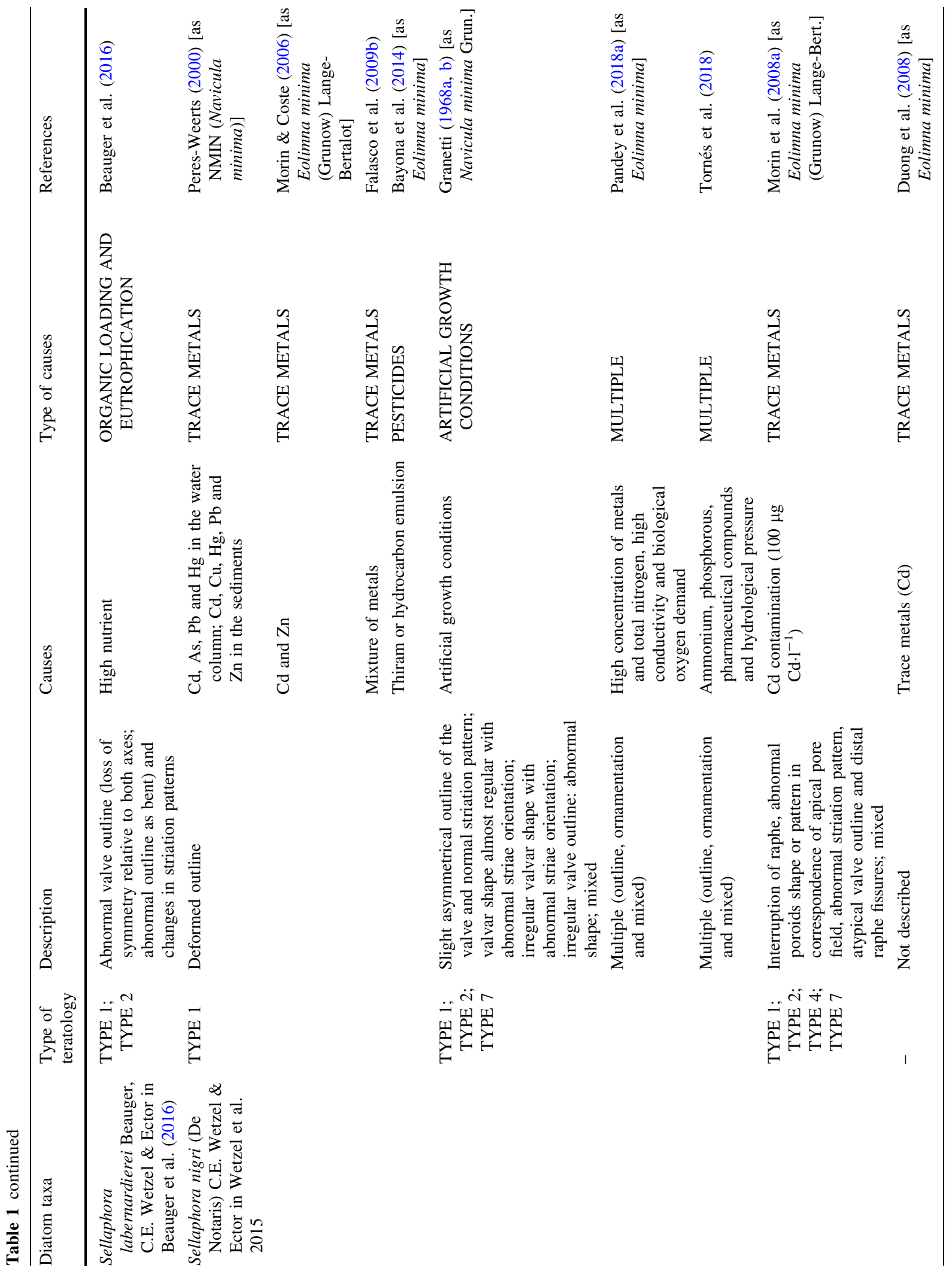




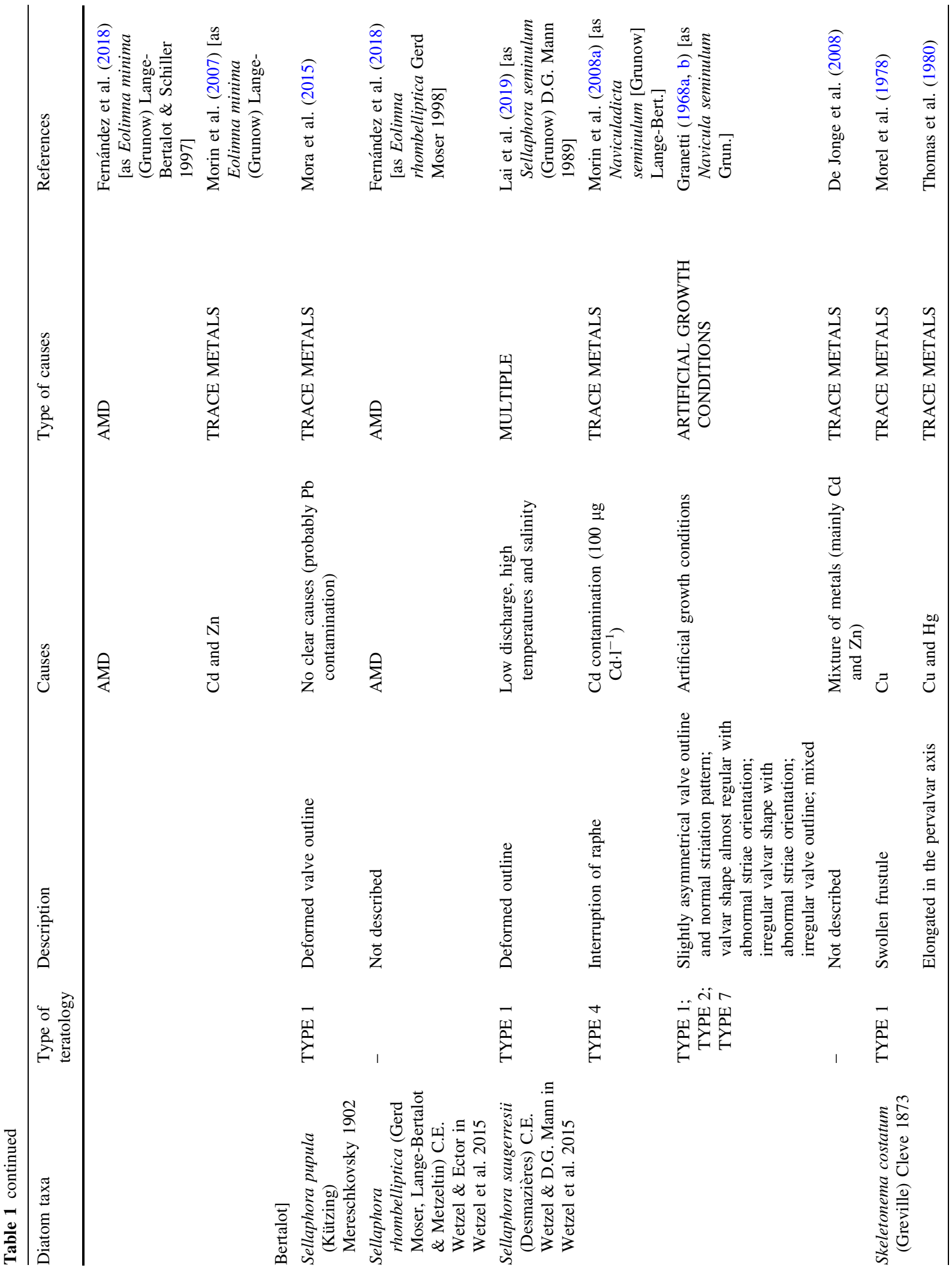




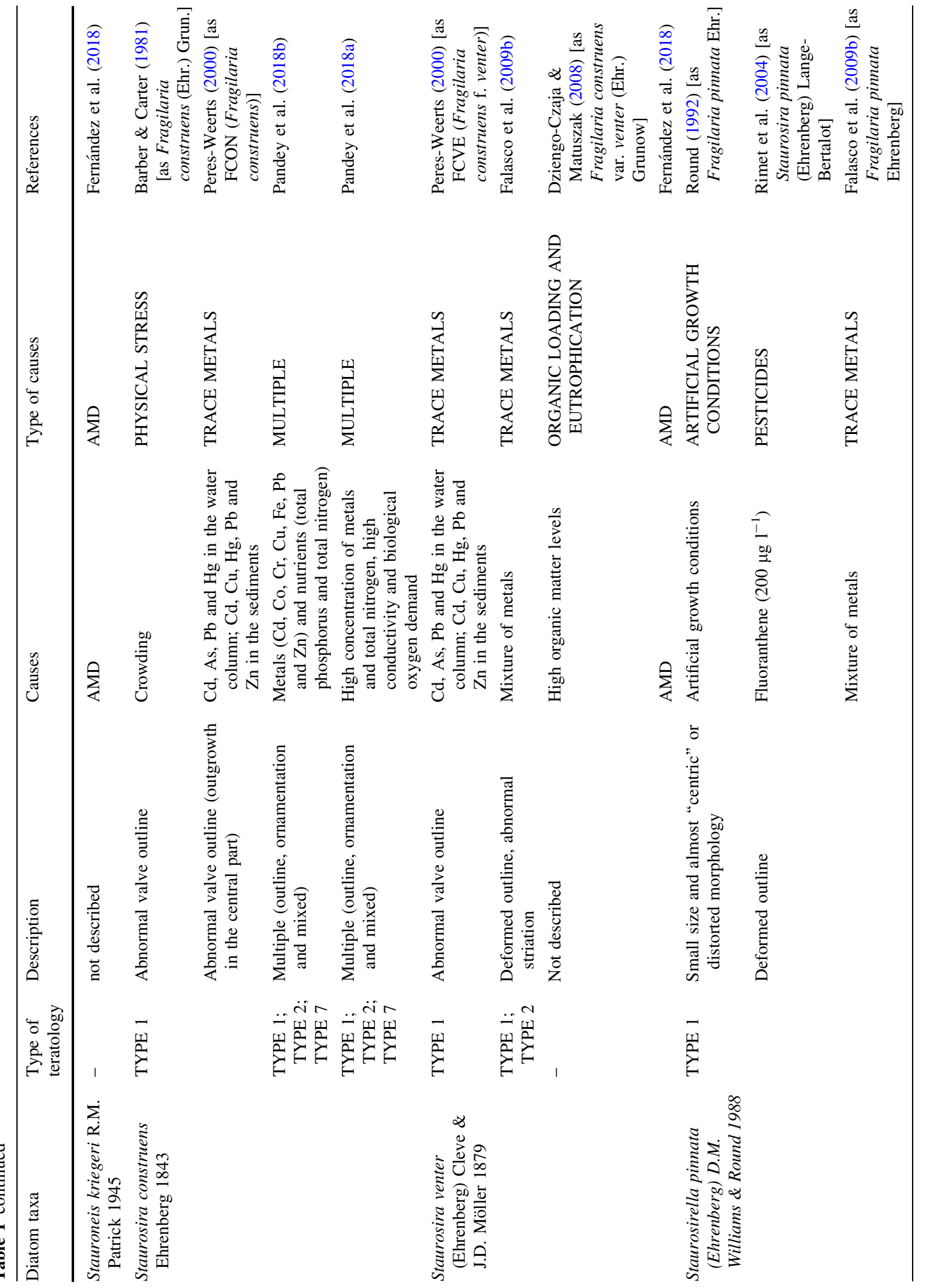




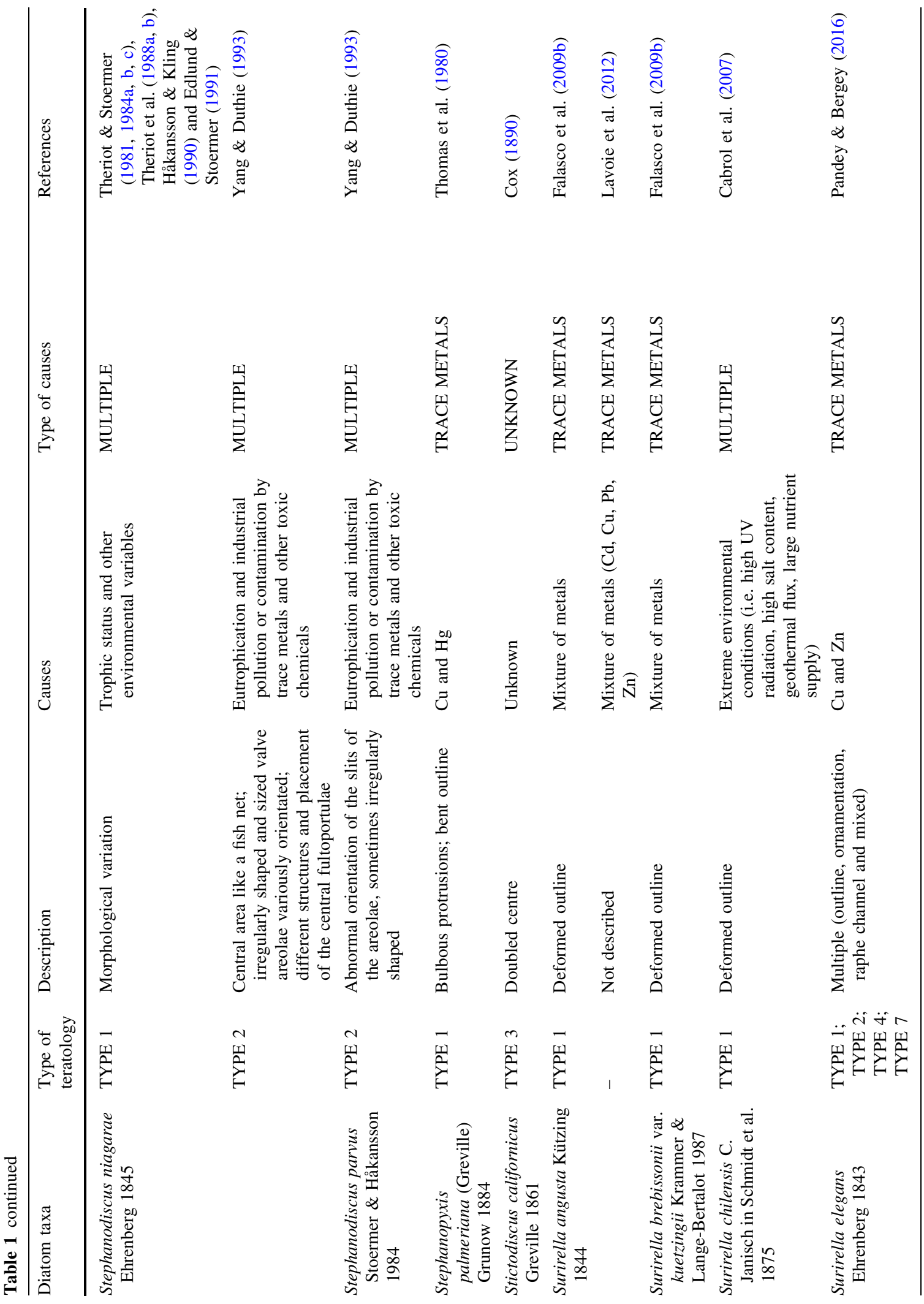




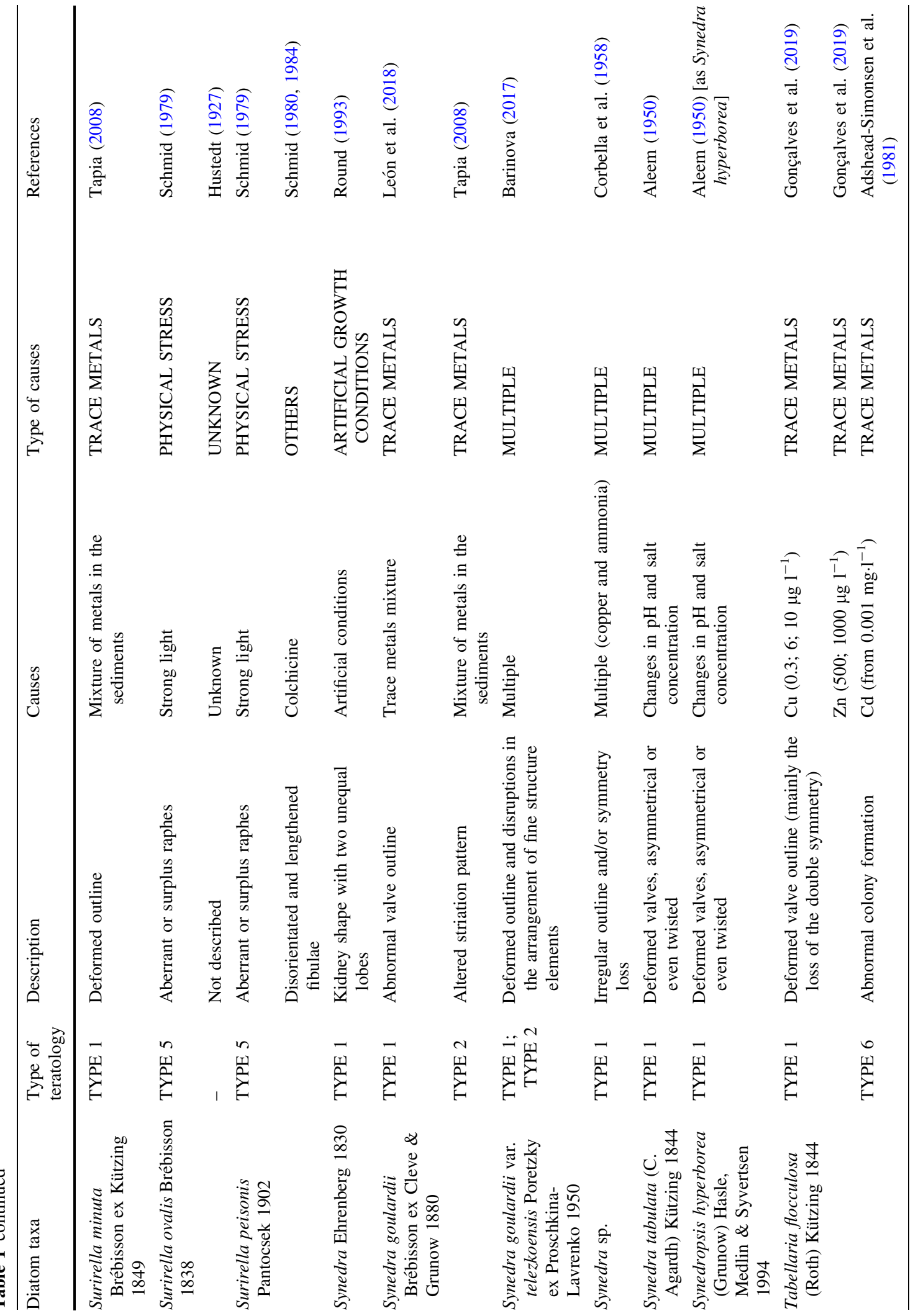




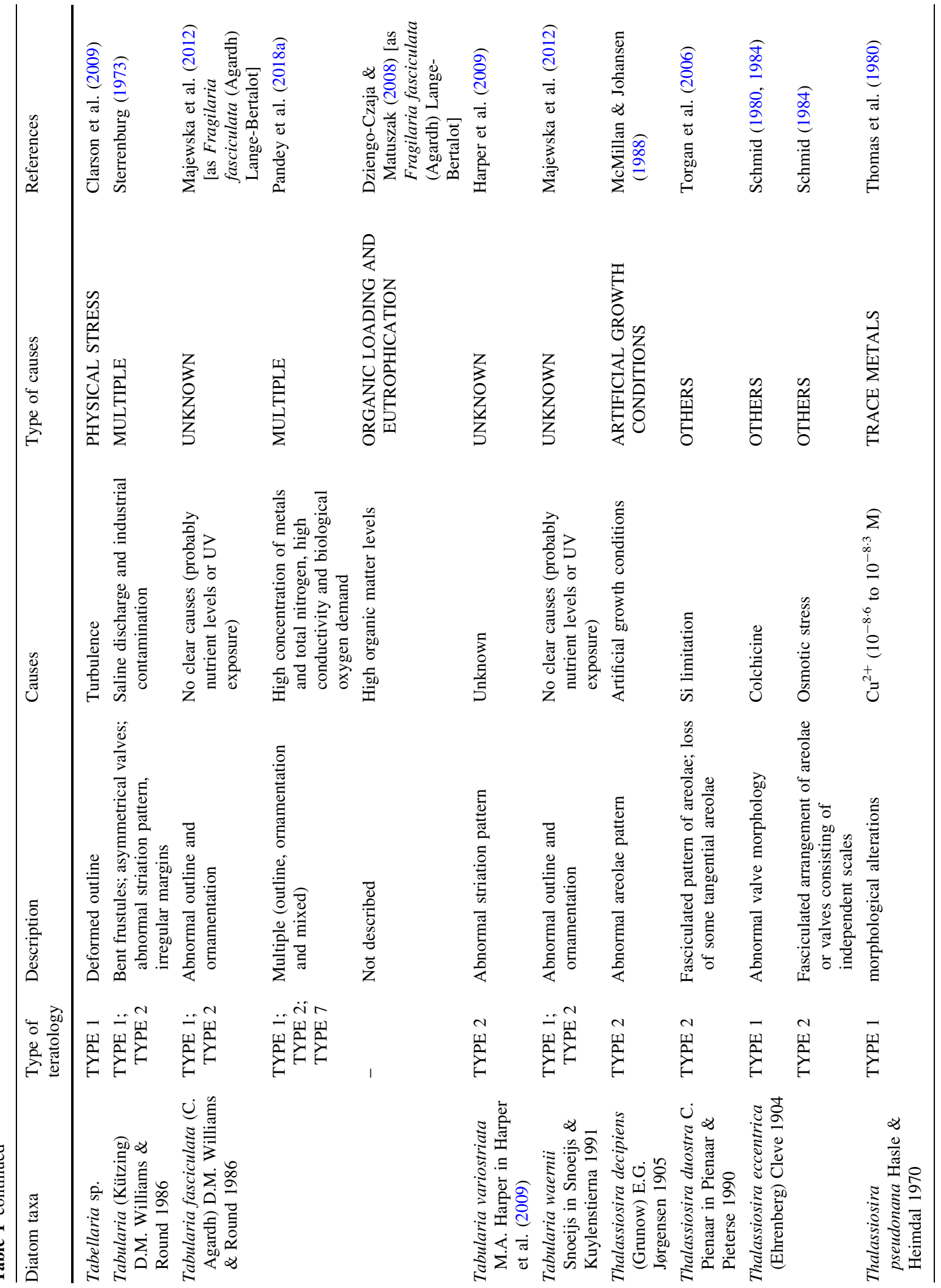




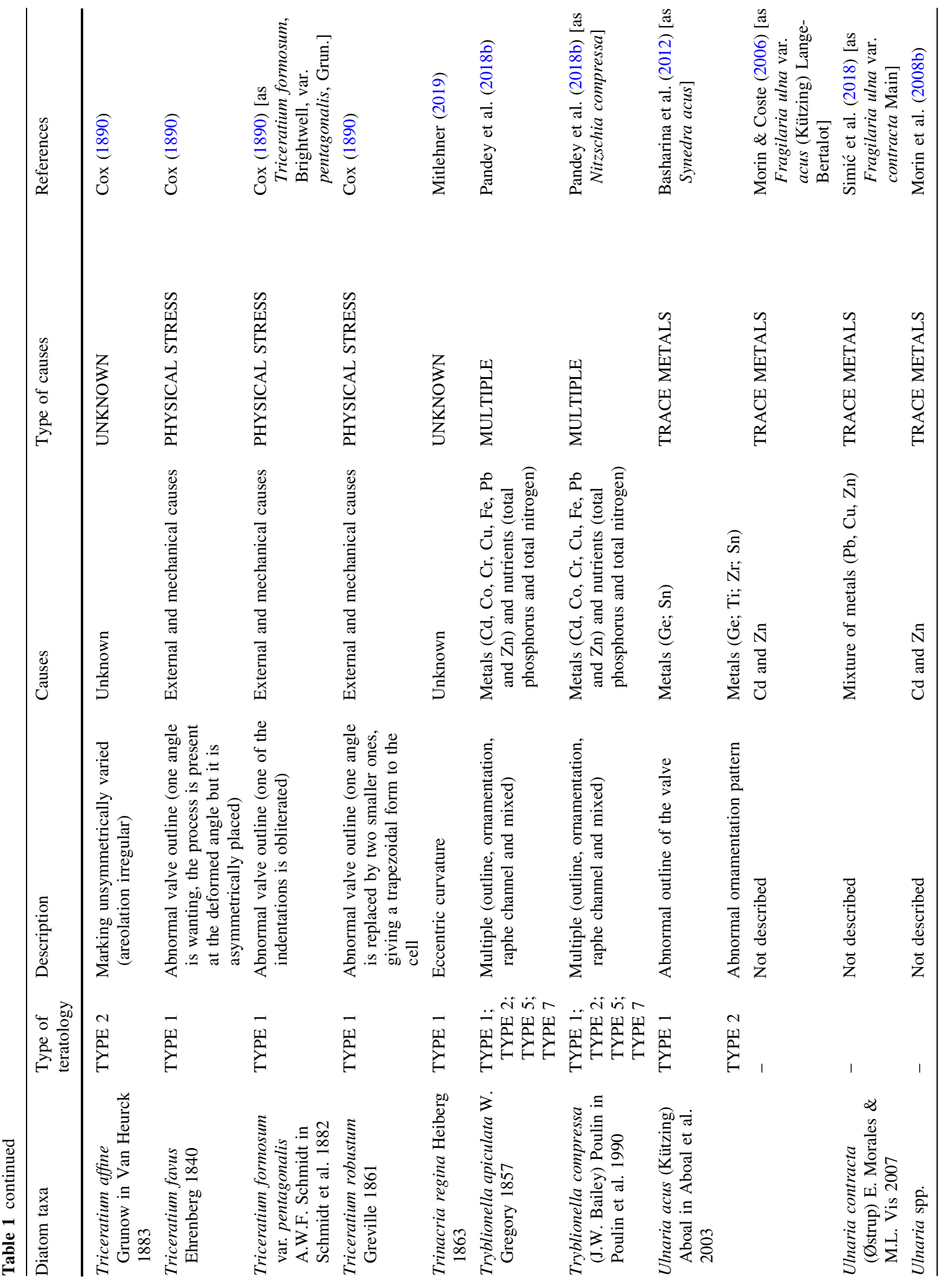




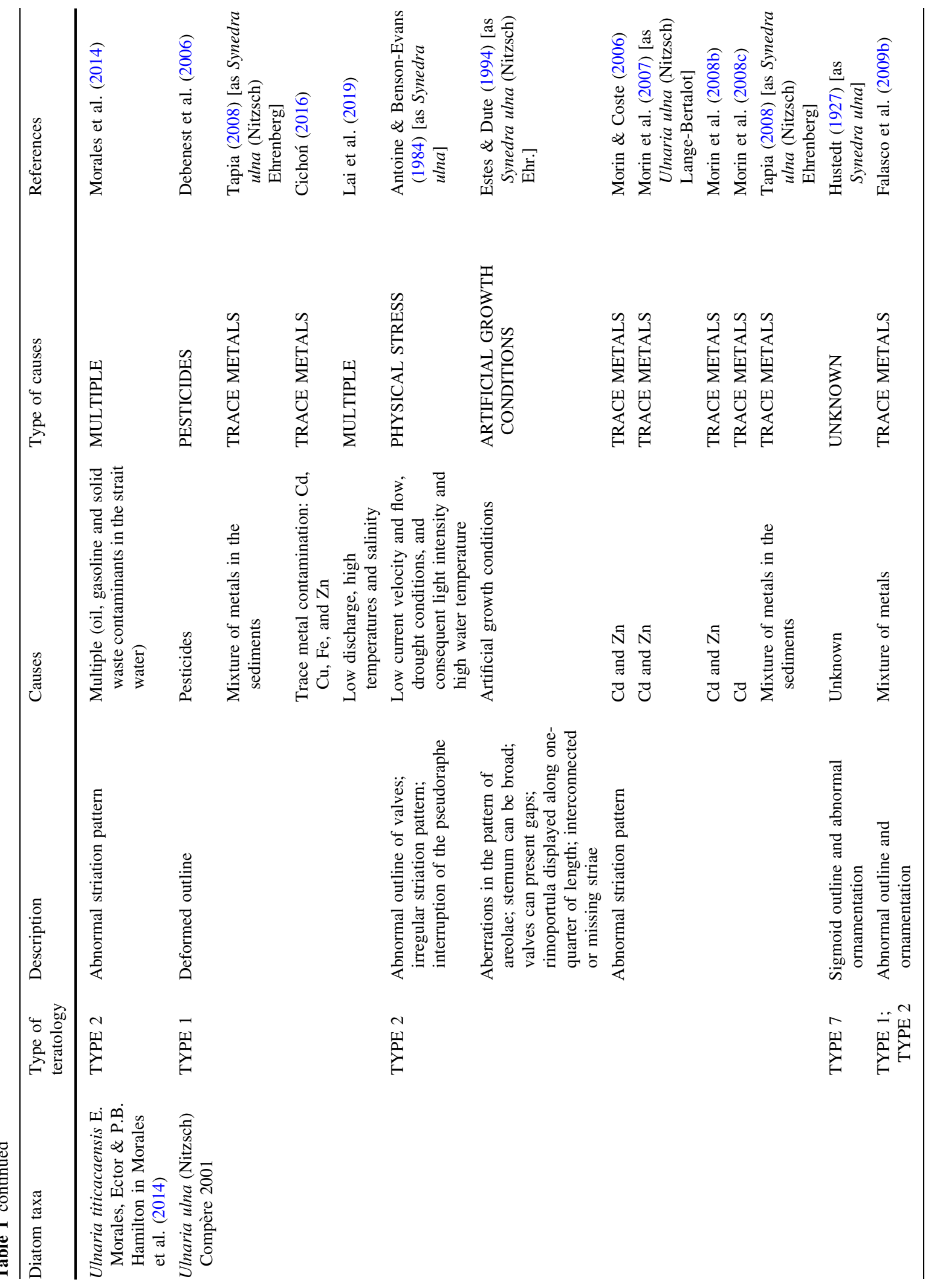




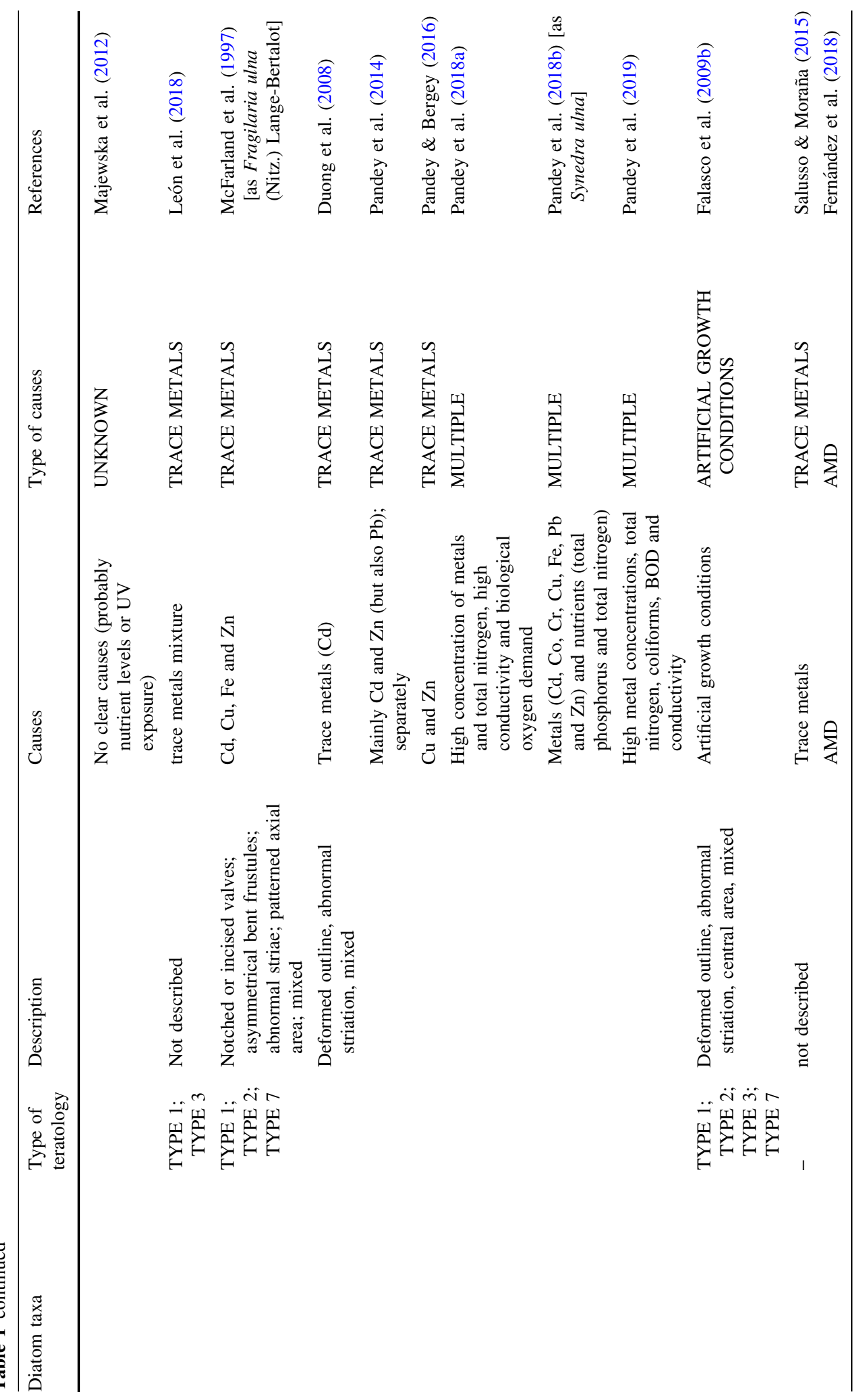


Which kind of stress teratological forms can assess?

Most of the research focussing on diatom teratologies suggested that abnormal form (presence/absence) detection is a good and reliable signal for the identification of an environmental stress. Deformity frequency ranging from 0 to $0.5 \%$ should be considered as naturally occurring (Morin et al., 2008a, 2012a; Arini et al., 2012b), while higher percentages can be considered warning signals of contamination. But the absence of deformity can help in the interpretation of certain results. This was the case of the research carried out by Tudesque et al. (2012), who tried to untangle the impact of toxicant and suspended solid load, when studying a gold mining impact. The absence of teratological forms in the samples led authors to state that the changes recorded in the diatom flora were mainly related to suspended solids load rather than trace metals.

Teratological forms can be considered one of the best early detection systems also to track past environmental conditions, as highlighted in many recent publications in the field of the paleolimnology. With this regard, diatom teratological forms have been encountered in a sediment core sample recovered from Młynek Lake (northern of Poland) and related to the increase of anthropogenic activities and nutrient concentrations starting from 1900 AD (Zalat et al., 2018). Cuna et al. (2014, 2015) observed teratological valves of Encyonema perpusillum (A. Cleve) D.G. Mann in Round et al. in a core sample of Lake Luna (central Mexico). This was probably caused by the exposure to high UV radiation, typical of the high mountain lakes characterized by very transparent waters. The presence of teratological forms in core sediments can also be related to water acidification and trace metal deposition (Hodgson et al., 2000; Greenaway et al., 2012). Fontana et al. (2014) observed Fragilaria crotonensis Kitton abnormal forms in a core sample dated 1988-2010 in the Guarapiranga Reservoir (Saõ Paulo State, Brazil). The presence of teratological forms was induced by copper sulphate that was used to face a cyanobacteria bloom in the reservoir. Also, high phosphorous concentrations can be responsible of teratological diatom formations, as demonstrated by Moos \& Ginn (2016), who detected high percentages of abnormal Staurosira construens
Ehrenberg in a core sample of Musselman Lake (Ontario, Canada).

One of the main issues related to the use of teratological forms in the environmental stress evaluation and to the development of a reliable index is that abnormal form production can be related to a wide range of stresses. However, in an optimistic perspective, this could also be considered an advantage. Figure 1 offers an overview of the different kinds of environmental stresses, which have been recognized as possible causes of the teratological forms production and the relative percentages of papers published in literature from 1890 up to date.

Based on our data (Falasco et al., 2009a and the present paper), we noticed that most of the teratological form detection has been observed under "TRACE METALS" contamination, accounting almost $29 \%$ of the published literature. It is noted that "MULTIPLE" stress is the second major cause (17\%) of teratological form production and includes two or more environmental stressors at the same time. Many sources of impact are included in this category: beside trace metal contamination, we grouped all those contaminations related to the industrial production (some new emerging pollutants such as pharmaceutical and toxic compounds in general), high nutrient concentrations, high conductivity and/or organic load, hydrological pressure (and the consequent low discharge, high temperatures and salinity). Under the category "UNKNOWN" (about 16\%), we grouped published papers in which it was not possible to hypothesize a clear cause for the teratological form development. "ARTIFICIAL GROWTH CONDITIONS" (almost $11 \%$ ) includes culture growth conditions of monospecific strains or communities, but also all those studies carried out under artificial controlled conditions in which teratologies developed also in the absence of impact (control conditions). Additionally, "PHYSICAL STRESS" (about 8\%) includes extreme life conditions (such as tides, subterranean environments, water turbulence), external and mechanical causes of damage, extreme or unstable life conditions, biofilm crowding, hydrological pressure and its consequences (such as increase in light intensity and water temperature), UV radiations. Acid Mine Drainage "AMD" $(5 \%)$ leads to peculiar environmental conditions characterized by low $\mathrm{pH}$ and high trace metal concentrations (generally as a mixture). The category "OTHER" (almost 5\%) deals with all those impacts 


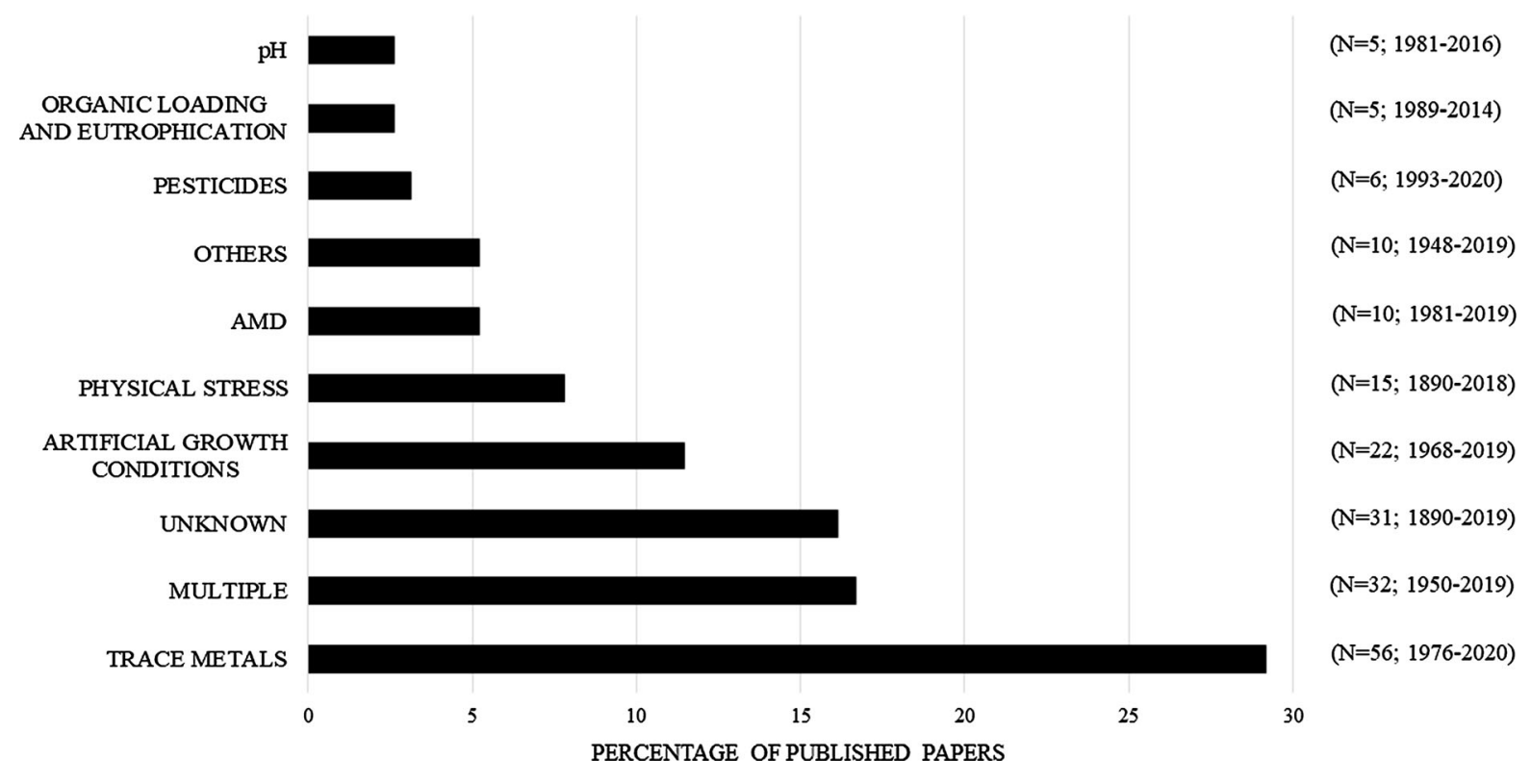

Fig. 1 Percentage of published papers relating teratological form production to a specific environmental stress

for which few observations were detected in literature and includes osmotic stress, silica limitation, experiments with microtubule inhibitors (such as colchicine), parasitism by fungi, exceeded lower limit for sexual reproduction, anti-biofouling paints, nutrient depletion and organic compounds. Other categories include "ORGANIC LOADING AND EUTROPHICATION" (almost 3\%) which includes mainly high nutrient or organic matter concentrations. Under the category "PESTICIDES" (almost 3\%) we included the fungicide thiram (dithiocarbamate), hydrocarbon emulsion, fluoranthene and isoproturon. In another category under "pH" (almost 3\%), we grouped studies mainly conducted in acid environments, even though in one case the possible cause of impact was recognized as alkaline waters $(\mathrm{pH} 8.5)$.

In the following sections, we provide an overview of the most recent published literature concerning some of the above-cited stress in relation to the production of abnormal forms.

\section{Trace metals}

Trace metal contamination in the water column is not an easily detectable parameter, especially when the effective concentrations are very low and the variability of runoff inputs and flow regime over time is high (Leguay et al., 2016). Water chemical analysis does not provide information concerning the bioavailable metal species (Pandey et al., 2014) and does not take into account the mixture effects of multiple trace metals on biota (Pandey et al., 2019). Moreover, intermittent pollution is difficult to assess through chemical analyses since the measurement should be performed exactly during the pollutant release (Lainé et al., 2014). On the contrary, extra- and intracellular trace metal content in the biofilm could provide important information on the severity and time frame of trace metal contamination. Intracellular trace metal concentration represents a good proxy of free metal ion gradient (Lavoie et al., 2012; Kim Tiam et al., 2018), even though internalization show different patterns and time frames depending on metal. Moreover, it is already known that the affinity of trace metals with the dissolved organic carbon (DOC) can cause ions complexation reducing metal bioavailability (Ahmed et al., 2013). Finally, intracellular concentration analyses are not easy to be carried out considering the costs and the equipment required and could be hardly included in the routine monitoring programs carried out by the Environmental Agencies.

The presence of trace metals in the environment strongly influences diatom health, so that either deficiency or excess of certain elements can lead to the cell death (see Masmoudi et al., 2013; Jones et al., 2018 for a review). In general, trace metal excess has 
more negative consequences on diatom life cycle, than metal scarcity, affecting diatom communities at different organization levels, from community structure to the individual level. Different metal stress-mediated mechanisms are activated to mitigate cell damages induced by trace metals. Diatoms can internally trap trace metals through glutathione and phytochelatins (Branco et al., 2010; Figueira et al., 2014) or excrete them in the external environment, with different efficiency degrees depending on species (Kim Tiam et al., 2019). In our previous review, basing on studies up to 2009 , we proposed the production of extracellular polymeric substances (EPS) as one of these defence tools. Following that hypothesis, EPS that contain carbohydrates with negatively charged groups could bind metal cations preventing trace metal adsorption. The protective role of EPS from various stressors, such as metal toxicity, has been supposed in many publications (Aguilera et al., 2008; Miao et al., 2009; Schröfel et al., 2011; Morin et al., 2012a; Naveed et al., 2019). Contrarily to this hypothesis, more recent works found opposite trends, observing a decrease of about 50\% EPS in diatoms exposed to cadmium (Cd; Santos et al., 2013). In that work, the authors described a new defence mechanism associated with the frustulins, a family of glycoproteins composing the valves. The cysteine-rich domain of these proteins contains sulfhydryl groups and would act as trace metal chelating agents on the cell surface (Santos et al., 2013). The protective role of EPS has been also recently disputed under experimental conditions by Chaumet et al. (2019), who tested toxicokinetic and toxicodynamic modelling of diuron under different flow conditions. However, evidence suggests that the thick and complicated 3D structure of mature biofilms forms a protective layer which limits the exposure of the inner zones to the external stressors and decreases toxicity of contaminants (Ivorra et al., 2000; Gold et al., 2003a, b). Concerning trace metal pollution, the protective effect of a thick matrix results in a less pronounced effect on primary production and community composition (Ivorra et al., 2000; Gold et al., 2003a, b). In this context, the microdistribution of diatoms within the biofilm, their growth forms and cell size can affect community responses to environmental stressors and deserve a deeper analysis (Ivorra et al., 2002; Morin et al., 2012a; Belando et al., 2017; Kiran Marella et al., 2020).
At a community scale, trace metal contamination selects for tolerant species which are generally represented by pioneer adherent taxa (Morin et al., 2012a), in particular by Achnanthidium minutissimum (Kützing) Czarnecki (Tapia, 2008; Luís et al., 2011; Olenici et al., 2017; Lavoie et al., 2019; Sivarajah et al., 2019; Pandey, 2020) but also Lemnicola exigua (Grunow) Kulikovskiy, Witkowski \& Pliński in Pliński \& Witkowski (Achnanthes exigua Grunow) (Pandey, 2020). However, many studies recognized as tolerant taxa also motile species such as nitzschioid diatoms (Pandey \& Bergey, 2018), Navicula cincta (Ehrenberg) Ralfs (Guasch et al., 2012), Nitzschia palea (Kützing) W. Smith or Mayamaea atomus (Kützing) Lange-Bertalot (Kim Tiam et al., 2019), high-profile species such as G. pseudoaugur (Gautam et al., 2017) or Hygropetra balfouriana (Grunow ex Cleve) Krammer \& Lange-Bertalot in Krammer (Lavoie et al., 2019). Generally, teratological forms in these kinds of resistant communities are rare (Cattaneo et al., 2004; Ferreira da Silva et al., 2009; Lavoie et al., 2012), even if exceptions sometimes occurred (Cantonati et al., 2014; Olenici et al., 2017). Achnanthidium minutissimum is one of the most frequent and abundant species, encountered worldwide (Wojtal et al., 2011 and references herein; Novais et al., 2015). Over the last decades, many researchers have been questioning the reliability of this taxon as a biological indicator, apparently due to its wide ecological range. Actually, the name A. minutissimum hides a complex of species, rarely distinguished in the past (Ector, 2011; Cantonati et al., 2014) due to its small dimensions and the few morphological characters useful for its identification. Recently, many attempts have been carried out to settle boundaries within this complex, also with the aim to strengthen the ecological information provided during the biomonitoring process (Novais et al., 2015). Indeed, this complex has been reported from alkaline to acidic, oligo- to hyper-trophic waters (Potapova \& Hamilton, 2007) and its tolerance to trace metal contamination is clearly documented (Kim et al., 2008; Falasco et al., 2009a, b; Tlili et al., 2011; Morin et al., 2012a; Cantonati et al., 2014; Leguay et al., 2016; Tolotti et al., 2019). The dominance of $A$. minutissimum in contaminated rivers, distinguished by its high reproduction rates and small dimensions, often led to wrong ecological status classification and unsuitable results when diatom indices are applied (Lainé et al., 2014). 
At individual scale, trace metals can lead to impairments of the cell metabolism, photosynthesis and homeostasis, which delay or inhibit diatom growth (Morin et al., 2012a; Mu et al., 2017); it can lead to a decrease of diatom biomass production, gene expression modification, impacts on the mitochondrial metabolism and formation of radical oxygen species (Morin et al., 2012a). Last but not least, and subject of this review, trace metals lead to individual morphological abnormalities, i.e. teratological forms. In our previous review (Falasco et al., 2009a), we already cited several studies which highlighted the existing relationship between trace metal contamination and the presence of teratological forms, and these results have been strengthened in the following years up to date (Tapia, 2008; Ferreira da Silva et al., 2009; Sierra \& Gómez, 2010; Ciszewski et al., 2011; Corcoll et al., 2012; Lavoie et al., 2012, 2018, 2019; Pandey et al., 2014, 2015, 2018b; Renzi et al., 2014; Laird et al., 2015; Salusso \& Moraña, 2015; Cichoń, 2016; Pandey \& Bergey, 2016, 2018; Sienkiewicz \& Gąsiorowski, 2016; Gautam et al., 2017; Mu et al., 2017; León et al., 2018; Simić et al., 2018; Kim Tiam et al., 2019). However, in many of the above-cited studies, the relationship between metal concentrations and teratology frequencies or abundances was not statistically corroborated, even when trace metal contamination appeared as the only potential cause of valve deformation. Indeed, especially under field conditions, the high variability, unpredictability and interaction of the environmental or chemical parameters can mask and confuse the linearity of such response of the diatom community. Moreover, multiple stressors can have cumulative (synergic or additive) effects, which can impair specific and different cellular functions, and not only the metabolic pathway involved in the valve formation. In addition, water chemistry (such as $\mathrm{pH}$, hardness, alkalinity and dissolved organic carbon) affects metal bioavailability (Fernández et al., 2018). Consequently, the same trace metal concentration can lead to different responses under different river chemical conditions, rendering the interpretation of the results difficult. Finally, species deformation proneness has to be taken into account during the interpretation of the results (Lavoie et al., 2017), and even within the same species, intraspecific variability can lead to different responses at the individual level (Santos et al., 2016) since natural selection in metal chronically contaminated areas can drive towards a more tolerant progeny. In a trace metal-contaminated site, teratological forms possibly appear already few days after the first contamination begins, confirming their potential as early detection biomarkers (Arini et al., 2013; Pandey et al., 2015; Kim Tiam et al., 2018; Pandey \& Bergey, 2018; Gonçalves et al., 2019).

Diatom teratological forms have been recently used in the assessment of nanoparticles toxicity in freshwater environments (Jia et al., 2019). This study conducted on Nitzschia frustulum (Kützing) Grunow in Cleve \& Grunow revealed that both titanium dioxide $\left(\mathrm{TiO}_{2}\right)$ and multi-walled carbon nanotubes (MWCNTs) have significant effects on cell growth. $\mathrm{TiO}_{2}$-NPs, in particular, resulted more effective than MWCNTs, inhibiting chlorophyll $a$ production and inducing the formation of teratological forms. These two materials have been largely used in different fields, finding application in contemporary industrial products from agricultural to medical and pharmaceutical, up to electronic ones. Consequently, tons of $\mathrm{TiO}_{2}$-NPs and CNTs have been recently released into the aquatic environment, with growing expected amounts in the future.

\section{Multiple stress}

Multiple stressors are among the most difficult kind of impact to study. Especially in lowland rivers, biological communities provide integrated responses over time to many environmental and chemical variables (such as nutrients and toxic compounds), resulting faster and cheaper than a blind chemical screening for a wide range of contaminants (Pandey et al., 2018a, b). In such environments, to discern the effect of a single pollutant is almost impossible. Recently, the composition of diatom assemblages and the presence of teratological forms were used to assess the presence of pharmaceutical compounds (mainly analgesics, antiinflammatories and antibiotics) in hydrologically unstable Mediterranean rivers (Tornés et al., 2018). In such environments, the combined effect of sewage inputs and hydrological alterations can be deleterious for the diatom communities, due to the low dilution capacity of these systems (Tornés et al., 2018). Under these conditions, diatom community tend to be homogeneous (regardless the river typology or geology) and composed of similar pollution tolerant taxa. Tornés et al. (2018) observed that even if abnormal diatoms were also found in unpolluted sites, possibly 
due to the hydrological stress, significantly higher percentage of deformed valves were related to the urban pollution. Similar results were obtained when testing the effects of olive mill wastewaters in Mediterranean streams subject to different degrees of hydrological alterations (Smeti et al., 2019). Olive mills wastewater consists in high phenolic content, as well as organic matter, ammonium, inorganic phosphorous, trace metals, suspended solids and low $\mathrm{pH}$. In these ecosystems, the hydrological intermittency plays an important role in the pollutants availability, which accumulate in the sediments with significant consequences on the biota, i.e. the production of high percentages of teratological valves in many diatom species, with particular regard to Fragilaria rumpens (Kützing) G.W.F. Carlson (Smeti et al., 2019). Also in this study, as already observed in previous ones, the unpolluted sites subject to hydrological stress were interested by teratological forms production, even though to a less extent.

In a recent review, multiple and not very clear causes such as trace metal pollution, boron (B) presence and anoxia were recognized as the main drivers of teratology development in several diatom samples collected in Russia (Barinova, 2017). Large amounts of teratological forms in diatom and green algae communities were detected in the Rudnaya River, one of the most polluted rivers in the Primorsky region (Russia; Medvedeva et al., 2012). In South Africa, teratological forms were detected in urban sites characterized by closeness to mine areas and high levels of COD (chemical oxygen demand; Walsh \& Wepener, 2009).

Many teratological diatoms were recorded under the extreme conditions characterizing the hypersaline lake of Laguna Blanca (South American Andean Mountains; Cabrol et al., 2007) or the thermo-mineral springs of Sardinia (Italy; Lai et al., 2019). In the first case, the combination of high UV radiation, high salt content (three times higher than sea water), the geothermal flux and the large supply of nutrients $(\mathrm{N}$ and $\mathrm{P}$ ) are the possible causes of teratological form development within the diatom community (Cabrol et al., 2007). In the case of Italian thermo-mineral springs, the causes have been identified as a combination of low discharge, high temperatures and salinity (Lai et al., 2019).

In a recent paper, Millan et al. (2020) found very high percentage of teratological forms (up to 26\%) in mineral springs affected by natural radioactivity (namely La Montagne and Mariol) in the French Massif Central. Radon concentration and the percentage of teratological forms in the communities were highly correlated; however, authors did not exclude a possible additive or synergic effect of other factors such as trace metal presence or the high salinity levels characterizing the sampling sites. In the Tiquina Strait at San Pablo de Tiquina (Los Andes Province, Bolivia), a mixture of oil, gasoline and solid waste contaminants in the water were recognized as the cause responsible for the presence of diatom teratological forms. One of the species illustrated in the paper, Ulnaria titicacaensis E. Morales, Ector \& P.B. Hamilton in Morales et al., showed abnormal striation pattern; however, only less than $1 \%$ of the population showed teratological valves (Morales et al., 2014).

\section{Artificial growth conditions}

It is already known that artificial growth conditions can induce teratological form development in many diatom species. Falasco et al. (2009b) analysed 17 long-term monospecific culture strains, belonging to different genera, and observed different proneness to teratology among the different species. The authors recognized A. minutissimum as one of the few species not producing teratological forms under these growth conditions, hypothesizing its possible use as target species for ecotoxicological tests (Falasco et al., 2009b). A more recent research conducted by Windler et al. (2014) rejected that hypothesis, showing that also A. minutissimum produces abnormal cells in long-term cultures, under certain conditions. The authors observed differences in cell morphology of strains cultivated in xenic and axenic conditions. In particular, both A. minutissimum and Cymbella affiniformis Krammer strains developed teratological individuals when cultivated in axenic conditions, hypothesizing a mutualistic role of bacteria on the diatom reproduction and/or valve synthesis. Suboptimal cultural conditions and long-term cultivation were, once more, recognized as the main cause of teratological form appearance in Frustulia curvata Kulichová \& Urbánková in Urbánková et al. (2015), Gomphonema gracile Ehrenberg (Cerisier et al., 2019; Coquillé \& Morin, 2019), Nitzschia sp. aff. dubiformis Hustedt and Nitzschia sp. aff. laevis Hustedt (Stachura-Suchoples et al., 2016) strains. The appearance of teratological individuals 
under artificial growth conditions represents an important limit to the laboratory ecotoxicological tests, since it represents a significant background noise masking the species response to a certain contaminant (Kim Tiam et al., 2019). For this reason, further research is needed to improve and optimize the conditions for long-term diatom cultivations.

\section{Physical stress}

In general, harsh conditions and unstable environments favour the development of teratological forms. This is the case of Nupela troglophila Falasco, C.E. Wetzel \& Ector in Falasco et al., an aerophilous species described for the first time in the touristic cave of Bossea Cave (NW Italy) (Falasco et al., 2015) and Humidophila gallica (W. Smith) R.L. Lowe, Kociolek, Q. You, Q. Wang \& J. Stepanek (Diadesmis gallica W. Smith), found in the Valporquero Cave (León, NW Spain) (Borrego-Ramos et al., 2018) and both showing teratological individuals. Subterranean environments present extreme conditions for the growth of the biofilm covering walls and speleothems that strictly depend on both artificial light systems and high percentages of humidity.

The peculiar features which characterize extreme environments such as high-altitude Andean lakes (i.e. very high levels of total solar and UV irradiation; Albarracín et al., 2015) or fumaroles (Angel et al., 2018) were identified as the possible responsible cause of diatom teratology formation. Extreme environmental conditions are also typical of brackish marshes and saline lakes, where physical parameters such as low current velocity and high light intensity might affect silica deposition on the valve surface, producing abnormal forms in the genus Cocconeis Ehrenberg and Mastogloia Thwaites ex W. Smith (Al-Handal \& Abdullah, 2010; Al-Handal et al., 2016).

Moreover, Clarson et al. (2009) observed that abnormal diatoms can also be induced by turbulence. Physical disturbance, such as shallow and transparent waters and the consequent high temperature, were the main hypothesized causes of the malformations observed in the epizoic diatom Falcula hyalina Takano (Donadel \& Torgan, 2016).

\section{Acid Mine Drainage}

Acid Mine Drainage (AMD) is considered one of the most harmful ecosystem issue related to trace metal pollution. Indeed, the tailing of the abandoned mines (such as pyrite, galena or sphalerite) usually encompasses high percentages of sulphide minerals containing reduced forms of sulphur. When exposed to water and air, these wastes release acid leaches (due to the transformation of sulphides into sulphuric acid) and trace metals, which easily percolate over and through the soil to reach watercourses. As a consequence, the sites affected by AMD present very low $\mathrm{pH}$ values $(\mathrm{pH}$ $2-4$ ), very high ionic strength and high dissolved metal loads, which can induce the production of diatom teratological forms (Luís et al., 2011, 2013, 2016; Jones et al., 2018). In order to quantify AMD impact, in 2018 Fernández et al. developed a new index based on diatom community (namely ICM, Índice de Contaminación por Metales), starting from the statement that AMD promotes the same pool of species independently of the geographical location of the studied area. The index formula took into account species tolerance to trace metal and species reliability as ecological indicators, obtained by using trace metal bioavailability and not trace metal concentration by itself. The authors found that some assemblages were significantly recurrent in sites affected by the highest AMD levels (with Pinnularia aljustrelica Luís, S.F.P. Almeida \& Ector in Luís et al. and P. acidophila G. Hofmann \& Krammer in Krammer as characteristic species). Pinnularia subcapitata W. Gregory and Eunotia exigua (Brébisson ex Kützing) Rabenhorst were found in heavily polluted waters, while $A$. minutissimum and Brachysira vitrea (Grunow) $\mathrm{R}$. Ross in Hartley were typical of intermediate trace metal pollution. It is hard to discern whether these assemblages were driven by the low $\mathrm{pH}$ levels or trace metal contaminations, however, this goes beyond the final aim of the index. The authors also tested the efficiency of including the percentages of teratological forms into the index calculation but they found out that the inclusion of this metric does not improve its accuracy. The authors justify this result with the different proneness of the species to deform under stress. This could be due to the adaptation of certain species to the AMD, which is generally considered a long-term disturbance. For instance, P. aljustrelica probably developed efficient resistance mechanisms 
for detoxification (such as trace metal exclusion and/or chelation), which prevent the formation of teratologies. Recently, Luís et al. (2019) detected a significantly low diatom diversity and the presence of specific bioindicators of acid- and metal-contaminated waters, such as $P$. aljustrelica, in sites affected by AMD (Alentejo Province, south of Portugal). Again, diatom species richness and diversity was very low in the acidic lakes located in the Łuk Mużakowa along the Polish-German border (Sienkiewicz \& Gąsiorowski, 2017). In these communities, many teratological valves of Eunotia spp. and Pinnularia gibba (Ehrenberg) Ehrenberg were recorded (Sienkiewicz \& Gąsiorowski, 2017, 2019).

\section{$p H$}

Low $\mathrm{pH}$ levels were recognized as the single possible cause of teratological form development in a study conducted at vent sits in the Aeolic Islands (Rogelja et al., 2016), as well as in a small dystrophic lake in Poland (Grabowska et al., 2014). In a recent past, diatom teratological forms have also been used for identifying and tracking those areas affected by acid precipitations, such as the Great Smoky Mountains National Park (USA) (Furey et al., 2009). Indeed, many headwater streams in this area, even if free from any type of pollution from sewage or industry wastes, received atmospheric pollution from acid precipitations. In sites characterized by low $\mathrm{pH}$ and high levels of aluminium (Al), barium $(\mathrm{Ba})$ and manganese $(\mathrm{Mn})$, the percentages of deformed Eunotia subarcuatoides Alles, Nörpel \& Lange-Bertalot were particularly high, creating growing interest of the researchers monitoring the phenomenon.

\section{Organic loading and eutrophication}

Toxic compounds are not the only responsible factor of teratological forms development, but from 2009 only two studies hypothesized nutrients as the main responsible of abnormal diatom production. Straub et al. (2014) found significant percentages of teratological forms mainly related to the intensive agriculture and urbanization, which characterize some area in the Vaud County (Switzerland). Again, Beauger et al. (2016) found abnormal Sellaphora labernardierei Beauger, C.E. Wetzel \& Ector in Beauger et al. in samples collected in a spring characterized by slightly acidic $\mathrm{pH}$, high conductivity, calcium and nitrates derived from agricultural activities. Even though trace metal concentrations were not measured during that study, the authors hypothesized that nutrients were the most probable factor inducing teratologies.

\section{Pesticides}

The response of diatom communities to pesticide contamination was particularly active field of research in the first years of the 2000s. In a review published in 2010, Debenest et al. (2010) examined the effects of pesticides on diatom communities at different levels: from the intracellular toxic effects involving the organelles, to the impairments of the cell metabolism, from the effects on diatom growth, to the community composition alterations. The response of diatoms to these toxic compounds can vary depending on both the herbicide mechanism of action and community composition, with different sensitivity levels depending from species to species, and the presence of a sort of community adaptation, when the exposure to the herbicide is chronic (Larras et al., 2012). Recently, noteworthy percentages of diatom teratological forms were observed in communities exposed to thiram (35 and $\left.170 \mu \mathrm{g}^{-1}\right)$ and a hydrocarbon emulsion $(0.01$, $0.4,2,20 \mathrm{mg} \mathrm{l}^{-1}$ ) during ecotoxicological studies performed in outdoor mesocosms (Bayona et al., 2014).

New insights in the mechanisms involved in cell formation and teratological forms development

In a recent review, Hildebrand et al. (2018) investigated the process of diatom cell wall formation exploring both the spatio-temporal dynamics and interactions among components. Cell walls are composed of amorphous silica, a physically robust structure. Depending on the external environmental concentration, silicic acid can pass across cell membranes through free diffusion or by means of silicon transporters (SITs). Valve formation consists of two steps: first, the formation of a 2D structure composed of a very flexible basal layer; second the thickening of the valve through a 3D deposition of silica. In general, the first step is very fast and can be completed in 8-15 min depending on the species (Hazelaar et al., 2005). In this phase major features of ornamentation can be sketched, but still present an irregular shape; 
these elements are finally better defined during the second step (Hildebrand et al., 2018). The formation of the silica structures is located in the silica deposition vesicles (SDV) that are surrounded by a membrane called silicalemma composed of silica-associated proteins and long chain polyamines. SDV are strictly associated to the cytoskeleton, which provides a rigid path for SDV expansion and defines the correct positioning of the components within the valve. It has been hypothesized that SDV are kept in position not only through microtubules connections, but also to the participation of transmembrane proteins called cingulins (Tesson et al., 2017; Bedoshvili et al., 2018). Valve morphogenesis is a complex process, which can be described as a combination of micro- and macromorphogenesis. The micromorphogenesis controls the development of pore fields and areolae velum and should be mainly related to the SDV content, silicalemma and neighbouring plasmalemma. Macromorphogenesis is mediated by cytoskeleton (and as a consequence by the SDV position) and internal organelles.

The mechanisms involved in the teratological form development are, nowadays, still unknown, but they likely involve both cytoskeleton alterations and/or the impairment of the silicon metabolic pathway. As already discussed in our previous paper, abnormal frustule formations could be the result of nuclear alterations (such as dislocation, micronucleus formation, nucleus fragmentation and nucleus membrane breakage) which can be induced through the exposition to toxic compounds and can present significantly higher percentage of occurrence in strongly impacted urban sites (Nicolosi Gelis et al., 2020). Based on the hypotheses of Debenest et al. (2008), nucleus alterations would disrupt part of the diatom cytoskeleton involved in the migration of important components for cell wall formation, leading to the development of teratological forms. Recently, these results were in part contradicted by Licursi \& Gómez (2013), who observed a significant correlation between abnormal nucleus location and membrane breakage in microcosms treated with hexavalent chromium, but they did not observe teratological forms at all. However, the role of cytoskeleton in the valve morphogenesis has been highlighted by many experiments conducted with microtubule inhibitors, which generally impede macromorphogenesis (Bedoshvili \& Likhoshway, 2019). Cells treated with microtubule inhibitors, such as colchicine, showed abnormal ornamentation patterns, anomalies in the valve outline, curved or displaced raphe, and unusual raphe channel (see Bedoshvili et al., 2018; Bedoshvili \& Likhoshway, 2019 and references within). Cytoskeleton inhibitors can also affect finer structures of the valve such as fultoportulae or areolae.

Recent studies pointed out that polycyclic aromatic hydrocarbon (PAH), and in particular Benzo[a]pyrene, impairs silicon metabolic pathway of the diatom Thalassiosira pseudonana Hasle \& Heimdal through a decreasing expression of two genes involved in the frustule formation (the silicon transporter 1 and silaffin 3), which leads to the decrease of the available silica into the cells (Carvalho et al., 2011). These results were also confirmed by Kim Tiam et al. (2018) who showed a strong down regulation of the silicon transporter (sit) under Cd contamination, which would lead to a decrease in the silica uptake. Olenici et al. $(2018,2019)$ proposed two different hypotheses to explain the mechanisms involved in the production of a new type of teratology involving the valvocopulae (see "Identification and classification of the diatom teratologies" section). The first dealt with the weak extent of silicification of the girdle bands and the related problems arising during the vegetative reproduction (which generally lead to valve size reduction under trace metal contamination). The second hypothesis dealt with the above-cited cingulins, since mediated by a zinc-dependent system. When $\mathrm{Zn}$ exceeds into the water, it may affect the metabolic pathway related to the silica, damaging girdle bands.

Reproduction capacity and viability of teratological cells

Another important issue deals with the viability and reproductive success of teratological individuals. In recent years, Cox (2010) discussed on the importance of the valve morphogenesis and wall structures in diatom systematics. The author underlined that while some structural features of the diatom valve are highly consistent among groups, other features are more often subject to variation in response of particular environmental changes, and these changes likely confer success to the species under such conditions. In our previous review, we hypothesized that cells affected by abnormalities are probably disadvantaged in natural environment and doomed to disappear. We 
supposed that viability of abnormal diatoms could be also related to the type of teratology involved. For instance, raphe disruption could lead to lower viability and reproductive capacity, especially in natural environment where adhesion ability of the cell is essential (Falasco et al., 2009b); contrarily, striae and mixed deformations probably enable cells to survive and reproduce (Arini et al., 2013). Some evidence supported our thesis and showed that during a decontamination process, the percentages of teratological forms in samples affected by the highest levels of $\mathrm{Cd}$ were less abundant, than those collected in the less impacted ones (Arini et al., 2013). The authors hypothesized that populations exposed to higher trace metal contaminations were more damaged and, likely, less viable than the other ones. Contrarily to our idea, a recent experiment carried out on culture strains of G. gracile led to different results (Coquillé \& Morin, 2019). Under the same artificial conditions, teratological strains of G. gracile showed growth rates similar to normal individuals and presented comparable photosynthetic efficiency and mobility. As presented in Lavoie et al. (2017), results from unpublished studies suggest that teratological individuals of Asterionella formosa Hassall under artificial condition did not seem to have a reduced fitness.

Pandey \& Bergey (2016) observed lower motility rate in species colonizing severely polluted sites (contaminated by $\mathrm{Cu}$ and $\mathrm{Zn}$ ) than less polluted ones; in addition, diatoms in the less contaminated site followed straight curved or sigmoid paths, while erratic and random under higher pollution. However, as evidenced in a recent paper, parameters related to motility are difficult to be interpreted since highly variable even within the same genus (Nicolosi Gelis et al., 2020). Even though, culture conditions offer a less harsh environment than natural rivers and streams, where flow plays a key selective role, these studies recently suggested the evolutionary success of the teratological forms. Considering this, a question arises: why are the percentages of abnormal individuals so low in natural conditions? Indeed, especially during decontamination processes, we should expect a similar reproductive success of normal and teratological cells. The answer is likely related to the continuous contribution of normal diatoms drifting from the upstream sections, serving as a source, and that can mask the presence of teratological individuals at the polluted site just downstream (Coquillé \& Morin,
2019). Indeed, diatom migration, especially from drift, has been recognized as one of the main mechanisms involved in the diatom community recovery or colonization process (Morin et al., 2012b; Falasco et al., 2018a).

Identification and classification of the diatom teratologies

As already pointed out in our previous review, an important issue for the inclusion of teratological forms in the application of diatom indices is related to the subjectivity of the analysts and the microscopical resolution involved in the determination whether an individual can be considered normal or deformed. To overlook teratological individuals and to exclude them from the inventories can lead to significant mistakes in watercourses quality assessment and classification. To confirm this, a recent study carried out by Olenici et al. (2020) demonstrated that specific pollution index (SPI) can be significantly overestimated when teratological individuals are excluded from the counting (up to 8 units in samples where abnormalities are abundant) masking the environmental pressures impacting the sampling sites. The mistaken identity of a teratological form can also lead to significant errors such as the description of new species. This was the case of Planothidium victori Novis, Braidwood \& Kilroy whose valves were described as "rotationally asymmetric to a variable degree [..], from almost linear to slightly curved near one pole to incised near one pole to form a hook" while they were just teratological individuals belonging to the genus Planothidium Round \& Bukhtiyarova (Novis et al., 2012; Wetzel et al., 2019b). Recently, some authors tried to overcome identification mistakes by means of specific tools such as the geometric morphometric analyses. For instance, Cerisier et al. (2019) demonstrated that a simplified approach (i.e. by using a limited numbers of landmarks, just six, optimally positioned on the valve outline) was sufficient to preserve the discriminating power of the geometric morphometric analysis, that resulted in a statistically significant method for the discrimination of normal/abnormal valves. Moreover, for some species it was possible to detect a gradient of deformations generally associated to the increasing level of $\mathrm{Zn}$ contamination. This approach could potentially be employed in the diatom automated identification which is currently under development. 
Similar results were obtained by Olenici et al. (2017) who found the geometric morphometric approach to be a good discriminatory analysis to distinguish abnormal and normal frustules of A. minutissimum and Achnanthidium macrocephalum (Hustedt) Round \& Bukhtiyarova.

A first attempt to classify teratologies was proposed by Falasco et al. (2009b). In that study, seven different types of teratologies were recognized and described basing on the results obtained from field and laboratory experiments. The authors observed that the most frequent and abundant teratology recorded under natural conditions was the deformation of the valve outline. Many other structural deformations were observed, but mainly in cultures. Abnormal valve outline, indeed, is easily transmitted through generations as the mother valve serves as a template for the following generations; on the contrary, any other alterations involving the ornamentation patterns are not. Moreover, the authors hypothesized that teratologies affecting ornamentations probably need more time to develop, and this could be the reason of the minor frequency of records in natural environments.

The attempt to classify teratological forms arose from the need to answer the question if deformities are toxicant specific or not. Lavoie et al. (2017) tried to solve this question and observed that trace metals exposure, such as herbicide, generally induce valve deformations, while other non-toxic causes can also lead to high percentages of mixed teratologies. Olenici et al. (2017) noticed that species belonging to $A$. minutissimum sensu stricto and A. macrocephalum, presented a different type of teratology when exposed to the same trace metal contamination (mainly $\mathrm{Zn}$ and $\mathrm{Cu}$ ). In particular, while abnormal individuals of $A$. minutissimum presented deformities involving mainly the apices, $A$. macrocephalum abnormalities involved the whole outline. In both laboratory and field studies, Pandey et al. (2015) and Pandey \& Bergey (2016) observed a dominance of type 4 teratology (affecting raphe slit) in periphytic communities exposed to $\mathrm{Cu}$ and $\mathrm{Zn}$, while Pandey et al. $(2014,2015)$ reported prevalence of abnormal striations and mixed deformities under Zn stress. Recently, Kim Tiam et al. (2019) observed that raphe related deformities (which they classified as "early morphogenesis deformities") generally affected $\mathrm{Cd}$ tolerant species, such as $N$. palea and $M$. atomus, that appeared more resistant to valve outline deformation or striae alterations.
Contrarily, mixed teratologies were mainly observed in $\mathrm{Cd}$ sensitive species, i.e. Pinnularia mesolepta (Ehrenberg) W. Smith. After the publication of Falasco et al. (2009b), many researchers started to group teratological forms in the proposed types, even though some authors moved constructive criticisms to this classification, observing that type 3 of teratology (abnormal or displaced central area) should be included in type 2 (abnormal striation pattern) since they are strictly dependent on one another (Pandey et al., 2014; Pandey \& Bergey, 2016). Considering the promising results obtained with this classification, we use the present publication to try to better define the type of teratologies through an identification key (Fig. 2).

Most types of teratology are fully described in Falasco et al. (2009b). Type 1 involves valve outline, which can result as more or less deformed and lose its typical symmetry/asymmetry depending on the species. In the present paper we want to pose the attention on the so-called "cymbelliclinum-like" teratology, mainly involving A. minutissimum sensu lato, and likely induced by the contamination of two trace metals (copper and zinc) and one metalloid (antimony) (Cantonati et al., 2014). Valves presenting this kind of deformation show one or even both bent off apices (Fig. 3). A similar species has been recently described by Wetzel et al. (2019a) and named Achnanthidium peetersianum C.E. Wetzel, Jüttner \& Ector in Wetzel et al.

After its description, the same teratology has been recognized by other authors (Cerisier et al., 2019; Tolotti et al., 2019) and associated to trace metal contamination. In many cases, the analysed assemblages showed also a very low biodiversity, and few accompanying species were detected (mainly belonging to the genus Fragilaria Lyngbye, that also deformed). Despite involving the valve outline, we strongly believe this kind of teratology should be considered as a reliable and sure marker of trace metal contamination, since our idea has been supported by many personal observations (record of this specific teratology in river flowing in mining areas, unpublished data). For this reason, we divided it from the type 1 teratology, creating a specific sub-class. Type 2 affects pattern and structure mainly of striae and costae, which can appear disordered in their orientation and organization, as well as constitution (loss or unusual shape of the areolae forming the striae). Type 


\begin{tabular}{|c|c|c|}
\hline 1a & colony & 2 \\
\hline $1 b$ & 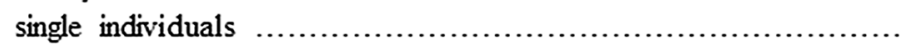 & 3 \\
\hline $2 \mathrm{a}$ & normal disposition of the individuals within the colony $\ldots \ldots \ldots \ldots \ldots$ & NO TERATOLOGY \\
\hline $2 b$ & unusual arrangement of the cells forming the colony .................. & TYPE 6 \\
\hline $3 a$ & deformed valve outline & 4 \\
\hline $3 b$ & normal valve outline............. & 5 \\
\hline $4 a$ & absence of any other kind of deformation involving the valve $\ldots \ldots .$. & TYPE 1 \\
\hline $4 b$ & note and record if a clear "cymbelliclinum-like" shape is & \\
\hline & recognizable (generally affecting Achnanthidium minutissimum).... & TYPE 1A \\
\hline $4 \mathrm{c}$ & presence of other structural deformation (no matter which one) ..... & TYPE 7 \\
\hline $5 a$ & abnormal valvocopula.. & 6 \\
\hline $5 b$ & normal valvocopula..... & 7 \\
\hline $6 a$ & absence of any other kind of deformation involving the valve......... & TYPE 8 \\
\hline $6 b$ & presence of other structural deformation (no matter which one) ...... & TYPE 7 \\
\hline $7 \mathrm{a}$ & 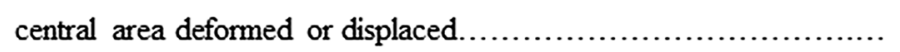 & $\mathbf{8}$ \\
\hline $7 \mathrm{~b}$ & 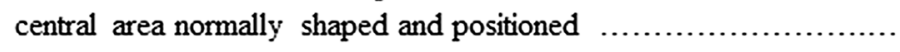 & 9 \\
\hline $8 a$ & $\begin{array}{l}\text { normal striation in pattern and structure, normal raphe/raphe } \\
\text { channel; the alteration involves uniquely the central area } \\
\text { (very rare typology) }\end{array}$ & TYPE 3 \\
\hline $8 b$ & presence of other structural deformation (no matter which one)........ & TYPE 7 \\
\hline $9 a$ & abnormal striation pattern and structure & 10 \\
\hline $9 b$ & 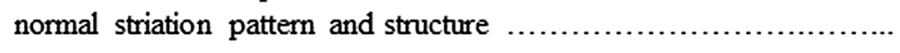 & 11 \\
\hline $10 \mathrm{a}$ & presence of other structural deformation (no matter which one)....... & TYPE 7 \\
\hline $10 \mathrm{~b}$ & 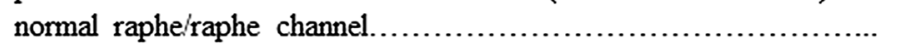 & TYPE 2 \\
\hline $11 \mathrm{a}$ & abnormal raphe/raphe channel....... & 12 \\
\hline $11 b$ & 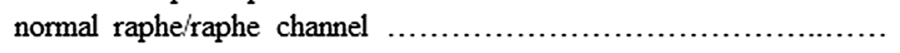 & NO TERATOLOGY \\
\hline $12 a$ & abnormal raphe........ & TYPE 4 \\
\hline $12 b$ & normal raphe channel. & TYPE 5 \\
\hline
\end{tabular}

TYPE 1: Deformed valve outline

TYPE 2: Changes in striation pattern, costae and septae

TYPE 3: Changes in shape and position of the central area (doubled o displaced central area)

TYPE 4: Raphe modifications

TYPE 5: Raphe canal modifications

TYPE 6: Unusual arrangement of the cells forming colonies

TYPE 7: Mixed type (more than one teratology at the same time on the same cell)

TYPE 8: Abnormal valvocopula

Fig. 2 Key for the identification of the diatom teratologies 

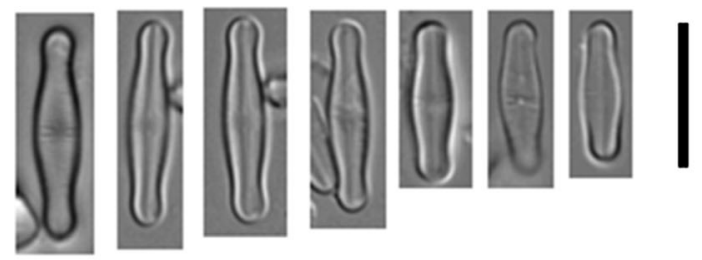

\section{a-g}
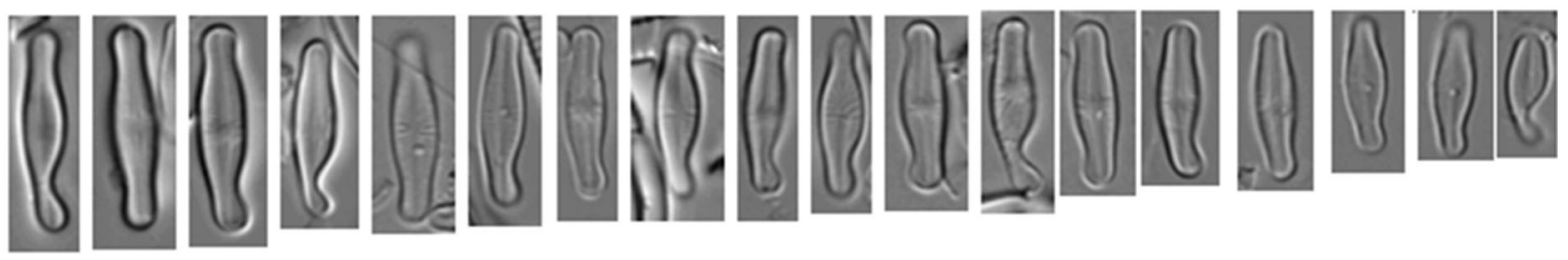

h-y

Fig. 3 Normal (a-g) and abnormal (h-y) individuals of Achnanthidium minutissimum sensu lato displaying the "cymbelliclinum-like" teratology. Samples were collected in the

3 is quite rare and affects central area of the valve, leaving the pattern of striation normal. This is mainly the case of Planothidium species, for which the central area often appear deformed, displaced, or doubled. In some cases, the number of teratological diatoms bearing this type of alteration was so high and the modification so constant in its structure, that some authors identified the teratological individuals as new species. This is the case of Achnanthes lanceolata var. bimaculata described by Hustedt in 1950, which presents a doubled central area with a doubled hood. The same species was identified as an initial cell of $A$. lanceolata (Brébisson ex Kützing) Grunow in Cleve \& Grunow by Geitler in 1977. Finally, it was described again as a new taxon by Bukhtiyarova in 2017, under the name of Planothidium bilensis Bukhtiyarova. However, type 3 teratology can also affect Ulnaria (Kützing) Compère or Fragilaria species, where central area is sometimes displaced and moved towards the apex. Type 4 and 5 respectively involve raphe slit and raphe channel, which appear displaced, interrupted, doubled or forked. Type 6 is recorded when an unusual disposition of the cells forming a colony is observed. Type 7 is the "mixed" category, including two or more teratologies affecting the same valve at the same time. In the present paper, we add to these previously described typologies also the type 8 . Recently recognized and described by Olenici et al. $(2018,2019)$ this new type 8 of teratology involves the
Saint Marcel River (Aosta Valley, NW Italy), that flows in Saint Marcel Valley, known to host in the past several $\mathrm{Cu}$ and $\mathrm{Mn}$ mines

cingulum and was observed in some individuals belonging to the A. minutissimum complex. In particular, the valvocopula of these individuals appeared undulated.

After the analysis of the existing relationships between type of teratology and type of contamination (Lavoie et al., 2017), in the present paper we propose the hypothesis that the type of teratology could have a relation with the structure of the valve itself. To do this, basing on the literature analysis, we pose the attention on which types of teratologies affect each diatom genera (see Electronic Supplementary Material 1). Figure 4 shows the most frequently recorded genera and relative proportions of the types of teratologies observed.

We start with a simple consideration, i.e. the more complex the valve structure, the greater type of deformations can potentially be involved. Indeed Stephanodiscus Ehrenberg, with its simple radial symmetry and ornamentation, just shows two types of deformations including outline and striation pattern. Araphid diatoms, such as Diatoma Bory, Fragilaria, Staurosira Ehrenberg, Tabularia (Kützing) D.M. Williams \& Round and Ulnaria present mainly three types of deformations, involving the outline (TYPE 1), the pattern of striation (TYPE 2) or both of them at the same time (TYPE 7). Displaced longitudinal or central area were also observed, but in few cases. Based on our literature data, no unusual shape of the colonies 


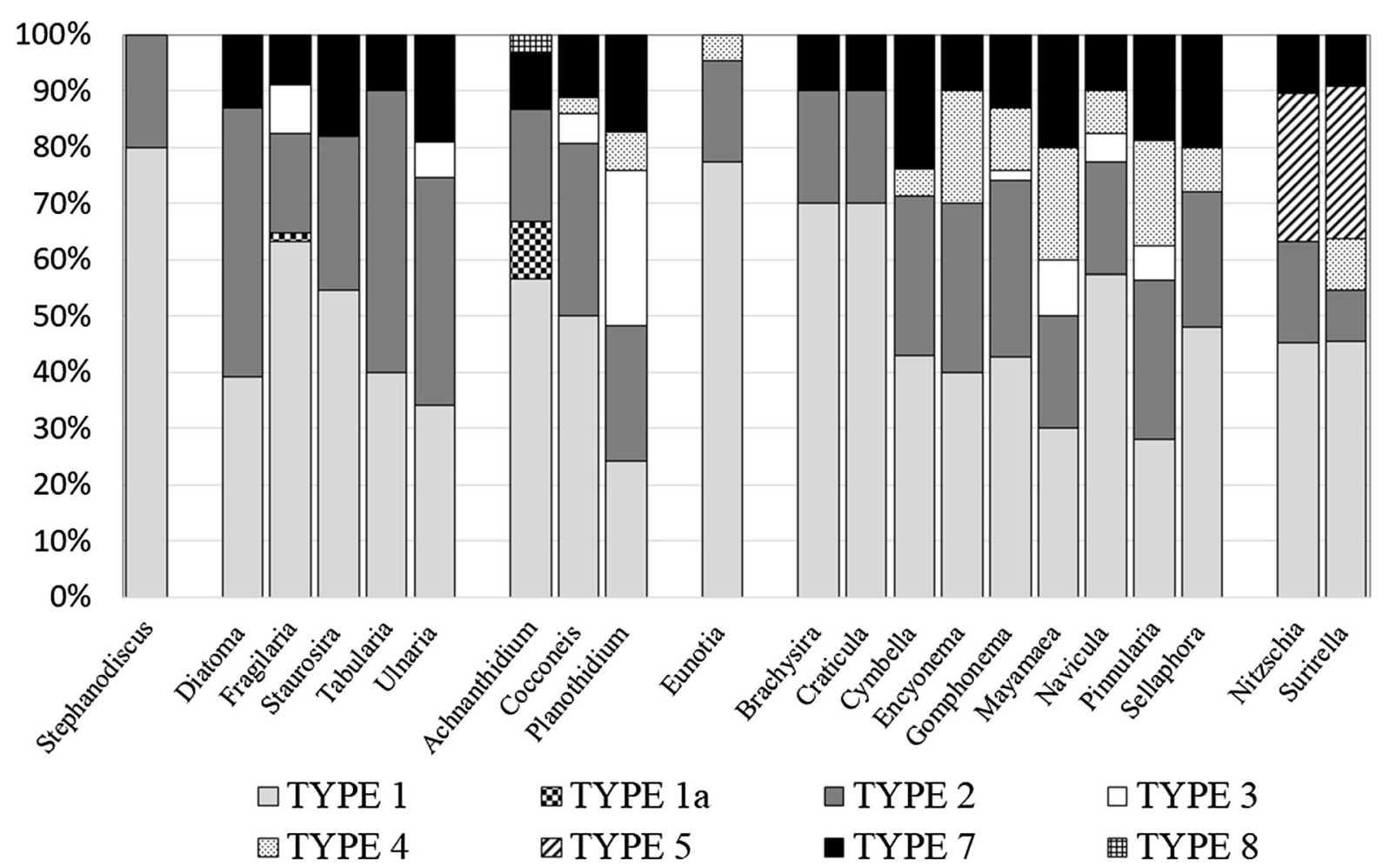

Fig. 4 Most common diatom genera and types of teratology affecting them, based on literature data (Falasco et al., 2009a and the present paper). Teratology type 6 is excluded from the figure since none of the examined genera presented an unusual arrangement of the individuals forming a colony

2004; Morin \& Coste, 2006; Arini et al., 2013). In this genus, raphe slit is also subject to abnormalities. Eunotia is a biraphid diatom whose raphe slits lie on the valve mantle and it is characterized by absent longitudinal and central areas. In the literature, the only teratologies encountered in Eunotia species are those involving valve outline, striation patterns and raphe; no mixed typology has ever been observed. Finally, biraphid diatoms display the most of the described type of teratologies. Interestingly, in these genera, the alteration of the raphe slit or, when present, the raphe canal, have been often recorded. In Nitzschia, type 5 teratology involving the raphe canal is much more frequent than type 4 (abnormal raphe slit) in all the other genera, where the keel is absent.

Functional responses at community level

In recent years, many authors obtained encouraging results and advantages by using a functional approach 
(i.e. exploring the response of several metrics, such as diatom cell size, growth forms and ecological guilds) for the evaluation of the ecological status of water bodies (Rimet \& Bouchez, 2012; Falasco et al., 2018b; Nicolosi Gelis et al., 2020). The evidence, herein, led us to take into consideration the approach in the framework of contamination assessment and the consequent production of teratological forms. In particular, in this review, we tried to answer the following questions: is there a size dependency in teratological form development? Does a specific environmental stress preferentially induce teratological forms in a certain group of diatom class size and/or life forms and/or ecological guilds?

Preliminary results addressing the first question were already obtained by Arini et al. (2012c), who hypothesized a diatom size dependency in teratological form development. Indeed, the authors observed severe teratologies at LM involving especially largesized diatoms [such as Navicula lanceolata (C. Agardh) Kützing or N. gregaria Donkin, more than small-sized ones (such as E. minima and M. atomus)]. However, it is also important to take into account that teratologies involving valve ornamentation or raphe system are obviously more visible in larger individuals, than in small ones, for which scanning electron microscopy (SEM) analyses is the only way to detect them. Indeed, throughout SEM analysis Morin et al. (2014) found a significant percentage of teratological forms affecting small diatom species and a decrease in cell biovolume in trace metal-contaminated sites.

In order to answer the second question, we reviewed the literature concerning diatom teratological forms and the above-cited environmental stress (see Fig. 1) under a functional perspective, i.e. by analysing data considering class sizes, life forms and ecological guilds. The results of this analysis are shown in Fig. 5. Please note that, considering the heterogeneity of the data sources, and the different statistical meaning of the relative results, we decided not to perform any statistical analysis on them, but just to draw some general considerations. Moreover, we excluded from this section species for which no sure data concerning class size and ecological guild were provided in Rimet \& Bouchez (2012).

The "AMD" mostly affects small-sized taxa (SIZE $1+$ SIZE 2 account together more than $60 \%$ of the cases), generally belonging to the high-profile and motile guilds (Fig. 5b). We can explain this result if we consider that AMD generally produces a long-term impact and likely favours small species and communities characterized by low total biovolume (Pandey et al., 2017 and references herein). Contrarily, "ARTIFICIAL GROWTH CONDITIONS" conditions lead higher percentages of deformations in medium-large sized diatoms (SIZE 3-4-5 accounted for the $75 \%$ of the total observations, with equal proportions), mainly belonging to the high-profile, stalk and motile guilds. Under these conditions, adnate and pad-attached species demonstrated to be resistant and do not deform; on the contrary, stalked and motile taxa were the most affected and showed teratologies. Although culture conditions can mimic natural environments, some parameters such as artificial light, nutrient depletion, metabolic wastes produced by the strain and in some case the absence of water flow, likely create a physical stress for the cell growth. Lowprofile species easily adapt to these stressful conditions, especially those concerning light and low nutrients, and probably deform less in comparison to the other ecological guilds and life forms. Similar conclusions can be drawn for the stress category "PHYSICAL DISTURBANCE". Indeed, also in this case, large species (SIZE 5 representing $47 \%$ of the observations) belonging to the high-profile guild result as the most affected classes and easily deform. On the contrary, very few observations were recorded concerning stalked diatoms, which seem to be less subject to deformation under physical disturbance than under artificial growth conditions. We can easily explain this if we consider that stalked taxa in natural environment are the most sensitive group to physical disturbance and simply disappear. Other differences in diatom response to "ARTIFICIAL GROWTH CONDITIONS" and "PHYSICAL DISTURBANCE" can be explained if we consider that most of the studies conducted under artificial conditions assume the growth of monospecific strain and excludes the interspecific competition that naturally characterizes the periphyton dynamics. The "TRACE METALS" and "MULTIPLE" stressors show the same pattern, inducing teratologies in high-profile and motile guilds more than low profile and planktonic. Few differences were observed when analysing the affected class sizes, with multiple stress inducing teratology in biggersized diatoms (SIZE 5). We can hypothesize that these kinds of stresses, and especially the multiple contamination, are mainly characteristic of lowland rivers 


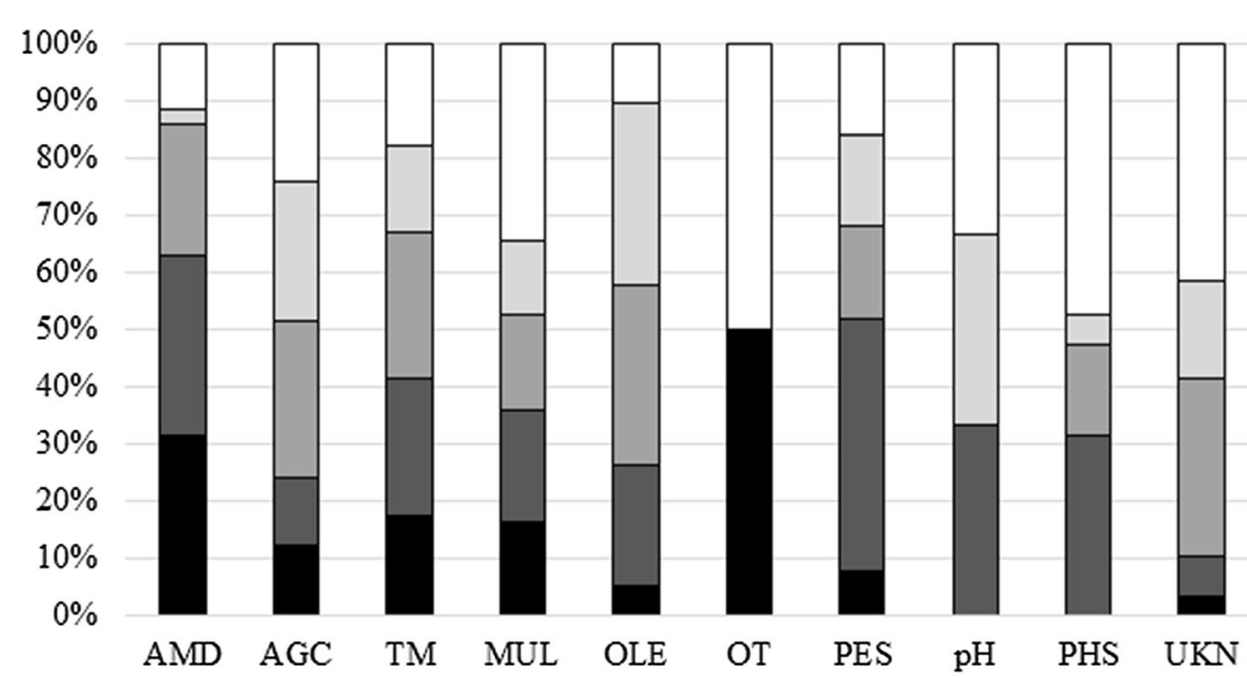

(a)

- SIZE 1

口SIZE 2

口SIZE 3

$\square$ SIZE 4

口SIZE 5

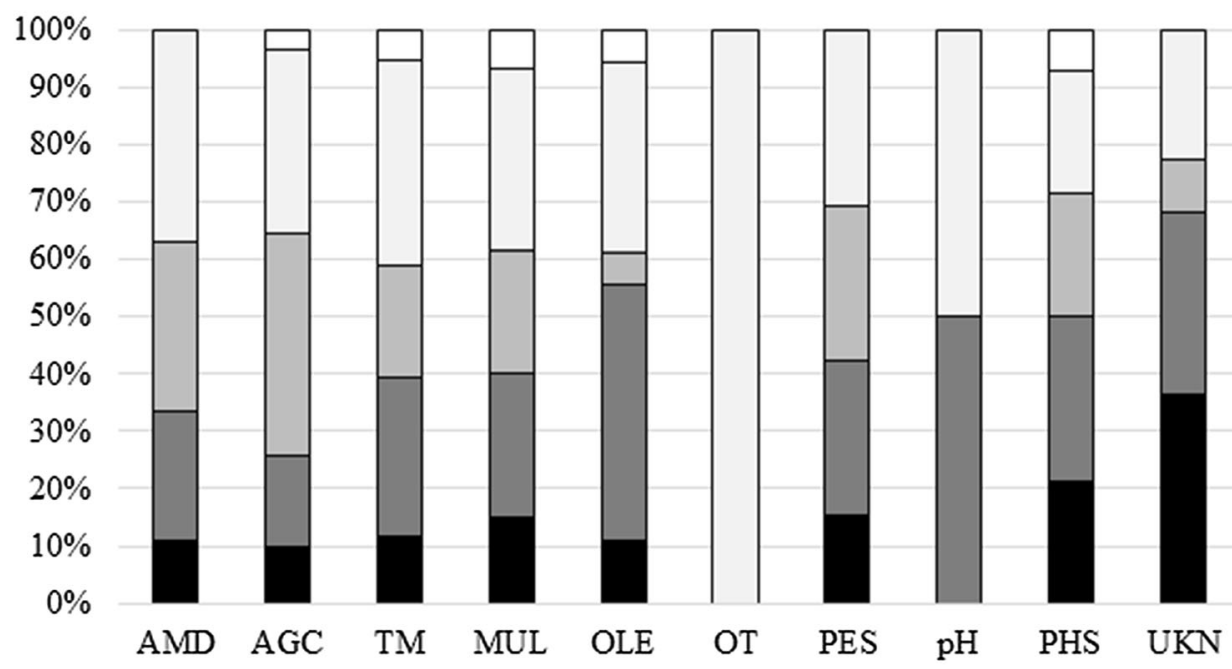

(b)

- Adnate

$\square$ Pad

口Stalk

$\square$ Motile

$\square$ Planktonic

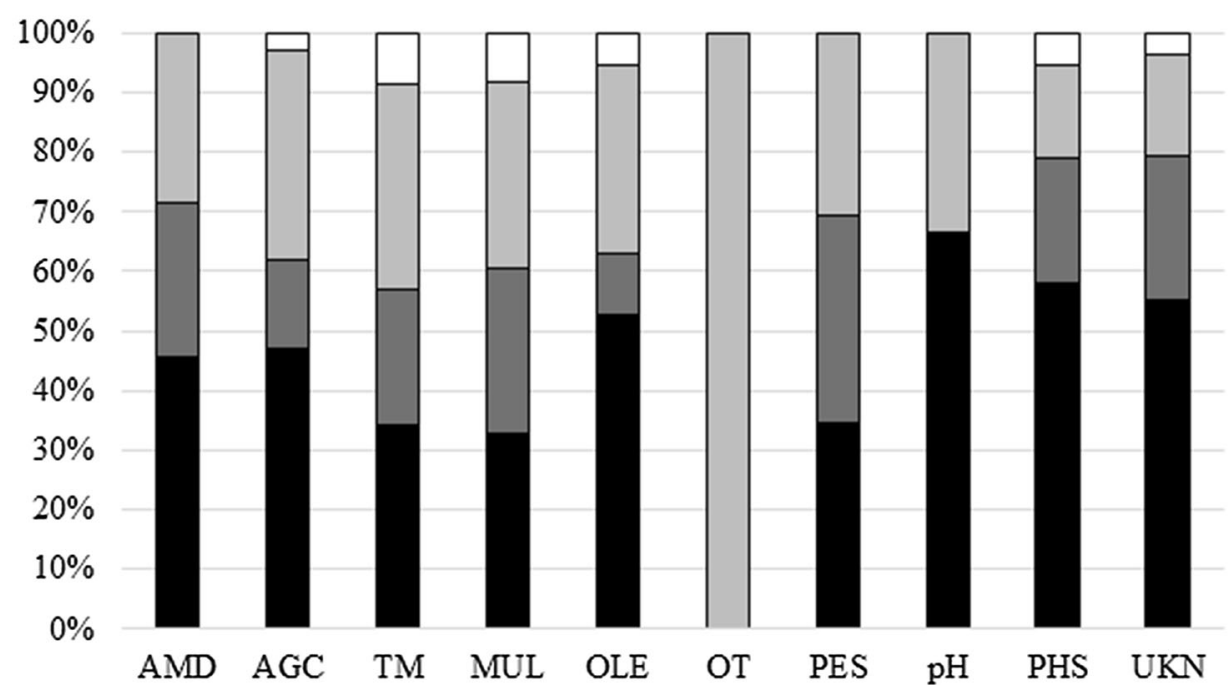

(c)

- High profile

$\square$ Low profile

$\square$ Motile

$\square$ Planktonic 
4Fig. 5 Percentage of teratologies induced by specific environmental causes and acting on different diatom class sizes (a) life forms (b) and ecological guilds (c). AMD Acid Mine Drainage, $A G C$ artificial growth conditions, TM trace metals, $M U L$ multiple, $O L E$ organic loading and eutrophication, $O T$ others, $P E S$ pesticides, $p H \mathrm{pH}, P H S$ physical stress, $U K N$ unknown

where nutrients are not a limiting factor and larger species are favoured. The category "PESTICIDES" induces deformations mainly in small-sized species (class size 2). This stress seems to affect in the same way both ecological guilds and life forms, since no differences within these two groups were observed. The "pH" category appears to affect both small and large species in the same way. However, low $\mathrm{pH}$ seems mainly to affect pad-attached and motile guilds, while no observation was recorded on taxa belonging to the low-profile guild, whose species never show deformations. The category "ORGANIC LOADING AND EUTROPHICATION" generally affects medium-sized diatoms, pad-attached and belonging to the high-profile and motile guilds, in accordance with the general definition of the ecological guilds. Low-profile taxa are simply disadvantaged in these kinds of environments and less represented within the community, so they deform less.

\section{A four-step procedure for data interpretation}

The considerations we have just made in the previous section, on the functional responses at the community level, must be interpreted with caution and discussed taking account other aspects, such as the structure of the biofilm subject to the stress; the type and percentage of guilds showing teratological species; the species composition; and the taxa proneness to deform. The same stress likely has different effects on a pioneer community composed of only low-profile species or on a well-developed 3D mature biofilm. This is also, in our opinion, one of the reasons for which many different and, sometimes, contrasting results appear often in the literature. To focus uniquely on single species responses, appears to be insufficient. Indeed, it is already well known that a thick mature biofilm can be considered as a shelter for the lower layers (Ivorra et al., 2000; Licursi \& Gómez, 2013), which can be less susceptible to trace metal contamination (Duong et al., 2010) or herbicides (Tabak et al.,
2007; Franz et al., 2008). In this section, we propose a four-step procedure that, through the analysis of different scenarios, could be used by researchers to comment results deriving from future research (Fig. 6).

First, researchers have to take into consideration the percentage of teratological forms within a community. We have already seen in a previous section that percentages ranging from 0 to $0.5 \%$ should be considered as naturally occurring, while higher values mostly indicate an environmental stress.

Second, biofilm structure gives us information concerning the maturity and stability of the biofilm and, as a consequence, of the diatom community. Very thin biofilms are generally composed of only lowprofile guild, and can represent either a recently settled community (a first stage of colonization after a strong perturbation events, such as flood) or a mature community resource-stressed but disturbance free (i.e. experiencing nutrient and light limitation, but resisting to physical disturbance). This is the case, for instance, of a typical community inhabiting a mountain stream (subject to both high-flow velocity and low-nutrient loads). When a contamination event affects these kinds of communities, the low-profile guild is directly involved since no upper layer is present to provide a shelter. If teratological forms appear in this context, we can probably exclude the physical stress as source of disturbance, since lowprofile species are already naturally adapted to face this kind of pressure, mainly due to their growth form (adnate, prostrate, erected). We can hypothesize and we can exclude a high-nutrient load from the sources of disturbance, since low-profile species would not survive under these conditions (with the exception of few taxa). Trace metal, AMD or toxic compounds are among the most probable source of contamination. Communities composed of only high-profile or motile guilds are rare, but existing. In the case of the sole high-profile guild, the species would be resourceunlimited but disturbance-stressed. Considering this, we should add to the possible source of stress also those related to the scarcity of nutrients or to the physical disturbance, in particular grazing activities or siltation (and the consequent light limitation). We would exclude scouring since high-profile species would not survive under these conditions. Among the ecological guilds, the motile one is free from both resource limitation and disturbance stress, since it is 


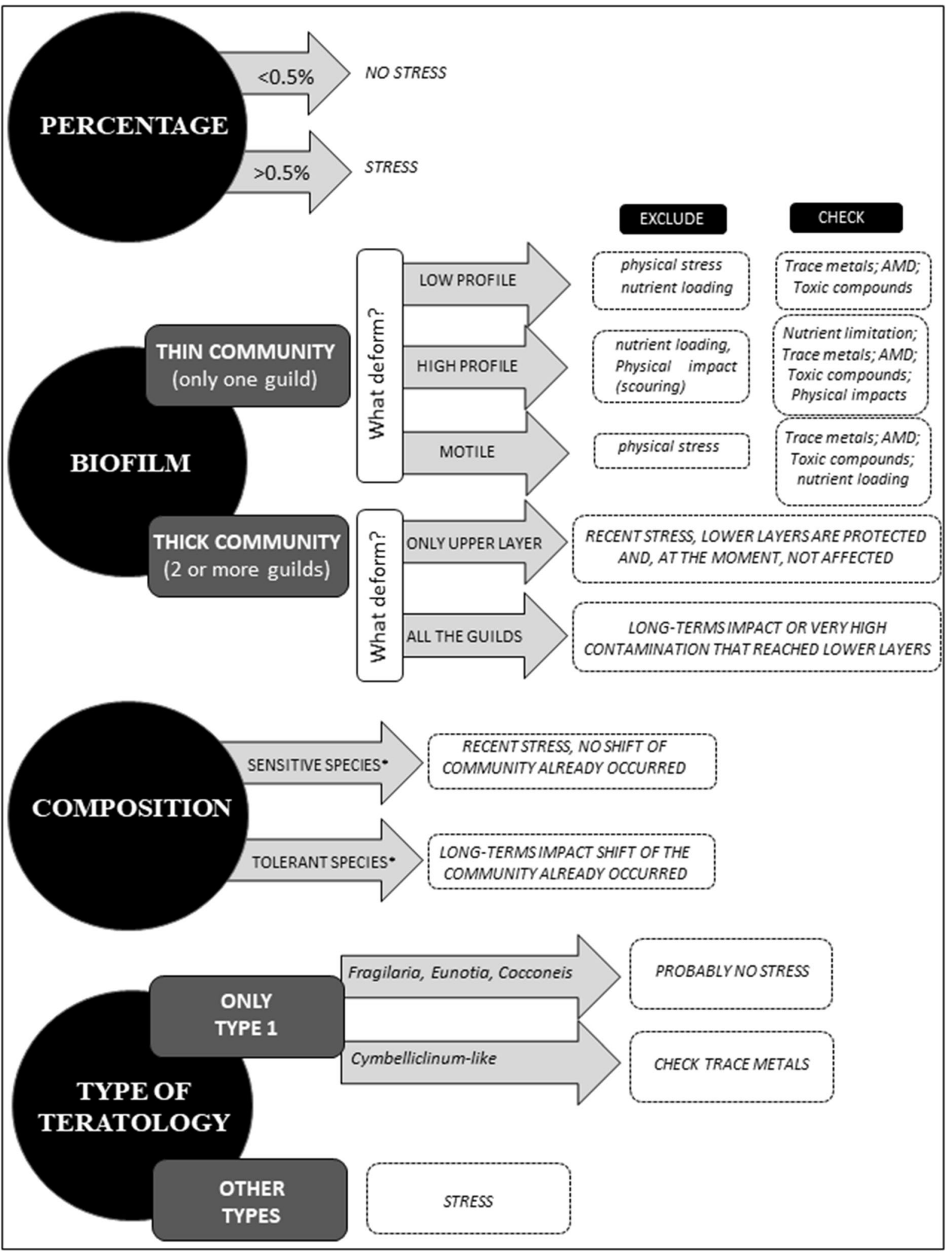


4Fig. 6 Four-step procedure which includes the analysis of different biofilm features and scenarios. *See Morin et al. (2012a) and Wood et al. (2019)

able to move relatively fast and exploit most suitable habitats. This guild is usually the most representative in the epipelon. The presence of teratological forms in this kind of community would probably mean that species are tolerant to that kind of stress and the contamination is chronic.

All these considerations should be revised when the involved biofilm present a well-developed 3D architecture that, basing on several ecological and ecotoxicological papers, may exert a protective role on the deeper layers. In that case, the percentage of guilds presenting teratological individuals can provide important information concerning the time of exposure to a certain stress. From a theoretical point of view, high-profile species are the most exposed to the source of stress, extending beyond the boundary layer. Contamination would affect this guild first. Indeed, motile species can easily move through the biofilm to escape the source of disturbance. Low profile would be the last group affected by the stress, being protected by the upper layers. Therefore, time of exposure can be recent when only one guild present teratological individuals (mainly high and motile), or long term if all the guilds are affected, since possibly the source of stress was able to pass through the whole biofilm. There is a further possibility for which, among the 3D biofilm, only the low-profile guild shows deformed individuals. In this case, we could hypothesize that an acute stress took place in the past, affecting only lowprofile guilds, afterwards, in the absence of stress, the colonization continues and upper layers settled. Under these conditions, low-profile species, both normal and teratological ones, continue to reproduce even though the stress has ceased. In this case, the teratology would provide a track of a past stressful event.

Community composition can also provide important information on the exposure time of the contamination, especially when the pollution concerns trace metal or herbicides for which some studies on species sensitivity already exist (see Morin et al., 2012a; Wood et al., 2019). If only sensitive species are present, and some of them deform, we can deduce the pressure is recent, since no shift in the diatom community composition towards tolerant taxa was already possible. On the contrary, when tolerant taxa are composing the community, we can hypothesize the chronic nature of the contamination.

The possible different meaning of the type of teratologies in the context of the environmental biomonitoring has been already explored by Lavoie et al. (2017). The authors believe that certain genera (namely Fragilaria and Eunotia, but also Cocconeis, personal observation also confirmed by Al-Handal \& Abdullah, 2010; Al-Handal et al., 2014) are more prone to produce teratological forms than other when affected by a certain kind of disturbance and, as a consequence, they should be considered as less reliable than other taxa in the context of the environmental contamination assessment. The same authors also hypothesized that deformed valve outline (namely type 1) should be considered a less reliable teratology than other types. Abnormal valve outline, indeed, is transmitted through the generations in an easier way than the other types of teratology. In this context, we think it should be taken into account also the reproduction strategy of the different diatom genera. Indeed, if type 1 teratology could be overestimated when affecting a ruderal species with high reproductive rates, this could be less true in secondary colonizers.

\section{Conclusions}

This paper intends to give continuity to a project started in 2009 and fruitfully pursued in 2017, when several issues related to diatom teratological forms were examined throughout the collaboration of many experts (Lavoie et al., 2017). Even though an index based on teratological forms is still far from being developed, we hope the present paper can help researchers in the interpretation of the results obtained from their future research. The four-step procedure we proposed in this article is based on theoretical hypotheses, and most of the readers certainly know that natural processes are never so linear in their responses. Indeed, many other important issues necessarily need to be considered in the stress-response analysis. Among them, the interspecific competitions within diatom community and among the other primary producers inhabiting the biofilm, which could drive and shape species composition and induce the production of teratological forms. For instance, it has 
been recently demonstrated that allelopathic compounds produced by the cyanobacterium Nodularia spumigena Mertens ex Bornet \& Flahault induce the development of teratological forms in Bacillaria paxillifera (O.F. Müller) T. Marsson (ŚliwińskaWilczewska et al., 2016). Also, the biotic interactions among diatoms and biofilm decomposers, which share resources and space becoming important under extreme environments (such as trace metal pollution) need to be considered (Guasch et al., 2012). Other important issues are the reproduction strategy of the species belonging to the different ecological guilds, and least but not last, the proneness of the single species to deform. All these aspects and many others deserve consideration and further investigations in order to be included in the procedure.

Acknowledgements This study was carried out as part of the activities of ALPSTREAM, a research centre financed by FESR, Interreg Alcotra 2014-2020, EcO Project of the Piter Terres Monviso. This work is part of the Research Fellowship "Analisi delle diatomee bentoniche di fiumi piemontesi" won at UNITO by Dr. Falasco. Funding for this research was also provided in the framework of the Project DIATOMS (LIST_Luxembourg Institute of Science and Technology). The authors are grateful to Dr. Livia Mobili of the ARPA Valle d'Aosta for providing samples of the Saint Marcel River and to Dr. Bart Van de Vijver for his precious suggestions. The authors are particularly grateful to Dr. Diba Khan-Bureau, Professor at Three Rivers Community College (Norwich, Connecticut), for the revision of the English style of the entire manuscript.

Funding Open access funding provided by Università degli Studi di Torino within the CRUI-CARE Agreement.

Open Access This article is licensed under a Creative Commons Attribution 4.0 International License, which permits use, sharing, adaptation, distribution and reproduction in any medium or format, as long as you give appropriate credit to the original author(s) and the source, provide a link to the Creative Commons licence, and indicate if changes were made. The images or other third party material in this article are included in the article's Creative Commons licence, unless indicated otherwise in a credit line to the material. If material is not included in the article's Creative Commons licence and your intended use is not permitted by statutory regulation or exceeds the permitted use, you will need to obtain permission directly from the copyright holder. To view a copy of this licence, visit http://creativecommons.org/licenses/by/4.0/.

\section{References}

Ács, É. \& G. Lakatos, 1989. Preliminary algological study on biofouling in industrial water systems. Studia Botanica Hungarica 21: 5-12.

Adesalu, T. A., 2017. Freshwater diatoms diversity of national parks in Nigeria I: Okomu National Park, South-South, Nigeria. Ife Journal of Science 19(2): 269-281.

Adshead-Simonsen, P. C., G. E. Murray \& D. J. Kushner, 1981. Morphological changes in the diatom Tabellaria flocculos $a$, induced by very low concentrations of cadmium. Bulletin of Environmental Contamination and Toxicology 26(6): 745-748.

Aguilera, A., V. Souza-Egipsy, P. San Martín-Úriz \& R. Amils, 2008. Extracellular matrix assembly in extreme acidic eukaryotic biofilms and their possible implications in heavy metal adsorption. Aquatic Toxicology 88(4): 257-266.

Ahmed, I. A., J. Hamilton Taylor, S. Lofts, J. C. Meeussen, C. Lin, H. Zhang \& W. Davison, 2013. Testing copper-speciation predictions in freshwaters over a wide range of metal-organic matter ratios. Environmental Science and Technology 47: 1487-1495.

Albarracín, V. H, D. Kurth, O. F. Ordoñez, C. Belfiore, E. Luccini, G. M. Salum, R. D. Piacentini \& M. E. Farías, 2015. High-Up: a remote reservoir of microbial extremophiles in Central Andean wetlands. Frontiers in Microbiology 6: 1404 .

Aleem, A. A., 1950. Distribution and ecology of British marine littoral diatoms. Journal of Ecology 38(1): 75-106.

Al-Handal, A. Y. \& D. S. Abdullah, 2010. Diatoms from the restored Mesopotamian marshes, South Iraq. Algological Studies 133: 65-103.

Al-Handal, A. Y., C. Riaux-Gobin, D. S. Abdulla \& M. H. Ali, 2014. Cocconeis sawensis sp. nov. (Bacillariophyceae) from a saline lake (Sawa Lake), South Iraq: comparison with allied taxa. Phytotaxa 181(4): 216-228.

Al-Handal, A. Y., C. Pennesi \& D. S. Abdullah, 2016. Mastogloia abnormis sp. nov. and Mastogloia descrepata sp. nov. (Bacillariophyceae, Mastogloia section Sulcatae) from Sawa Lake, Southern Iraq. Diatom Research 31(2): 113-121.

Almeida, P. D., E. A. Morales, C. E. Wetzel, L. Ector \& D. C. Bicudo, 2016. Two new diatoms in the genus Fragilaria Lyngbye (Fragilariophyceae) from tropical reservoirs in Brazil and comparison with type material of $F$. tenera. Phytotaxa 246(3): 163-183.

Angel, A., I. Vila, C. Díaz, X. Molina \& P. Sepúlveda, 2018. Geothermal diatoms: seasonal variability in the El Tatio geothermal field (Altiplano, Chile). Advances in Microbiology 8: 211-234.

Antoine, S. E. \& K. Benson-Evans, 1983. Polymorphism and size variation in Didymosphenia geminata from Great Britain. British Phycological Journal 18: 199-200.

Antoine, S. E. \& K. Benson-Evans, 1984. Teratological variations in the River Wye diatom flora, Wales, U.K. In Ricard, M. (ed.), Proceedings of the Eighth International Diatom Symposium. Paris, August 27-September 1, 1984. Koeltz Scientific Books, Koenigstein: 375-384. 
Antoni, J. S., Y. Daglio, M. M. Areco \& M. C. Rodríguez, 2020. Zinc-induced stress on cells of Halamphora luciae (Bacillariophyceae). European Journal of Phycology. https://doi.org/https://doi.org/10.1080/09670262.2020. 1758961.

Arena, C. M., J. L. Galebach, T. M. Mandichak, J. M. Engle \& M. G. Anderson, 2014. Identification of diatoms in a healthy Pennsylvania stream compared to three downstream sites impacted by Abandoned Mine Drainage. Fine Focus 1(1): 29-38.

Arini, A., A. Feurtet-Mazel, R. Maury-Brachet, M. Coste \& F. Delmas, 2012a. Field translocation of diatom biofilms impacted by $\mathrm{Cd}$ and $\mathrm{Zn}$ to assess decontamination and community restructuring capacities. Ecological Indicators 18: 520-531.

Arini, A., A. Feurtet-Mazel, R. Maury-Brachet, O. S. Pokrovsky, M. Coste \& F. Delmas, 2012b. Recovery potential of periphytic biofilms translocated in artificial streams after industrial contamination ( $\mathrm{Cd}$ and $\mathrm{Zn})$. Ecotoxicology 21(5): 1403-1414.

Arini, A., A. Feurtet-Mazel, S. Morin, R. Maury-Brachet, M. Coste \& F. Delmas, 2012c. Remediation of a watershed contaminated by heavy metals: a 2-year field biomonitoring of periphytic biofilms. Science of the Total Environment 425: 242-253.

Arini, A., F. Durant, M. Coste, F. Delmas \& A. Feurtet-Mazel, 2013. Cadmium decontamination and reversal potential of teratological forms of the diatom Planothidium frequentissimum (Bacillariophyceae) after experimental contamination. Journal of Phycology 49(2): 361-370.

Bagmet, V. B., Sh. R. Abdullin, S. E. Mazina, A. Yu. Nikulin, V. Yu. Nikulin \& A. A. Gontcharov, 2020. Life cycle of Nitzschia palea (Kützing) W. Smith (Bacillariophyta). Russian Journal of Developmental Biology 51(2): 106-114.

Barber, H. G. \& J. R. Carter, 1981. Observations on some deformities found in British diatoms. Microscopy 34: 214-226.

Barinova, S., 2017. Aberrant forms of algae and bioindication of aquatic ecosystem state. International Journal of Oceanography and Aquaculture 1(3): 000117.

Basharina, T. N., E. N. Danilovtseva, S. N. Zelinskiy, I. V. Klimenkov, Y. V. Likhoshway \& V. V. Annenkov, 2012. The effect of titanium, zirconium and tin on the growth of diatom Synedra acus and morphology of its silica valves. Silicon 4: 239-249.

Bayona, Y., M. Roucaute, K. Cailleaud, L. Lagadic, A. Bassères \& T. Caquet, 2014. Structural and biological trait responses of diatom assemblages to organic chemicals in outdoor flow-through mesocosms. Environmental Pollution 192: 186-195.

Beauger, A., C. E. Wetzel, O. Voldoire, A. Garreau \& L. Ector, 2016. Sellaphora labernardierei (Sellaphoraceae, Bacillariophyta), a new epilithic species from French spring and four new combinations within the genus Sellaphora. Phytotaxa 260(3): 235-246.

Bedoshvili, Y. D. \& Y. V. Likhoshway, 2019. Cellular mechanisms of diatom valve morphogenesis. In Seckbach, J. \& R. Gordon (eds), Diatoms: Fundamentals and Applications. Wiley, Hoboken; Scrivener Publishing, Salem: 99-114.
Bedoshvili, Y., K. Gneusheva, M. Popova, A. Morozov \& Y. Likhoshway, 2018. Anomalies in the valve morphogenesis of the centric diatom alga Aulacoseira islandica caused by microtubule inhibitors. Biology Open 7: bio035519.

Belando, M. D., A. Marín, M. Aboal, A.J. García-Fernández \& L. Marín-Guirao, 2017. Combined in situ effects of metals and nutrients on marine biofilms: shifts in the diatom assemblage structure and biological traits. Science of the Total Environment 574: 381-389.

Bertrand, J., L. Ector \& J.-P. Renon, 2014. Diatomées des mares: Études préliminaires de l'écologie des mares permanentes et éphémères de la région Centre (France) [Diatoms in ponds: preliminary studies of the ecology of the permanent and ephemeral ponds in the region Centre (France)]. Journal de Botanique de la Société Botanique de France 66: 55-74.

Bes, D., L. Ector, L. C. Torgan \& E. A. Lobo, 2012. Composition of the epilithic diatom flora from a subtropical river, Southern Brazil. Iheringia, Série Botânica 67(1): 93-125.

Blank, G. S. \& C. W. Sullivan, 1983. Diatom mineralization of silicic acid. VII. Influence of microtubule drugs on symmetry and pattern formation in valves of Navicula saprophila during morphogenesis. Journal of Phycology 19(3): 294-301.

Bonet, B., N. Corcoll \& H. Guasch, 2012. Antioxidant enzyme activities as biomarkers of $\mathrm{Zn}$ pollution in fluvial biofilms. Ecotoxicology and Environmental Safety 80: 172-178.

Borrego-Ramos, M., S. Blanco \& A. Olenici, 2018. Diatoms from the Valporquero Cave (León, NW Spain), with the description of Germainiella legionensis sp. nov. Journal of Cave and Karst Studies 80(4): 181-189.

Branco, D., A. Lima, S. F. P. Almeida \& E. Figueira, 2010. Sensitivity of biochemical markers to evaluate cadmium stress in the freshwater diatom Nitzschia palea (Kützing) W. Smith. Aquatic Toxicology 99(2): 109-117.

Buczkó, K., E. K. Magyari, É. Soróczki-Pintér, K. Hubay, M. Braun \& M. Bálint, 2009. Diatom-based evidence for abrupt climate changes during the Late Glacial in the Southern Carpathian Mountains. Central European Geology 52(3-4): 249-268.

Bukhtiyarova, L.N., 2017. Planothidium bilensis sp. nov. (Bacillariophyta) from the small pond in Kyiv Megalopolis (Ukraine). International Journal on Algae 19(1): 41-50.

Cabrol, N. A., C. P. McKay, E. A. Grin, K. T. Kiss, E. Ács, B. Tóth, I. Grigorszky, K. Szabò, D. A. Fike, A. N. Hock, C. Demergasso, L. Escudero, P. Galleguillos, G. Chong, B. H. Grigsby, J. Zambrana Román \& C. Tambley, 2007. Signatures of habitats and life in Earth's high-altitude lakes: clues to Noachian aqueous environments on Mars. In: Chapman, M. (ed), The Geology of Mars: Evidence from Earth-Based Analogs. Cambridge University Press, Cambridge: 349-370.

Canter, H. M. \& J. W. G. Lund, 1948. Studies on the plankton parasites. I. Fluctuations in the numbers of Asterionella formosa Hass. in relation to fungal epidemics. New Phytologist 47(2): 238-261.

Cantonati, M. \& H. Lange-Bertalot, 2011. Diatom monitors of close-to-pristine, very-low alkalinity habitats: three new Eunotia species from springs in Nature Parks of the southeastern Alps. Journal of Limnology 70(2): 209-211. 
Cantonati, M., N. Angeli, L. Virtanen, A. Z. Wojtal, J. Gabrieli, E. Falasco, I. Lavoie, S. Morin, A. Marchetto, C. Fortin \& S. Smirnova, 2014. Achnanthidium minutissimum (Bacillariophyta) valve deformities as indicators of metal enrichment in diverse widely-distributed freshwater habitats. Science of the Total Environment 475: 201-215.

Carvalho, R. N., S. K. Bopp \& T. Lettieri, 2011. Transcriptomics responses in marine diatom Thalassiosira pseudonana exposed to the polycyclic aromatic hydrocarbon benzo[a]pyrene. PLoS ONE 6(11): e26985.

Cattaneo, A., Y. Couillard, S. Wunsam \& M. Courcelles, 2004. Diatom taxonomic and morphological changes as indicators of metal pollution and recovery in Lac Dufault (Québec, Canada). Journal of Paleolimnology 32: 163-175.

Cerisier, A., J. Vedrenne, I. Lavoie \& S. Morin, 2019. Assessing the severity of diatom deformities using geometric morphometry. Botany Letters 166(1): 32-40.

Chaumet, B., S. Morin, O. Hourtané, J. Artigas, B. Delest, M. Eon \& N. Mazzella, 2019. Flow conditions influence diuron toxicokinetics and toxicodynamics in freshwater biofilms. Science of the Total Environment 652: 1242-1251.

Chiappino, M. L., F. Azam \& B. E. Volcani, 1977. Effect of germanic acid on developing cell walls of diatoms. Protoplasma 93(2-3): 191-204.

Cholnoky-Pfannkuche, K., 1971. Abnormaler Formenwechsel von Nitzschia palea in Kultur. Nova Hedwigia 21: 883-886.

Cichoń, S., 2016. Diatoms in the ecosystem of river contaminated with heavy metals. Archives of Waste Management and Environmental Protection 18(4): 9-14.

Ciszewski, D., U. Aleksander-Kwaterczak, U. Kubsik, J. Kwandrans, A. Pociecha, E. Szarek-Gwiazda, I. Tłoczek, A. Waloszek \& E. Wilk-Woźniak, 2011. Interdisciplinary investigations of contamination effects of pond and stream waters and sediments in the Matylda catchment - an attempt to classification. In: Zieliński, A. (ed), Interdisciplinary Researches in Natural Sciences. Institute of Geography, Jan Kochanowski University, Kielce: 29-46.

Clarson, S. J., M. Steinitz-Kannan, S. V. Patwardhan, R. Kannan, R. Hartig, L. Schloesser, D. W. Hamilton, J. K. A. Fusaro \& R. Beltz, 2009. Some observations of diatoms under turbulence. Silicon 1(2): 79-90.

Coquillé, N. \& S. Morin, 2019. Fitness of teratological morphotypes and heritability of deformities in the diatom Gomphonema gracile. Ecological Indicators 106: 105442.

Corbella, C., V. Tonolli \& L. Tonolli, 1958. I sedimenti del Lago d'Orta, testimoni di una disastrosa polluzione cupro-ammoniacale. Memorie dell'Istituto Italiano di Idrobiologia 10: 9-50.

Corcoll, N., B. Bonet, S. Morin, A. Tlili, M. Leira \& H. Guasch, 2012. The effect of metals on photosynthesis processes and diatom metrics of biofilm from a metal-contaminated river: a translocation experiment. Ecological Indicators 18: $620-631$.

Cox, E. J., 1995. Morphological variation in widely distributed diatom taxa: taxonomic and ecological implications. In Marino, D. \& M. Montresor (eds), Proceedings of the 13th International Diatom Symposium, Italy. Biopress, Bristol: $335-345$.
Cox, E. J., 2006. Raphe loss and spine formation in Diadesmis gallica (Bacillariophyta) - an intriguing example of phenotypic polymorphism in a diatom. Nova Hedwigia 130: 163-176.

Cox, E. J., 2010. Morphogenetic information and the selection of taxonomic characters for raphid diatom systematics. Plant Ecology and Evolution 143(3): 271-277.

Cox, J. D., 1890. Deformed diatoms. Proceedings of the American Society of Microscopists 12: 178-183.

Cuna, E., E. Zawisza, M. Caballero, A. C. Ruiz-Fernández, S. Lozano-García \& J. Alcocer, 2014. Environmental impacts of Little Ice Age cooling in central Mexico recorded in the sediments of a tropical alpine lake. Journal of Paleolimnology 51(1): 1-14.

Cuna, E., M. Caballero, E. Zawisza \& C. Ruiz, 2015. Historia ambiental de un lago alpino en el centro de México (12302010). TIP Revista Especializada en Ciencias QuímicoBiológicas 18(2): 97-106.

Debenest, T., M. Coste, F. Delmas \& E. Pinelli, 2006. Les frustules déformés de diatomées benthiques et les pesticides : Le cas des pollutions agricoles dans les coteaux de Gascogne (Sud-Ouest de la France). Diatomania 10: 62-65.

Debenest, T., J. Silvestre, M. Coste, F. Delmas \& E. Pinelli, 2008. Herbicide effects on freshwater benthic diatoms: induction of nucleus alterations and silica wall abnormalities. Aquatic Toxicology 88(1): 88-94.

Debenest, T., J. Silvestre, M. Coste \& E. Pinelli, 2010. Effects of pesticides on freshwater diatoms. In: Whitacre, D. M. (ed), Reviews of Environmental Contamination and Toxicology, vol 203. Springer, New York, pp 87-103.

De Jonge, M., B. Van de Vijver, R. Blust \& L. Bervoets, 2008. Responses of aquatic organisms to metal pollution in a lowland river in Flanders: a comparison of diatoms and macroinvertebrates. Science of the Total Environment 407(1): 615-629.

Dickman, M. D., 1998. Benthic marine diatom deformities associated with contaminated sediments in Hong Kong. Environment International 24(7): 749-759.

Donadel, L. \& L. C. Torgan, 2016. Falcula hyalina (Fragilariaceae, Bacillariophyta) from a coastal lagoon, Southern Brazil: an additional approach on its morphology. Phytotaxa 243(2): 185-189.

Duong, T. T., S. Morin, O. Herlory, A. Feurtet-Mazel, M. Coste \& A. Boudou, 2008. Seasonal effects of cadmium accumulation in periphytic diatom communities of freshwater biofilms. Aquatic Toxicology 90(1): 19-28.

Duong, T. T., S. Morin, M. Coste, O. Herlory, A. Feurtet-Mazel \& A. Boudou, 2010. Experimental toxicity and bioaccumulation of cadmium in freshwater periphytic diatoms in relation with biofilm maturity. Science of the Total Environment 408(3): 552-562.

Dziengo-Czaja, M., J. A. Matuszak, 2008. Teratological forms of diatoms (Bacillariophyceae) as indicators of water pollution in the western part of Puck Bay (southern Baltic Sea). Oceanological and Hydrobiological Studies 37(2): 119-132.

Ector, L., 2011. 1st European Workshop on Diatom Taxonomy (1st EWDT). Algological Studies 136-137: 1-4. 
Edlund, M. B. \& E. F. Stoermer, 1991. Sexual reproduction in Stephanodiscus niagarae (Bacillariophyta). Journal of Phycology 27(6): 780-793.

Esquius, K. S., S. M. Altamirano \& A. H. Escalante, 2012. Abnormal forms of Cocconeis placentula (Ehrenberg) in a eutrophic shallow lake (BS. AS. Province, Argentina). In Dos Santos Afonso, M. \& R. M. T. Sanchez (eds), Ciencia y tecnologia ambiental: un enfoque integrador [Environmental Science an Technology: An Integrative Approach; Conference Proceedings] Argentina y Ambiente May 2012, Mar De Plata, Argentina. Asociación Argentina para el Progreso de las Ciencias, Buenos Aires: 250-255.

Estes, A. \& R. R. Dute, 1994. Valve abnormalities in diatom clones maintained in long-term culture. Diatom Research 9(2): 249-258.

Falasco, E., F. Bona, G. Badino, L. Hoffmann \& L. Ector, 2009a. Diatom teratological forms and environmental alterations: a review. Hydrobiologia 623: 1-35.

Falasco, E., F. Bona, M. Ginepro, D. Hlúbiková, L. Hoffmann \& L. Ector, 2009b. Morphological abnormalities of diatom silica walls in relation to heavy metal contamination and artificial growth conditions. Water SA 35(5): 595-606.

Falasco, E., L. Mobili, A. M. Risso \& F. Bona, 2012. Considerazioni sull'applicazione dell'indice diatomico ICMi (Intercalibration Common Metric index) nell'Italia nordoccidentale. Biologia Ambientale 26(1): 21-28.

Falasco, E., F. Bona, M. Isaia, E. Piano, C. E. Wetzel, L. Hoffmann \& L. Ector, 2015. Nupela troglophila sp. nov., an aerophilous diatom (Bacillariophyta) from the Bossea Cave (NW Italy), with notes on its ecology. Fottea 15(1): $1-9$.

Falasco, E., E. Piano, A. Doretto, S. Fenoglio \& F. Bona, 2018a. Resilience of benthic diatom communities in Mediterranean streams: role of endangered species. Marine and Freshwater Research 70(2): 212-224.

Falasco, E., E. Piano, A. Doretto, S. Fenoglio \& F. Bona, 2018b. Lentification in Alpine rivers: patterns of diatom assemblages and functional traits. Aquatic Sciences 80: 36.

Fernández, M. R., G. Martín, J. Corzo, A. de la Linde, E. García, M. López \& M. Sousa, 2018. Design and testing of a new diatom-based index for heavy metal pollution. Archives of Environmental Contamination and Toxicology 74(1): 170-192.

Ferreira da Silva, E., S. F. P. Almeida, M. L. Nunes, A. T. Luís, F. Borg, M. Hedlund, C. M. de Sá, C. Patinha \& P. Teixeira, 2009. Heavy metal pollution downstream the abandoned Coval da Mó Mine (Portugal) and associated effects on epilithic diatom communities. Science of the Total Environment 407(21): 5620-5636.

Figueira, E., R. Freitas, H. Guasch \& S. F. P. Almeida, 2014. Efficiency of cadmium chelation by phytochelatins in Nitzschia palea (Kützing) W. Smith. Ecotoxicology 23: 285-292.

Fisher, N. S. \& D. Frood, 1980. Heavy metals and marine diatoms: influence of dissolved organic compounds on toxicity and selection for metal tolerance among four species. Marine Biology 59: 85-93.

Fisher, N. S., G. J. Jones \& D. M. Nelson, 1981. Effects of copper and zinc on growth, morphology, and metabolism of Asterionella japonica (Cleve). Journal of Experimental Marine Biology and Ecology 51: 37-56.
Fontana, L., A. L. S. Albuquerque, M. Brenner, D. M. Bonotto, T. P. P. Sabaris, M. A. F. Pires, M. E. B. Cotrim \& D. C. Bicudo, 2014. The eutrophication history of a tropical water supply reservoir in Brazil. Journal of Paleolimnology 51(1): 29-43.

Franz, S., R. Altenburger, H. Heilmeier \& M. Schmitt-Jansen, 2008. What contributes to the sensitivity of microalgae to triclosan? Aquatic Toxicology 90(2): 102-108.

Furey, P. C., R. L. Lowe \& J. R. Johansen, 2009. Teratology in Eunotia taxa in the Great Smoky Mountains National Park and description of Eunotia macroglossa sp. nov. Diatom Research 24(2): 273-290.

Gautam, S., L. K. Pandey, V. Vinayak \& A. Arya, 2017. Morphological and physiological alterations in the diatom Gomphonema pseudoaugur due to heavy metal stress. Ecological Indicators 72: 67-76.

Geitler, L., 1977. Entwicklungsgeschichtliche Eigentumlichkeiten einiger Achnanthes-Arten (Diatomeae). Plant Systematics and Evolution 126: 377-392.

Gold, C., 2002. Etude des effets de la pollution métallique $(\mathrm{Cd} /$ $\mathrm{Zn)} \mathrm{sur} \mathrm{la} \mathrm{structure} \mathrm{des} \mathrm{communautés} \mathrm{de} \mathrm{diatomées} \mathrm{péri-}$ phytiques des cours d'eau. Approches expérimentales in situ et en laboratoire. Thèse. Ecole Doctorale "Sciences du vivant, Géosciences et Sciences de l'Environnement", Spécialité Ecotoxicologie, Université Bordeaux I. 175 pp. + Annexes.

Gold, C., A. Feurtet-Mazel, M. Coste \& A. Boudou, 2003a. Impacts of $\mathrm{Cd}$ and $\mathrm{Zn}$ on the development of periphytic diatom communities in artificial streams located along a river pollution gradient. Archives of Environmental Contamination and Toxicology 44: 189-197.

Gold, C., A. Feurtet-Mazel, M. Coste \& A. Boudou, 2003b. Effects of cadmium stress on periphytic diatom communities in indoor artificial streams. Freshwater Biology 48: 316-328.

Gómez, N. \& M. Licursi, 2003. Abnormal forms in Pinnularia gibba (Bacillariophyceae) in a polluted lowland stream from Argentina. Nova Hedwigia 77(3-4): 389-398.

Gómez, N., M. V. Sierra, A. Cortelezzi \& A. Rodrigues Capítulo, 2008. Effects of discharges from the textile industry on the biotic integrity of benthic assemblages. Ecotoxicology and Environmental Safety 69: 472-479.

Gonçalves, S., S. F. P. Almeida, E. Figueira \& M. Kahlert, 2019. Valve teratologies and $\mathrm{Chl} c$ in the freshwater diatom $\mathrm{Ta}$ bellaria flocculosa as biomarkers for metal contamination. Ecological Indicators 101: 476-485.

Gordon, R. \& R. W. Drum, 1994. The chemical basis of diatom morphogenesis. International Review of Cytology 150: 243-372.

Grabowska, M., F. Hindák \& A. Hindáková, 2014. Phototrophic microflora of dystrophic Lake Sęczek, Masuria, Poland. Oceanological and Hydrobiological Studies 43(4): 337-345.

Granetti, B., 1968a. Alcune forme teratologiche comparse in colture di Navicula minima Grun. e Navicula seminulum Grun. Giornale Botanico Italiano 102(6): 469-484.

Granetti, B., 1968b. Comportamento di un carattere teratologico comparso in Navicula minima Grun. Giornale Botanico Italiano 102(6): 507-513. 
Granetti, B., 1978. Struttura di alcune valve teratologiche di Navicula gallica (W. Smith) Van Heurck. Giornale Botanico Italiano 112(1-2): 1-12.

Greenaway, C. M., A. M. Paterson, W. Keller \& J. P. Smol, 2012. Dramatic diatom species assemblage responses in lakes recovering from acidification and metal contamination near Wawa, Ontario, Canada: a paleolimnological perspective. Canadian Journal of Fisheries and Aquatic Sciences 69(4): 656-669.

Guasch, H., X. G. Acosta, G. Urrea \& L. Bañeras, 2012. Changes in the microbial communities along the environmental gradient created by a small Fe spring. Freshwater Science 31(2): 599-609.

Håkansson, H. \& H. Kling, 1990. The current status of some very small freshwater diatoms of the genera Stephanodiscus and Cyclostephanos. Diatom Research 5(2): 273-287.

Håkansson, H. \& A. Korhola, 1998. Phenotypic plasticity in the diatom Cyclotella meneghiniana or a new species? Nova Hedwigia 66(1-2): 187-196.

Harper, M. A., D. G. Mann \& J. E. Patterson, 2009. Two unusual diatoms from New Zealand: Tabularia variostriata a new species and Eunophora berggrenii. Diatom Research 24(2): 291-306.

Hazelaar, S., H. J. van der Strate, W. W. C. Gieskes \& E. $\mathrm{G}$. Vrieling, 2005. Monitoring rapid valve formation in the pennate diatom Navicula salinarum (Bacillariophyceae). Journal of Phycology 41(2): 354-358.

Hildebrand, M., S. J. L. Lerch \& R. P. Shrestha, 2018. Understanding diatom cell wall silicification - moving forward. Frontiers in Marine Science 5: 125.

Hlúbiková, D., L. Ector \& L. Hoffmann, 2011. Examination of the type material of some diatom species related to Achnanthidium minutissimum (Kütz.) Czarn. (Bacillariophyceae). Algological Studies 136/137: 19-43.

Hodgson, D. A., W. Vyverman, A. Chepstow-Lusty \& P. A. Tyler, 2000. From rainforest to wasteland in 100 years: The limnological legacy of the Queenstown mines, Western Tasmania. Archiv für Hydrobiologie 149(1): 153-176.

Holmes, M. \& J. C. Taylor, 2015. Diatoms as water quality indicators in the upper reaches of the Great Fish River, Eastern Cape, South Africa. African Journal of Aquatic Science 40(4): 321-337.

Hostetter, H. P. \& K. D. Rutherford, 1976. Polymorphism of the diatom Pinnularia brebissonii in culture and a field collection. Journal of Phycology 12(2): 140-146.

Hustedt, F., 1927. Die Kieselalgen Deutschlands, Österreichs und der Schweiz unter Berücksichtigung der übrigen Länder Europas sowie der angrenzenden Meeresgebiete. Bd. VII: Teil 1: Liefrung 1. In Anon. (eds), Rabenhorst's Kryptogamen Flora von Deutschland, Österreich und der Schweiz. Akademische Verlagsgesellschaft m.b.h., Leipzig: $1-272$

Hustedt, F., 1950. Die Diatomeenflora norddeutscher Seen mit besonderer Berücksichtigung des holsteinischen Seengebiets. V.-VII. Seen in Mecklenburg, Lauenburg und Nordostdeutschland. Archiv für Hydrobiologie 43: 329-458.

Ivorra, N., S. Bremer, H. Guasch, M. H. S. Kraak \& W. Admiraal, 2000. Differences in the sensitivity of benthic microalgae to $\mathrm{Zn}$ and $\mathrm{Cd}$ regarding biofilm development and exposure history. Environmental Toxicology and Chemistry 19(5): 1332-1339.
Ivorra, N., J. Hettelaar, M. H. S. Kraak, S. Sabater \& W. Admiraal, 2002. Responses of biofilms to combined nutrient and metal exposure. Environmental Toxicology and Chemistry 21(3): 626-632.

Jahn, R. \& W.-H. Kusber, 2004. Algae of the Ehrenberg collection - 1. Typification of 32 names of diatom taxa described by C. G. Ehrenberg. Willdenowia 34(2): 577-595.

Jahn, R., N. Abarca, B. Gemeinholzer, D. Mora, O. Skibbe, M. Kulikovskiy, E. Gusev, W.-H. Kusber \& J. Zimmermann, 2017. Planothidium lanceolatum and Planothidium frequentissimum reinvestigated with molecular methods and morphology: four new species and the taxonomic importance of the sinus and cavum. Diatom Research 32(1): 75-107.

Jia, K., C. Sun, Y. Wang, X. Li, W. Mu \& Y. Fan, 2019. Effect of $\mathrm{TiO}_{2}$ nanoparticles and multiwall carbon nanotubes on the freshwater diatom Nitzschia frustulum: evaluation of growth, cellular components and morphology. Chemistry and Ecology 35(1): 69-85.

Jones, J. I., J. F. Murphy, A. L. Collins, K. L. Spencer, P. S. Rainbow, A. Arnold, J. L. Pretty, A. M. L. Moorhouse, V. Aguilera, P. Edwards, F. Parsonage, H. Potter \& P. Whitehouse, 2018. The impact of metal-rich sediments derived from mining on freshwater stream life. In: de Voogt, P. (ed) Reviews of Environmental Contamination and Toxicology, vol 248. Springer, Cham, pp 111-189.

Jung, S. W. \& J. S. Park, 2019. Two fouling Olifantiella (Bacillariophyceae) species from the northwest temperate Pacific coast. Diatom Research 34(3):165-180.

Kennedy, B. \& N. Allott, 2017. A review of the genus Brachysira in Ireland with the description of Brachysira praegeri and Brachysira conamarae, new raphid diatoms (Bacillariophyceae) from high status waterbodies. Phytotaxa 326(1): 1-27.

Kim, Y. S., J. S. Choi, J. H. Kim, S. C. Kim, J. W. Park \& H. S. Kim, 2008. The effects of effluent from a closed mine and treated sewage on epilithic diatom communities in a Korean stream. Nova Hedwigia 86(3-4): 507-524.

Kim Tiam, S., I. Lavoie, C. Doose, P. B. Hamilton \& C. Fortin, 2018. Morphological, physiological and molecular responses of Nitzschia palea under cadmium stress. Ecotoxicology 27(6): 675-688.

Kim Tiam, S., I. Lavoie, F. Liu, P. B. Hamilton \& C. Fortin, 2019. Diatom deformities and tolerance to cadmium contamination in four species. Environments 6(9): 102.

Kiran Marella, T., A. Saxena \& A. Tiwari, 2020. Diatom mediated heavy metal remediation: a review. Bioresource Technology 305: 123068.

Kociolek, J. P. \& E. W. Thomas, 2010. Taxonomy and ultrastructure of five naviculoid diatoms (class Bacillariophyceae) from the Rocky Mountains of Colorado (USA), with the description of a new genus and four new species. Nova Hedwigia 90(1-2): 195-214.

Lai, G. G., B. M. Padedda, C. E. Wetzel, M. Cantonati, N. Sechi, A. Lugliè \& L. Ector, 2019. Diatom assemblages from different substrates of the Casteldoria thermo-mineral spring (Northern Sardinia, Italy). Botany Letters 166(1): $14-31$.

Lainé, M., S. Morin \& J. Tison-Rosebery, 2014. A multicompartment approach - diatoms, macrophytes, benthic 
macroinvertebrates and fish - to assess the impact of toxic industrial releases on a small French river. PLoS ONE 9(7): e102358.

Laird, K. R., B. Das \& B. F. Cumming, 2015. Siliceous microfossil changes in impact and reference lakes in the uranium mining region of the Athabasca Basin in northern Saskatchewan. Journal of Paleolimnology 53(4): 367-383.

Larras, F., A. Bouchez, F. Rimet \& B. Montuelle, 2012. Using bioassays and species sensitivity distributions to assess herbicide toxicity towards benthic diatoms. PLoS ONE 7(8): e44458.

Lavoie, I., M. Lavoie \& C. Fortin, 2012. A mine of information: benthic algal communities as biomonitors of metal contamination from abandoned tailings. Science of the Total Environment 425: 231-241.

Lavoie, I., P. B. Hamilton, S. Morin, S. Kim Tiam, M. Kahlert, S. Gonçalves, E. Falasco, C. Fortin, B. Gontero, D. Heudre, M. Kojadinovic-Sirinelli, K. Manoylov, L. K. Pandey \& J. C. Taylor, 2017. Diatom teratologies as biomarkers of contamination: are all deformities ecologically meaningful? Ecological Indicators 82: 539-550.

Lavoie, I., S. Morin, V. Laderriere \& C. Fortin, 2018. Freshwater diatoms as indicators of combined long-term mining and urban stressors in Junction Creek (Ontario, Canada). Environments 5(2): 30.

Lavoie, I., S. Morin, V. Laderriere, L.-E. Paris \& C. Fortin, 2019. Assessment of diatom assemblages in close proximity to mining activities in Nunavik, Northern Quebec (Canada). Environments 6: 74.

Lee, J. J. \& X. Xenophontes, 1989. The unusual life cycle of Navicula muscatinei. Diatom Research 4(1): 69-77.

Leguay, S., I. Lavoie, J. L. Levy \& C. Fortin, 2016. Using biofilms for monitoring metal contamination in lotic ecosystems: the protective effects of hardness and $\mathrm{pH}$ on metal bioaccumulation. Environmental Toxicology and Chemistry 35(6): 1489-1501.

León, P. F., P. F. Vásquez, L. S. Quispe \& E. O. Passuni, 2018. Diatomeas teratológicas como organismos bioindicadores de la calidad del agua del río Tingo, Hualgayoc, Cajamarca [Teratological diatoms as bioindicating organisms of the quality of the water of the Tingo River, Hualgayoc, Cajamarca]. Ciencia \& Desarrollo 17, 22(1): 26-33.

Licursi, M. \& N. Gómez, 2013. Short-term toxicity of hexavalent-chromium to epipsammic diatoms of a microtidal estuary (Río de la Plata): responses from the individual cell to the community structure. Aquatic Toxicology 134-135: $82-91$.

Luís, A. T., P. Teixeira, S. F. P. Almeida, J. X. Matos \& E. Ferreira da Silva, 2011. Environmental impact of mining activities in the Lousal area (Portugal): chemical and diatom characterization of metal-contaminated stream sediments and surface water of Corona stream. Science of the Total Environment 409: 4312-4325.

Luís, A. T., A. C. Alexander, S. F. P. Almeida, E. Ferreira da Silva \& J. M. Culp, 2013. Benthic diatom communities in streams from zinc mining areas in continental (Canada) and Mediterranean climates (Portugal). Water Quality Research Journal of Canada 48(2): 180-191.

Luís, A. T., N. Durães, S. F. P. Almeida \& E. Ferreira da Silva, 2016. Integrating geochemical (surface waters, stream sediments) and biological (diatoms) approaches to assess
AMD environmental impact in a pyritic mining area: Aljustrel (Alentejo, Portugal). Journal of Environmental Sciences 42: 215-226.

Luís, A. T., J. A. Grande, N. Durães, J. M. Dávila, M. Santisteban, S. F. P. Almeida, A. M. Sarmiento, M. L. de la Torre, J. C. Fortes \& E. Ferreira da Silva, 2019. Biogeochemical characterization of surface waters in the Aljustrel mining area (South Portugal). Environmental Geochemistry and Health 41(5): 1909-1921.

Majewska, R., A. Zgrundo, P. Lemke \& M. De Stefano, 2012. Benthic diatoms of the Vistula River estuary (Northern Poland): seasonality, substrata preferences, and the influence of water chemistry. Phycological Research 60(1): $1-19$.

Masmoudi, S., N. Nguyen-Deroche, A. Caruso, H. Ayadi, A. Morant-Manceau, G. Tremblin, M. Bertrand \& B. Schoefs, 2013. Cadmium, copper, sodium and zinc effects on diatoms: from heaven to hell - a review. Cryptogamie, Algologie 34(2): 185-225.

McFarland, B. H., B. H. Hill \& W. T. Willingham, 1997. Abnormal Fragilaria spp. (Bacillariophyceae) in streams impacted by mine drainage. Journal of Freshwater Ecology 12(1): 141-149.

McMillan, M. \& J. R. Johansen, 1988. Changes in valve morphology of Thalassiosira decipiens (Bacillariophyceae) cultured in media of four different salinities. British Phycological Journal 23(4): 307-316.

Medvedeva, L. A., S. S. Barinova \& A. A. Semenchenko, 2012. Use of algae for monitoring rivers in the monsoon climate areas (Russian part of Asian Pacific Region). International Journal of Environment and Resource 1(1): 39-44.

Miao, A.-J., K. A. Schwehr, C. Xu, S.-J. Zhang, Z. Luo, A. Quigg \& P. H. Santschi, 2009. The algal toxicity of silver engineered nanoparticles and detoxification by exopolymeric substances. Environmental Pollution 157(11): 3034-3041.

Millan, F., C. Izere, V. Breton, O. Voldoire, D. G. Biron, C. E. Wetzel, D. Miallier, E. Allain, L. Ector \& A. Beauger, 2020. The effect of natural radioactivity on diatom communities in mineral springs. Botany Letters 167(1): 95-113.

Mitlehner, A. G., 2019. Species of the diatom taxa Aulacodiscus and Trinacria with biostratigraphic utility in Palaeogene and Neogene North Sea sediments. Journal of Micropalaeontology 38: 67-81.

Moos, M. T. \& B. K. Ginn, 2016. Developing a lake management strategy by dovetailing lake monitoring with paleolimnological techniques: a case study from a Kettle Lake on the Oak Ridges Moraine (Ontario, Canada). Lake and Reservoir Management 32(3): 234-245.

Mora, D., J. Carmona, \& E. A. Cantoral-Uriza, 2015. Diatomeas epilíticas de la cuenca alta del río Laja, Guanajuato, México [Epilithic diatoms in the Upper Laja River Basin, Guanajuato, Mexico]. Revista Mexicana de Biodiversidad 86(4): 1024-1040.

Morales, E. A., S. F. Rivera, C. E. Wetzel, M. H. Novais, P. B. Hamilton, L. Hoffmann \& L. Ector, 2014. New epiphytic araphid diatoms in the genus Ulnaria (Bacillariophyta) from Lake Titicaca, Bolivia. Diatom Research 29(1): 41-54. 
Morel, N. M. L., J. G. Rueter \& F. M. M. Morel, 1978. Copper toxicity to Skeletonema costatum (Bacillariophyceae). Journal of Phycology 14(1): 43-48.

Morin, S. \& M. Coste, 2006. Metal-induced shifts in the morphology of diatoms from the Riou Mort and Riou Viou streams (South West France). In Ács, É., K. T. Kiss, J. Padisák \& K. É. Szabó (eds), 6th International Symposium on Use of Algae for Monitoring Rivers, Hungary, Balatonfüred, 12-16 September 2006. Hungarian Algological Society, Göd: 97-106.

Morin, S., M. Vivas-Nogues, T. T. Duong, A. Boudou, M. Coste \& F. Delmas, 2007. Dynamics of benthic diatom colonization in a cadmium/zinc-polluted river (Riou-Mort, France). Fundamental and Applied Limnology/Archiv für Hydrobiologie 168(2): 179-187.

Morin, S., M. Coste \& P. B. Hamilton, 2008a. Scanning electron microscopy observations of deformities in small pennate diatoms exposed to high cadmium concentrations. Journal of Phycology 44(6): 1512-1518.

Morin, S., T. T. Duong, A. Dabrin, A. Coynel, O. Herlory, M. Baudrimont, F. Delmas, G. Durrieu, J. Schäfer, P. Winterton, G. Blanc \& M. Coste, 2008b. Long-term survey of heavy-metal pollution, biofilm contamination and diatom community structure in the Riou Mort watershed, SouthWest France. Environmental Pollution 151(3): 532-542.

Morin, S., T. T. Duong, O. Herlory, A. Feurtet-Mazel \& M. Coste, 2008c. Cadmium toxicity and bioaccumulation in freshwater biofilms. Archives of Environmental Contamination and Toxicology 54(2): 173-186.

Morin, S., A. Cordonier, I. Lavoie, A. Arini, S. Blanco, T. T. Duong, E. Tornés, B. Bonet, N. Corcoll, L. Faggiano, M. Laviale, F. Pérès, E. Becares, M. Coste, A. Feurtet-Mazel, C. Fortin, H. Guasch \& S. Sabater, 2012a. Consistency in diatom response to metal-contaminated environments. In Guasch, H., A. Ginebreda \& A. Geiszinger (eds), Emerging and Priority Pollutants in Rivers, Bringing Science into River Management Plans, The Handbook of Environmental Chemistry, vol 19. Springer, Berlin, pp 117-146.

Morin, S., A.-S. Lambert, J. Artigas, M. Coquery \& S. Pesce, 2012b. Diatom immigration drives biofilm recovery after chronic copper exposure. Freshwater Biology 57(8): 1658-1666.

Morin, S., N. Corcoll, B. Bonet, A. Tlili \& H. Guasch, 2014. Diatom responses to zinc contamination along a Mediterranean river. Plant Ecology and Evolution 147(3): 325-332.

Morin, S., B. Bonet, N. Corcoll, H. Guasch, M. Bottin, \& M. Coste, 2015. Cumulative stressors trigger increased vulnerability of diatom communities to additional disturbances. Microbial Ecology 70: 585-595.

Mu, W., K. Jia, Y. Liu, X. Pan \& Y. Fan, 2017. Response of the freshwater diatom Halamphora veneta (Kützing) Levkov to copper and mercury and its potential for bioassessment of heavy metal toxicity in aquatic habitats. Environmental Science and Pollution Research 24: 26375-26386.

Mu, W., Y. Chen, Y. Liu, X. Pan \& Y. Fan, 2018. Toxicological effects of cadmium and lead on two freshwater diatoms. Environmental Toxicology and Pharmacology 59: 152-162.
Murakami, T. \& M. Kasuya, 1993. Teratological variations of Gomphonema parvulum Kützing in a heavily polluted drainage channel. Diatom 8: 7-10.

Naveed, S., C. Li, X. Lu, S. Chen, B. Yin, C. Zhang \& Y. Ge, 2019. Microalgal extracellular polymeric substances and their interactions with metal(loid)s: a review. Critical Reviews in Environmental Science and Technology 49(19): 1769-1802.

Nicolosi Gelis, M. M., J. Cochero, J. Donadelli \& N. Gómez, 2020. Exploring the use of nuclear alterations, motility and ecological guilds in epipelic diatoms as biomonitoring tools for water quality improvement in urban impacted lowland streams. Ecological Indicators 110: 105951.

Novais, M. H., I. Jüttner, B. Van de Vijver, M. M. Morais, L. Hoffmann \& L. Ector, 2015. Morphological variability within the Achnanthidium minutissimum species complex (Bacillariophyta): comparison between the type material of Achnanthes minutissima and related taxa, and new freshwater Achnanthidium species from Portugal. Phytotaxa 224(2): 101-139.

Novis, P. M., J. Braidwood \& C. Kilroy, 2012. Small diatoms (Bacillariophyta) in cultures from the Styx River, New Zealand, including descriptions of three new species. Phytotaxa 64: 11-45.

Nunes, M. L., E. Ferreira da Silva \& S. F. P. Almeida, 2003. Assessment of water quality in the Caima and Mau River Basins (Portugal) using geochemical and biological indices. Water, Air, and Soil Pollution 149: 227-250.

Olenici, A., S. Blanco, M. Borrego-Ramos, L. Momeu \& C. Baciu, 2017. Exploring the effects of acid mine drainage on diatom teratology using geometric morphometry. Ecotoxicology 26(8): 1018-1030.

Olenici, A., S. Blanco, M. Borrego-Ramos, F. Jiménez-Gómez, F. Guerrero, L. Momeu \& C. Baciu, 2018. Metal-induced abnormalities in diatom girdle bands. bioRxiv, 501619 .

Olenici, A., S. Blanco, M. Borrego-Ramos, F. Jiménez-Gómez, F. Guerrero, L. Momeu \& C. Baciu, 2019. A new diatom teratology driven by metal pollution in a temperate river (Roşia Montană, Romania). Annali di Botanica (Roma) 9: 113-118.

Olenici, A., C. Baciu, S. Blanco \& S. Morin, 2020. Naturally and environmentally driven variations in diatom morphology: implications for diatom-based assessment of water quality. In Cristóbal, G., S. Blanco \& G. Bueno (eds), Modern Trends in Diatom Identification. Fundamentals and Applications. Developments in Applied Phycology 10. Springer, Cham, pp 39-50.

Oreshkina, T. V., E. A. Lygina, O. A. Vozhzhova \& A. V. Ivanov, 2013. Diatoms and silicoflagellates of the Upper Cretaceous from Saratov Region: biostratigraphy and sedimentation settings. Stratigraphy and Geological Correlation 21(2): 222-236.

Pandey, L. K., 2020. In situ assessment of metal toxicity in riverine periphytic algae as a tool for biomonitoring of fluvial ecosystems. Environmental Technology and Innovation 18: 100675.

Pandey, L. K. \& E. A. Bergey, 2016. Exploring the status of motility, lipid bodies, deformities and size reduction in periphytic diatom community from chronically metal $(\mathrm{Cu}$, $\mathrm{Zn}$ ) polluted waterbodies as a biomonitoring tool. Science of the Total Environment 550: 372-381. 
Pandey, L. K. \& E. A. Bergey, 2018. Metal toxicity and recovery response of riverine periphytic algae. Science of the Total Environment 642: 1020-1031.

Pandey, L. K., D. Kumar, A. Yadav, J. Rai \& J. P. Gaur, 2014. Morphological abnormalities in periphytic diatoms as a tool for biomonitoring of heavy metal pollution in a river. Ecological Indicators 36: 272-279.

Pandey, L. K., T. Han \& J. P. Gaur, 2015. Response of a phytoplanktonic assemblage to copper and zinc enrichment in microcosm. Ecotoxicology 24(3): 573-582.

Pandey, L. K., E. A. Bergey, J. Lyu, J. Park, S. Choi, H. Lee, S. Depuydt, Y.-T. Oh, S.-M. Lee \& T. Han, 2017. The use of diatoms in ecotoxicology and bioassessment: insights, advances and challenges. Water Research 118: 39-58.

Pandey, L. K., I. Lavoie, S. Morin, J. Park, J. Lyu, S. Choi, H. Lee \& T. Han, 2018a. River water quality assessment based on a multi-descriptor approach including chemistry, diatom assemblage structure, and non-taxonomical diatom metrics. Ecological Indicators 84: 140-151.

Pandey, L. K., Y. C. Sharma, J. Park, S. Choi, H. Lee, J. Lyu \& T. Han, 2018b. Evaluating features of periphytic diatom communities as biomonitoring tools in fresh, brackish and marine waters. Aquatic Toxicology 194: 67-77.

Pandey, L. K., I. Lavoie, S. Morin, S. Depuydt, J. Lyu, H. Lee, J. Jung, D.-H. Yeom, T. Han \& J. Park, 2019. Towards a multi-bioassay-based index for toxicity assessment of fluvial waters. Environmental Monitoring and Assessment 191(2): 112

Park, J., H. Lee, S. Depuydt, T. Han \& L. K. Pandey, 2020. Assessment of five live-cell characteristics in periphytic diatoms as a measure of copper stress. Journal of Hazardous Materials 400: 123113.

Pennesi, C., R. Majewska, F. A. S. Sterrenburg, C. Totti \& M. De Stefano, 2018. Taxonomic revision and morphological cladistics analysis of the diatom genus Anorthoneis (Cocconeidaceae), with description of Anorthoneis arthus-bertrandii sp. nov. Phytotaxa 336(3): 201-238.

Peres-Weerts, F., 2000. Mise en évidence des effets toxiques des métaux lourds sur les diatomées par l'étude des formes tératogènes. Agence de l'Eau Artois Picardie, Douai: 24 pp.

Pham, T.-L., 2019. Effect of silver nanoparticles on tropical freshwater and marine microalgae. Journal of Chemistry 2019: 9658386

Podda, F., D. Medas, G. De Giudici, P. Ryszka, K. Wolowski \& K. Turnau, 2014. Zn biomineralization processes and microbial biofilm in a metal-rich stream (Naracauli, Sardinia). Environmental Science and Pollution Research 21: 6793-6808, 6809-6811 (Erratum).

Potapova, M. \& P. B. Hamilton, 2007. Morphological and ecological variation within the Achnanthidium minutissimum (Bacillariophyceae) species complex. Journal of Phycology 43(3): 561-575.

Reichardt, E., 2015. Gomphonema gracile Ehrenberg sensu stricto et sensu auct. (Bacillariophyceae): a taxonomic revision. Nova Hedwigia 101(3-4): 367-393.

Renzi, M., L. Roselli, A. Giovani, S. E. Focardi \& A. Basset, 2014. Early warning tools for ecotoxicity assessment based on Phaeodactylum tricornutum. Ecotoxicology 23: 1055-1072.
Rijstenbil, J. W., J. W. M. Derkesen, L. J. A. Gerringa, T. C. W. Poortvliet, A. Sandee, M. van den Berg, J. van Drie \& J. A. Wijnholds, 1994. Oxidative stress induced by copper: defense and damage in the marine planktonic diatom Ditylum brightwellii, grown in continuous cultures with high and low zinc levels. Marine Biology 119: 583-590.

Rimet, F. \& A. Bouchez, 2012. Life-forms, cell-sizes and ecological guilds of diatoms in European rivers. Knowledge and Management of Aquatic Ecosystems 406: 01.

Rimet, F., L. Ector, A. Dohet \& H. M. Cauchie, 2004. Impacts of fluoranthene on diatom assemblages and frustule morphology in indoor microcosms. Vie Milieu 54(2-3): 145-156.

Rogelja, M., T. Cibic, C. Pennesi \& C. De Vittor, 2016. Microphytobenthic community composition and primary production at gas and thermal vents in the Aeolian Islands (Tyrrhenian Sea, Italy). Marine Environmental Research 118: $31-44$.

Round, F. E., 1992. A re-investigation of some fragilarioid diatoms in the Provasoli/Guillard culture collection. Diatom Research 7(2): 303-311.

Round, F. E., 1993. A Synedra (Bacillariophyta) clone after several years in culture. Nova Hedwigia, Beiheft 106: 353-359.

Ruggiu, D., A. Luglié, A. Cattaneo \& P. Panzani, 1998. Paleoecological evidence for diatom response to metal pollution in Lake Orta (N. Italy). Journal of Paleolimnology 20: 333-345.

Saboski, E. M., 1977. Effects of mercury and tin on frustular ultrastructure of the marine diatom Nitzschia liebethrutti. Water, Air, and Soil Pollution 8: 461-466.

Salusso, M. M. \& L. B. Moraña, 2015. Estructura y composición del fitoplancton de Mina Pirquitas, Jujuy, Argentina [Structure and composition of phytoplankton from Mina Pirquitas, Jujuy, Argentina]. Revista Mexicana de Biodiversidad 86(3): 711-718.

Santos, J., S. F. P. Almeida \& E. Figueira, 2013. Cadmium chelation by frustulins: a novel metal tolerance mechanism in Nitzschia palea (Kützing) W. Smith. Ecotoxicology 22(1): 166-173.

Santos, J., S. F P. Almeida, R. Freitas, C. Velez, S. Esteves \& E. Figueira, 2016. Intraspecific differences in cadmium tolerance of Nitzschia palea (Kützing) W. Smith: a biochemical approach. Ecotoxicology 25(7): 1305-1317.

Schmid, A.-M. M., 1979. Influence of environmental factors on the development of the valve in diatoms. Protoplasma 99: 99-115.

Schmid, A.-M. M., 1980. Valve morphogenesis in diatoms: a pattern-related filamentous system in pennates and the effect of APM, colchicine and osmotic pressure. Nova Hedwigia 33: 811-847.

Schmid, A.-M. M., 1984. Wall morphogenesis in Thalassiosira eccentrica: comparison of auxospore formation and the effect of MT-inhibitors. In Mann, D. G. (ed.), Proceedings of the Seventh International Diatom Symposium, Philadelphia, August 22-27, Vol. 982. Otto Koeltz, Koenigstein: 47-70.

Schmitt-Jansen, M. \& R. Altenburger, 2005. Toxic effects of isoproturon on periphyton communities - a microcosm study. Estuarine, Coastal and Shelf Science 62: 539-545. 
Schröfel, A., G. Kratošová, M. Bohunická, E. Dobročka \& I. Vávra, 2011. Biosynthesis of gold nanoparticles using diatoms - silica-gold and EPS-gold bionanocomposite formation. Journal of Nanoparticle Research 13: 3207-3216.

Sienkiewicz, E. \& M. Gąsiorowski, 2016. The evolution of a mining lake - from acidity to natural neutralization. Science of the Total Environment 557-558: 343-354.

Sienkiewicz, E. \& M. Gąsiorowski, 2017. The diatom-inferred $\mathrm{pH}$ reconstructions for a naturally neutralized pit lake in south-west Poland using the Mining and the Combined $\mathrm{pH}$ training sets. Science of the Total Environment 605-606: $75-87$.

Sienkiewicz, E. \& M. Gạsiorowski, 2019. Natural evolution of artificial lakes formed in lignite excavations based on diatom, geochemical and isotopic data. Journal of Paleolimnology 62: 1-13.

Sierra, M. V. \& N. Gómez, 2010. Assessing the disturbance caused by an industrial discharge using field transfer of epipelic biofilm. Science of the Total Environment 408(13): 2696-2705.

Simić, S. B., A. S. Petrović, N. B. Đorđević, B. M. Vasiljević, N. M. Radojković, A. B. Mitrović \& M. G. Janković, 2018. Indicative ecological status assessment of the Despotovica River. Kragujevac Journal of Science 40: 227-242.

Sivarajah, B., J. B. Korosi, J. M. Blais \& J. P. Smol, 2019. Multiple environmental variables influence diatom assemblages across an arsenic gradient in 33 sub-Arctic lakes near abandoned gold mines. Hydrobiologia 841(1): 133-151.

Śliwińska-Wilczewska, S., Z. Sylwestrzak, J. Maculewicz, A. Zgrundo, F. Pniewski \& A. Latała, 2016. The effects of allelochemicals and selected anthropogenic substances on the diatom Bacillaria paxillifera. Edukacja Biologiczna I Środowiskowa 1: 21-27.

Smeti, E., E. Kalogianni, I. Karaouzas, S. Laschou, E. Tornés, N. De Castro-Català, E. Anastasopoulou, M. Koutsodimou, A. Andriopoulou, L. Vardakas, I. Muñoz, S. Sabater \& N. Th. Skoulikidis, 2019. Effects of olive mill wastewater discharge on benthic biota in Mediterranean streams. Environmental Pollution 254: 113057.

Smith, T. \& K. Manoylov, 2007. Diatom deformities from an acid mine drainage site at Friendship Hills National Historical Site, Pennsylvania. Journal of Freshwater Ecology 22(3): 521-527.

Soylu, E. N., 2015. Flood pulse influence on phytoplankton community of the Aksu Stream, Giresun, Turkey. Journal of Environmental Biology 36(1): 185-190.

Stachura-Suchoples, K., N. Enke, C. Schlie, I. Schaub, U. Karsten \& R. Jahn, 2016. Contribution towards a morphological and molecular taxonomic reference library of benthic marine diatoms from two Arctic fjords on Svalbard (Norway). Polar Biology 39: 1933-1956.

Sterrenburg, F. A. S., 1973. Extreme malformation and the notion of species. Microscopy 32: 314-318.

Straub, F., P. Derleth-Sartori \& B. Lods-Crozet, 2014. Les diatomées (algues silicatées), indicatrices de la qualité des cours d'eau vaudois: synthèse 2005 à 2013. Bulletin de la Société Vaudoise des Sciences Naturelles 94(1): 73-106.
Subba Rao, D. V. \& G. Wohlgeschaffen, 1990. Morphological variants of Nitzschia pungens Grunow f. multiseries Hasle. Botanica Marina 33: 545-550.

Szabó, K., K. T. Kiss, G. Taba \& É. Ács, 2005. Epiphytic diatoms of the Tisza River, Kisköre Reservoir and some oxbows of the Tisza River after the cyanide and heavy metal pollution in 2000. Acta Botanica Croatica 64(1): $1-46$.

Tabak, M., K. Scher, E. Hartog, U. Romling, K. R. Matthews, M. L. Chikindas \& S. Yaron, 2007. Effect of triclosan on Salmonella typhimurium at different growth stages and in biofilms. FEMS Microbiology Letters 267(2): 200-206.

Tabassum, A., H. S. Baig \& A. Rehman, 2015. Structural deformity in centric diatom species evidenced after Tasman Spirit Oil Spill. Pakistan Journal of Marine Sciences 24(1-2): 1-8.

Takano, H. \& K. Kikuchi, 1985. Anomalous cells of Nitzschia pungens Grunow found in eutrophic marine waters. Diatom 1: 18-20.

Tapia, P. M., 2008. Diatoms as bioindicators of pollution in the Mantaro River, Central Andes, Peru. International Journal of Environment and Health 2(1): 82-91.

Teng, S. T., C. P. Leaw, H. C. Lim \& P. T. Lim, 2013. The genus Pseudo-nitzschia (Bacillariophyceae) in Malaysia, including new records and a key to species inferred from morphology-based phylogeny. Botanica Marina 56(4): 375-398.

Tesson, B., S. J. L. Lerch \& M. Hildebrand, 2017. Characterization of a new protein family associated with the silica deposition vesicle membrane enables genetic manipulation of diatom silica. Scientific Reports 7: 13457.

Theriot, E. \& E. F. Stoermer, 1981. Some aspects of morphological variation in Stephanodiscus niagarae. Journal of Phycology 17: 64-72.

Theriot, E. \& E. F. Stoermer, 1984a. Principal component analysis of character variation in Stephanodiscus niagarae Ehrenb.: morphological variation related to lake trophic status. In Mann, D. G. (ed.), Proceedings of the Seventh International Diatom Symposium, Philadelphia, August 22-27, 1982. Otto Koeltz, Koenigstein: 97-111.

Theriot, E. \& E. F. Stoermer, 1984b. Principal component analysis of variation in Stephanodiscus rotula and S. niagarae. Systematic Botany 9(1): 53-59.

Theriot, E. \& E. F. Stoermer, 1984c. Principal component analysis of Stephanodiscus: observations on two new species from the Stephanodiscus niagarae complex. Bacillaria 7: 37-58.

Theriot, E., H. Håkansson \& E. F. Stoermer, 1988a. Morphometric analysis of Stephanodiscus alpinus (Bacillariophyceae) and its morphology as an indicator of lake trophic status. Phycologia 27(4): 485-493.

Theriot, E., Y.-Z. Qi, J.-R. Yang \& L.-Y. Ling, 1988b. Taxonomy of the diatom Stephanodiscus niagarae from a fossil deposit in Jingyu County, Jilin Province, China. Diatom Research 3(1): 159-167.

Thomas, W. H., J. T. Hollibaugh \& D. L. R. Seibert, 1980. Effects of heavy metals on the morphology of some marine phytoplankton. Phycologia 19(3): 202-209.

Tlili, A., N. Corcoll, B. Bonet, S. Morin, B. Montuelle, A. Bérard \& H. Guasch, 2011. In situ spatio-temporal changes in pollution-induced community tolerance to zinc in 
autotrophic and heterotrophic biofilm communities. Ecotoxicology 20: 1823-1839.

Tolotti, R., S. Consani, C. Carbone, G. Vagge, M. Capello \& L. Cutroneo, 2019. Benthic diatom community response to metal contamination from an abandoned $\mathrm{Cu}$ mine: case study of the Gromolo Torrent (Italy). Journal of Environmental Sciences 75: 233-246.

Tompkins, T. \& D. W. Blinn, 1976. The effect of mercury on the growth rate of Fragilaria crotonensis Kitton and Asterionella formosa Hass. Hydrobiologia 49(2): 111-116.

Torgan, L. C., A. A. H. Vieira, D. Giroldo \& C. B. dos Santos, 2006. Morphological irregularity and small cell size in Thalassiosira duostra maintained in culture. In Witkowski, A. (ed.), Proceedings of the Eighteenth International Diatom Symposium, Międzyzdroje, Poland, 2nd-7th September 2004. Biopress Limited, Bristol: 407-416.

Tornés, E., J.-R. Mor, L. Mandaric \& S. Sabater, 2018. Diatom responses to sewage inputs and hydrological alteration in Mediterranean streams. Environmental Pollution 238: 369-378.

Tudesque, L., G. Grenouillet, M. Gevrey, K. Khazraie \& S. Brosse, 2012. Influence of small-scale gold mining on French Guiana streams: are diatom assemblages valid disturbance sensors? Ecological Indicators 14(1): 100-106.

Urbánková, P., J. Kulichová \& C. Kilroy, 2015. Frustulia curvata and Frustulia paulii, two diatom species new to science. Diatom Research 30(1): 65-73.

Van de Vijver, B., 2008. Pinnularia obaesa sp. nov. and $P$. australorabenhorstii sp. nov., two new large Pinnularia (sect. Distantes) from the Antarctic King George Island (South Shetland Islands). Diatom Research 23(1): 221-232.

Vasiljević, B., S. B. Simić, M. Paunović, T. Zuliani, J. Krizmanić, V. Marković \& J. Tomović, 2017. Contribution to the improvement of diatom-based assessments of the ecological status of large rivers - the Sava River case study. Science of the Total Environment 605-606: 874-883.

Walsh, G. \& V. Wepener, 2009. The influence of land use on water quality and diatom community structures in urban and agriculturally stressed rivers. Water SA 35(5): 579-594.

Wang, Y., Mu W., Sun X., Lu X., Fan Y. \& Y. Liu (2020) Physiological response and removal ability of freshwater diatom Nitzschia palea to two organophosphorus pesticides. Chemistry and Ecology 36: 881-902.

Wetzel, C.E., I. Jüttner, S. Gurung \& L. Ector, 2019a. Analysis of the type material of Achnanthes minutissima var. macrocephala (Bacillariophyta) and description of two new small capitate Achnanthidium species from Europe and the Himalaya. Plant Ecology and Evolution 152(2): $340-350$.
Wetzel, C.E., B. Van de Vijver, S. Blanco \& L. Ector, 2019b. On some common and new cavum-bearing Planothidium (Bacillariophyta) species from freshwater. Fottea 19(1): 50-89.

Wilkinson, D. M., 1999. The disturbing history of intermediate disturbance. Oikos 84(1): 145-147.

Windler, M., D. Bova, A. Kryvenda, D. Straile, A. Gruber \& P. G. Kroth, 2014. Influence of bacteria on cell size development and morphology of cultivated diatoms. Phycological Research 62(4): 269-281.

Witkowski, A., F. Barka, D. G. Mann, C. Li, J. L. F. Weisenborn, M. P. Ashworth, K. J. Kurzydłowski, I. Zgłobicka \& S. Dobosz, 2014. A description of Biremis panamae sp. nov., a new diatom species from the marine littoral, with an account of the phylogenetic position of Biremis D.G. Mann et E.J. Cox (Bacillariophyceae). PLoS ONE 9(12): e114508.

Wojtal, A. Z., L. Ector, B. Van de Vijver, E. A. Morales, S. Blanco, J. Piatek, \& A. Smieja, 2011. The Achnanthidium minutissimum complex (Bacillariophyceae) in southern Poland. Algological Studies 136-137: 211-238.

Wood, R. J., S. M. Mitrovic, R. P. Lim, M. St. J. Warne, J. Dunlop \& B. J. Kefford, 2019. Benthic diatoms as indicators of herbicide toxicity in rivers - a new SPEcies At

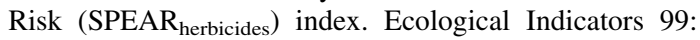
203-213.

Yang, J.-R. \& H. C. Duthie, 1993. Morphology and ultrastructure of teratological forms of the diatoms Stephanodiscus niagarae and S. parvus (Bacillariophyceae) from Hamilton Harbour (Lake Ontario, Canada). Hydrobiologia 269/270: 57-66.

You, Q., J. P. Kociolek, \& Q. Wang, 2015. The diatom genus Hantzschia (Bacillariophyta) in Xinjiang Province, China. Phytotaxa 197(1): 1-14.

Zalat, A., F. Welc, J. L. Marks, M. Chodyka \& Ł. Zbucki, 2018. Last two millennia water level changes of the Młynek Lake (northern Poland) inferred from diatoms and chrysophyte cysts record. Studia Quaternaria 35(2): 77-89.

Zhang, W., Y.-L. Li, J. P. Kociolek, R.-L. Zhang \& L.-Q. Wang, 2015. Oricymba tianmuensis sp. nov., a new cymbelloid species (Bacillariophyceae) from Tianmu Mountain in Zhejiang Province, China. Phytotaxa 236(3): 257-265.

Zimmermann, J., N. Abarca, N. Enk, O. Skibbe, W.-H. Kusber \& R. Jahn, 2014. Taxonomic reference libraries for environmental barcoding: a best practice example from diatom research. PLoS ONE 9(9): e108793.

Publisher's Note Springer Nature remains neutral with regard to jurisdictional claims in published maps and institutional affiliations. 